Prepared in cooperation with the Georgia Department of Natural Resources Environmental Protection Division

\title{
Geohydrology of the Aucilla-Suwannee- Ochlockonee River Basin, South-Central Georgia and Adjacent Parts of Florida
}

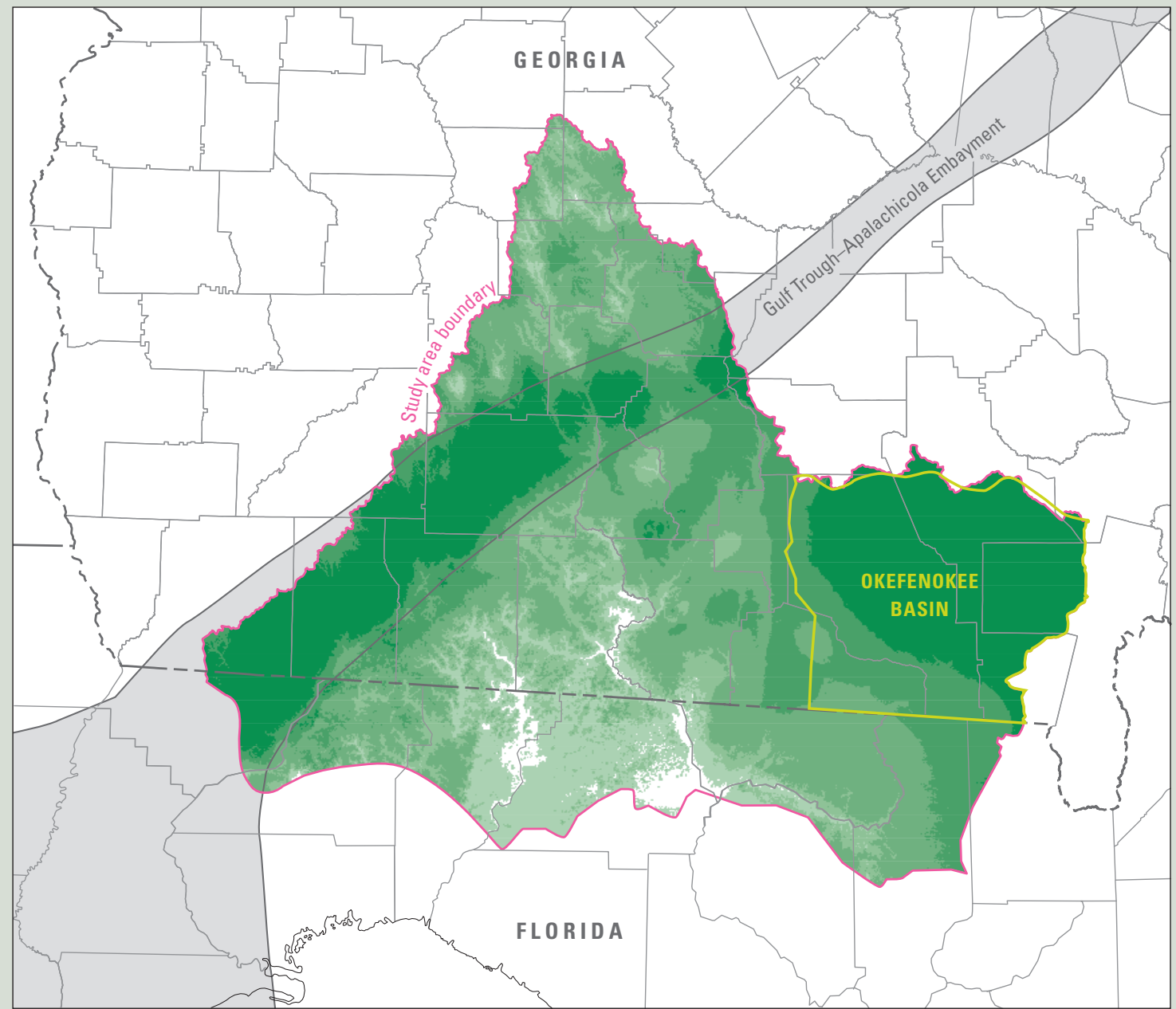

Scientific Investigations Report 2010-5072

U.S. Department of the Interior

U.S. Geological Survey 
Cover. See figure 15 of this report. 


\section{Geohydrology of the Aucilla-Suwannee- Ochlockonee River Basin, South-Central Georgia and Adjacent Parts of Florida}

By Lynn J. Torak, Jaime A. Painter, and Michael F. Peck

Prepared in cooperation with the

Georgia Department of Natural Resources

Environmental Protection Division

Scientific Investigations Report 2010-5072 


\title{
U.S. Department of the Interior \\ KEN SALAZAR, Secretary \\ U.S. Geological Survey \\ Marcia K. McNutt, Director
}

\section{U.S. Geological Survey, Reston, Virginia: 2010}

\begin{abstract}
For more information on the USGS - the Federal source for science about the Earth, its natural and living resources, natural hazards, and the environment, visit http://Www.usgs.gov or call 1-888-ASK-USGS

For an overview of USGS information products, including maps, imagery, and publications, visit $h$ ttp://www.usgs.gov/pubprod

To order this and other USGS information products, visit http://store.usgs.gov
\end{abstract}

Any use of trade, product, or firm names is for descriptive purposes only and does not imply endorsement by the U.S. Government.

Although this report is in the public domain, permission must be secured from the individual copyright owners to reproduce any copyrighted materials contained within this report.

Suggested citation:

Torak, L.J., Painter, J.A., and Peck, M.F., 2010, Geohydrology of the Aucilla-Suwannee-Ochlockonee River Basin, south-central Georgia and adjacent parts of Florida: U.S. Geological Survey Scientific Investigations Report $2010-5072,78$ p. 


\section{Contents}

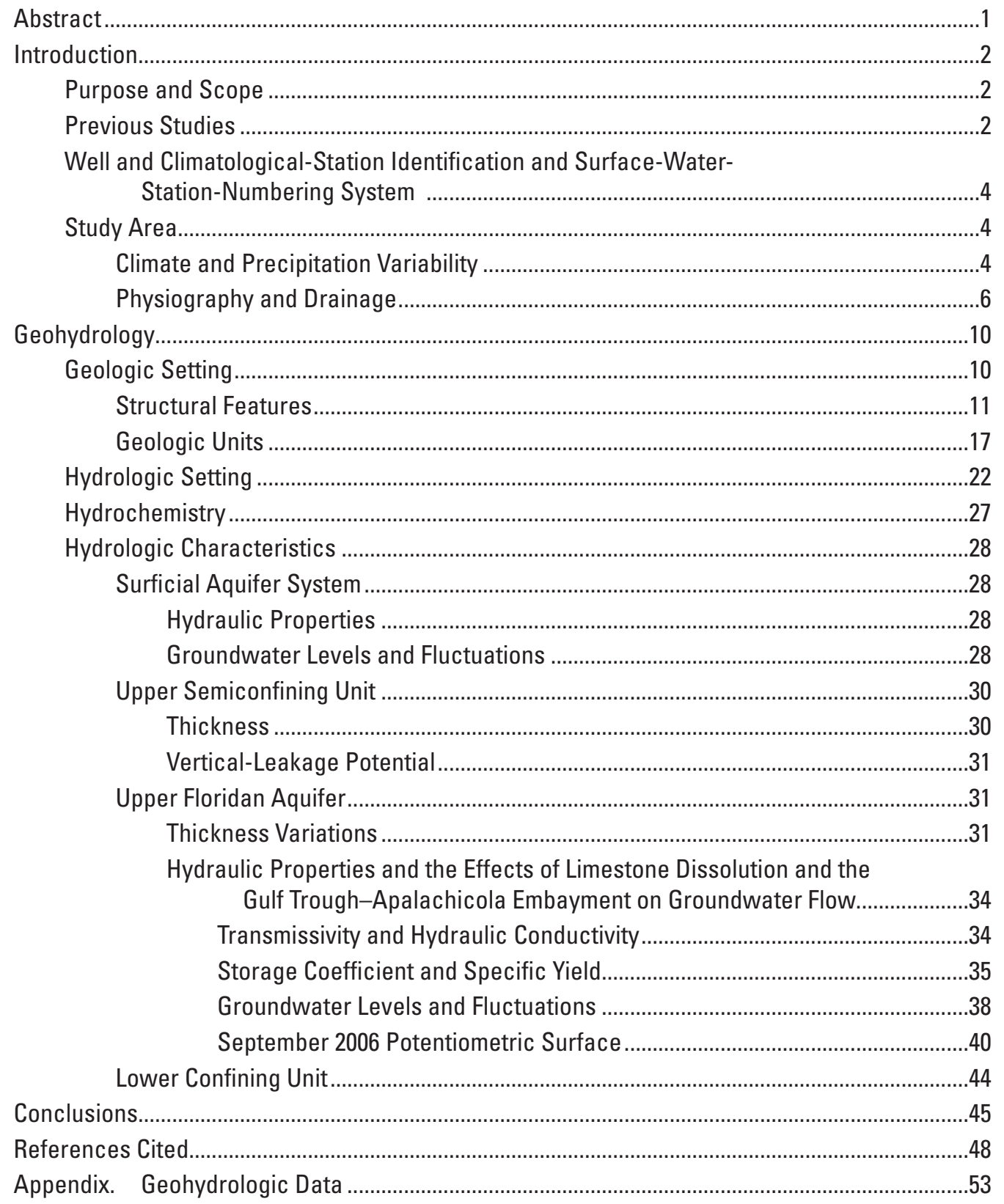




\section{Figures}

1. Map showing location of study area in the Aucilla-Suwannee-0chlockonee River Basin and lower Apalachicola-Chattahoochee-Flint River Basin, and of continuous-recorder observation wells and climatological and streamgaging stations in south-central Georgia and northwestern Florida.

2. Graphs showing period-of-record monthly mean, minimum, and maximum precipitation at climatological stations 92266, Cordele, Georgia, 1948-2005; 99186, Waycross, Georgia, 1930-2005; 84731, Lake City, Florida, 1931-2006; and 88758, Tallahassee, Florida, 1948-2005.

3. Map showing physiographic divisions in the Aucilla-Suwannee-Ochlockonee River Basin.

4. Correlation chart showing geologic and geohydrologic units and groundwater quality of the Upper Floridan aquifer and hydraulically connected sediments in the Aucilla-Suwannee-0chlockonee River Basin.

5-6. Maps showing-

5. Structural features affecting the Floridan aquifer system

6. Approximate location of the Gulf Trough-Apalachicola Embayment in the Aucilla-Suwannee-0chlockonee River Basin in southern Georgia and adjacent parts of Florida...

7. Geologic sections across northeastern Florida showing relations between geologic units and the Floridan aquifer system along $A-A^{\prime}$, from west of Lake City, Florida, to the Atlantic Ocean; and $B-B^{\prime}$, from Duval County, Florida, to Fernandina Beach, Florida

8. Geologic section across Colquitt County, Georgia, showing sediment thickening in the area of the Gulf Trough-Apalachicola Embayment.

9. Geologic section across Thomas County, Georgia, showing sediment thickening in the area of the Gulf Trough-Apalachicola Embayment

10. Geologic sections across northeastern Florida showing accumulation of Eocene sediment over the Peninsular Arch along $A-A^{\prime}$, from western Jefferson County, Florida, to Columbia County, Florida; and $B-B^{\prime}$, from Taylor County, Florida, near Gulf of Mexico, to Bradford County, Florida.

11. Geologic section across Crisp and Wilcox Counties, Georgia, showing reduction of Suwannee Limestone thickness to Flint River residuum.

12. Geologic section of Floridan aquifer system from Calhoun County, Georgia, southeast to Clay County, Florida, showing hydrostratigraphic relations and structure of sediments in the Aucilla-Suwannee-0chlockonee River Basin

13. Conceptual diagram of groundwater and surface-water flow in the interconnected stream-lake-aquifer flow system of the Aucilla-SuwanneeOchlockonee River Basin 
14-17. Maps showing-

14. Areal extent of surficial aquifer system in the Aucilla-SuwanneeOchlockonee River Basin

15. Overburden thickness and leakage potential of the upper semiconfining unit in the Aucilla-Suwannee-Ochlockonee River Basin

16. Altitude of the top of the Upper Floridian aquifer in the Aucilla-SuwanneeOchlockonee River Basin

17. Potentiometric surface of the surficial aquifer system in the Aucilla-

Suwannee-0chlockonee River Basin, September 2006

18. Groundwater hydrographs of wells 16M015, 16N006, 17L028, and 18K051, completed in the surficial aquifer system, for the period 2001-2007

19-21. Map showing-

19. Thickness of the Upper Floridan aquifer in the Aucilla-SuwanneeOchlockonee River Basin

20. Altitude of the base of the Upper Floridan aquifer in the AucillaSuwannee-Ochlockonee River Basin

21. Hydraulic properties of the Upper Floridan aquifer in the Aucilla-Suwannee-

Ochlockonee River Basin hydraulic conductivity and transmissivity.

22. Hydrograph showing seasonal groundwater-level fluctuation in well 15L020, Sylvester, Georgia, 1996-1999

23. Hydrographs showing daily mean depth to water level and period-of-record median daily groundwater level for wells 12F036, 1964-2008; 15L020, 1972-2008; 18H016, 1965-2008; 18K049, 1978-2008; 19E009, 1957-2008; 27E004, 1978-2008; and 27G003, 1982-2008.

24. Maps showing potentiometric surface of the Upper Floridan aquifer in southern Georgia and northern Florida, September 2006; and enlarged view of the potentiometric surface of the Upper Floridan aquifer in southern Georgia, September 2006, showing groundwater divide and flow directions.

\section{Tables}

1. Center-pivot irrigation in the lower Apalachicola-Chattahoochee-Flint River Basin during 1993 and 1999 in Georgia counties co-located along the basin divide with the Aucilla-Suwannee-Ochlockonee River Basin

2. Period-of-record monthly average precipitation at Lake City and Tallahassee, Florida, and at Cordele and Waycross, Georgia.

3. Precipitation for selected years and climatological stations located in the Aucilla-Suwannee-0chlokonee River Basin

A-1. Geohydrologic data for the Aucilla-Suwannee-0chlockonee River Basin 


\section{Conversion Factors and Datums}

\begin{tabular}{|c|c|c|}
\hline Multiply & By & To obtain \\
\hline \multicolumn{3}{|c|}{ Length } \\
\hline foot (ft) & 0.3048 & meter $(\mathrm{m})$ \\
\hline mile (mi) & 1.609 & kilometer $(\mathrm{km})$ \\
\hline \multicolumn{3}{|c|}{ Area } \\
\hline acre & 4,047 & square meter $\left(\mathrm{m}^{2}\right)$ \\
\hline acre & 0.4047 & hectare (ha) \\
\hline square mile $\left(\mathrm{mi}^{2}\right)$ & 259.0 & hectare (ha) \\
\hline square mile $\left(\mathrm{mi}^{2}\right)$ & 2.590 & square kilometer $\left(\mathrm{km}^{2}\right)$ \\
\hline \multicolumn{3}{|c|}{ Flow rate } \\
\hline foot per day (ft/d) & 0.3048 & meter per day $(\mathrm{m} / \mathrm{d})$ \\
\hline cubic foot per second $\left(\mathrm{ft}^{3} / \mathrm{s}\right)$ & 0.02832 & cubic meter per second $\left(\mathrm{m}^{3} / \mathrm{s}\right)$ \\
\hline gallon per minute (gal/min) & 0.06309 & liter per second $(\mathrm{L} / \mathrm{s})$ \\
\hline million gallons per day (Mgal/d) & 0.04381 & cubic meter per second $\left(\mathrm{m}^{3} / \mathrm{s}\right)$ \\
\hline \multicolumn{3}{|c|}{ Mass } \\
\hline ton, short $(2,000 \mathrm{lb})$ & 0.9072 & megagram $(\mathrm{Mg})$ \\
\hline \multicolumn{3}{|c|}{ Specific capacity } \\
\hline $\begin{array}{l}\text { gallon per minute per foot } \\
[(\mathrm{gal} / \mathrm{min}) / \mathrm{ft})]\end{array}$ & 0.2070 & $\begin{array}{l}\text { liter per second per meter } \\
{[(\mathrm{L} / \mathrm{s}) / \mathrm{m}]}\end{array}$ \\
\hline \multicolumn{3}{|c|}{ Hydraulic conductivity } \\
\hline foot per day (ft/d) & 0.3048 & meter per day $(\mathrm{m} / \mathrm{d})$ \\
\hline \multicolumn{3}{|c|}{ Hydraulic gradient } \\
\hline foot per mile (ft/mi) & 0.1894 & meter per kilometer $(\mathrm{m} / \mathrm{km})$ \\
\hline \multicolumn{3}{|c|}{ Transmissivity* } \\
\hline foot squared per day $\left(\mathrm{ft}^{2} / \mathrm{d}\right)$ & 0.09290 & meter squared per day $\left(\mathrm{m}^{2} / \mathrm{d}\right)$ \\
\hline
\end{tabular}

Temperature in degrees Celsius $\left({ }^{\circ} \mathrm{C}\right)$ may be converted to degrees Fahrenheit $\left({ }^{\circ} \mathrm{F}\right)$ as follows:

$$
{ }^{\circ} \mathrm{F}=\left(1.8 \times{ }^{\circ} \mathrm{C}\right)+32
$$

Temperature in degrees Fahrenheit $\left({ }^{\circ} \mathrm{F}\right)$ may be converted to degrees Celsius $\left({ }^{\circ} \mathrm{C}\right)$ as follows:

$$
{ }^{\circ} \mathrm{C}=\left({ }^{\circ} \mathrm{F}-32\right) / 1.8
$$

Vertical coordinate information is referenced to the North American Vertical Datum of 1988 (NAVD 88).

Horizontal coordinate information is referenced to the North American Datum of 1983 (NAD 83).

Altitude, as used in this report, refers to distance above the vertical datum.

*Transmissivity: The standard unit for transmissivity is cubic foot per day per square foot times foot of aquifer thickness $\left[\left(\mathrm{ft}^{3} / \mathrm{d}\right) / \mathrm{ft}^{2}\right] \mathrm{ft}$. In this report, the mathematically reduced form, foot squared per day $\left(\mathrm{ft}^{2} / \mathrm{d}\right)$, is used for convenience.

Concentrations of chemical constituents in water are given either in milligrams per liter (mg/L) or micrograms per liter $(\mu \mathrm{g} / \mathrm{L})$. 


\title{
Geohydrology of the Aucilla-Suwannee- Ochlockonee River Basin, South-Central Georgia and Adjacent Parts of Florida
}

\author{
By Lynn J. Torak, Jaime A. Painter, and Michael F. Peck
}

\section{Abstract}

Major streams and tributaries located in the AucillaSuwannee-Ochlockonee (ASO) River Basin of south-central Georgia and adjacent parts of Florida drain about 8,000 square miles of a layered sequence of clastic and carbonate sediments and carbonate Coastal Plain sediments consisting of the surficial aquifer system, upper semiconfining unit, Upper Floridan aquifer, and lower confining unit. Streams either flow directly on late-middle Eocene to Oligocene karst limestone or carve a dendritic drainage pattern into overlying Miocene to Holocene sand, silt, and clay, facilitating water exchange and hydraulic connection with geohydrologic units.

Geologic structures operating in the ASO River Basin through time control sedimentation and influence geohydrology and water exchange between geohydrologic units and surface water. More than 300 feet ( $\mathrm{ft}$ ) of clastic sediments overlie the Upper Floridan aquifer in the Gulf TroughApalachicola Embayment, a broad area extending from the southwest to the northeast through the center of the basin. These clastic sediments limit hydraulic connection and water exchange between the Upper Floridan aquifer, the surficial aquifer system, and surface water. Accumulation of more than $350 \mathrm{ft}$ of low-permeability sediments in the Southeast Georgia Embayment and Suwannee Strait hydraulically isolates the Upper Floridan aquifer from land-surface hydrologic processes in the Okefenokee Basin physiographic district. Burial of limestone beneath thick clastic overburden in these areas virtually eliminates karst processes, resulting in low aquifer hydraulic conductivity and storage coefficient despite an aquifer thickness of more than $900 \mathrm{ft}$. Conversely, uplift and faulting associated with regional tectonics and the northern extension of the Peninsular Arch caused thinning and erosion of clastic sediments overlying the Upper Floridan aquifer southeast of the Gulf Trough-Apalachicola Embayment near the Florida-Georgia State line. Limestone dissolution in Brooks and Lowndes Counties, Ga., create karst features that enhance water-transmitting and storage properties of the Upper Floridan aquifer, promoting groundwater recharge and water exchange between the aquifer, land surface, and surface water.

Structural control of groundwater flow and hydraulic properties combine with climatic effects and increased hydrologic stress from agricultural pumpage to yield unprecedented groundwater-level decline in the northwestern and central parts of the ASO River Basin. Hydrographs from continuous-record observation wells in these regions document declining groundwater levels, indicating diminished water-resource potential of the Upper Floridan aquifer through time. More than $24 \mathrm{ft}$ of groundwater-level decline occurred along the basin's northwestern boundary with the lower Apalachicola-Chattahoochee-Flint River Basin, lowering hydraulic gradients that provide the potential for groundwater flow into the ASO River Basin and southeastward across the Gulf Trough-Apalachicola Embayment region. Slow-moving groundwater across the trough-embayment region coupled with downward-vertical flow from upper to lower limestone units composing the Upper Floridan aquifer resulted in 40-50 ft of groundwater-level decline since 1969 in southeastern Colquitt County. Multi-year episodes of dry climatic conditions during the 1980 s through the early 2000 s contributed to seasonal and long-term groundwater-level decline by reducing recharge to the Upper Floridan aquifer and increasing hydrologic stress by agricultural pumpage. Unprecedented and continued groundwater-level decline since 1969 caused $40-50 \mathrm{ft}$ of aquifer dewatering in southeastern Colquitt County that reduced aquifer transmissivity and the ability to supply groundwater to wells, resulting in depletion of the groundwater resource. 


\section{Introduction}

Episodic-drought conditions and increased pumpage since the mid-1970s have caused unprecedented groundwaterlevel decline in the Upper Floridan aquifer in much of the roughly 8,000-square-mile $\left(\mathrm{mi}^{2}\right)$ Aucilla-SuwanneeOchlockonee (ASO) River Basin (fig. 1). During 2007, record-low groundwater levels occurred in Charlton, Cook, Tift, Ware, and Worth Counties. The groundwater level in Lowndes County declined nearly 25 feet (ft) during the first 10 months of 2006, after recovering nearly that much and holding stable since 2003. An eastward shift in location of municipal groundwater withdrawal at Cairo, Ga., reversed a $35-\mathrm{ft}$ declining groundwater-level trend that occurred during 1966-1973, although groundwater-level fluctuations of as much as $20 \mathrm{ft}$ occurred in multiyear cycles since that time.

Since the early 1990s, increased center-pivot irrigation along the basin divide with the neighboring ApalachicolaChattahoochee-Flint (ACF) River Basin (Litts and others, 2001) has intercepted groundwater that, prior to irrigation pumpage, was available to recharge the ASO River Basin as regional (interbasin) groundwater flow. Pumpage increases along the boundary of the ASO and ACF River Basins have accelerated groundwater-level declines in the Upper Floridan aquifer and reduced the hydraulic gradient, thus reducing the amount of regional groundwater flow (interbasin flow) to the south and east into the ASO River Basin (Torak and Painter, 2006). Long-term groundwater-level decline in the Upper Floridan aquifer has the potential to reduce springflow, decrease groundwater discharge to streams (baseflow), and diminish interbasin flow from the north and west, threatening the ability of the basin's water resources to meet current and future demand.

As a result of these concerns, the U.S. Geological Survey (USGS), in cooperation with the State of Georgia, Department of Natural Resources, Environmental Protection Division (GA-EPD), began a study in September 2006 to acquire, compile, and interpret geohydrologic information in the ASO River Basin. Study results would enable development of science-based, cause-and-effect relations between groundwater withdrawal for agricultural, municipal, industrial, and drinking-water purposes and groundwater-level and streamflow trends. Hydrologic relations developed from this study would enable evaluation of emerging resource issues related to groundwater-level and streamflow declines, such as aquatic-habitat degradation and potential local or regional groundwater shortages resulting from excessive groundwater withdrawal and dry climatic conditions.

\section{Purpose and Scope}

This report describes the geohydrologic investigation of the ASO River Basin performed primarily in Georgia; however, adjacent areas of the panhandle of northwestern
Florida have been included as needed (fig. 1). Investigative results described herein provide a framework for evaluation of groundwater level and streamflow decline in the ASO basin, as jointly developed by the GA-EPD and USGS. Objectives of this investigation and report accomplish the following tasks,

1. Describe the lithology and hydraulic properties of the Upper Floridan aquifer and hydraulically connected geologic units that would enable assessment of water exchange between the Upper Floridan aquifer and other geohydrologic units and surface water.

2. Develop a hydrogeologic framework and conceptual model for evaluating agricultural pumpage and groundwater and surface-water exchange between the Upper Floridan aquifer and other geohydrologic units connected to surface water.

3. Present an overview of 2006 groundwater-level and streamflow conditions.

4. Explain hydrologic concepts of the groundwater and surface-water exchange mechanisms that control causal relations between groundwater pumpage in the Upper Floridan aquifer, climatic variations, groundwater-level decline, reductions in streamflow and springflow, and changes in interbasin flow.

\section{Previous Studies}

Early investigations provided general descriptions of the geology and groundwater in the area (McCallie, 1898, 1908; Stephenson and Veatch, 1915; Cooke, 1943; and Herrick and Vorhis, 1963). Cooke (1943) mapped the geology of the coastal plain of Georgia, and MacNeil (1947) mapped Tertiary and Quaternary formations in the study area. Wait (1960) published water-chemistry analyses of selected wells in the basin. Herrick (1961) compiled detailed lithologic and paleontological logs of wells throughout the Georgia Coastal Plain.

Previous hydrologic investigations in Georgia have neither included the entire area of the ASO River Basin nor evaluated causal relations between groundwater pumpage and declining groundwater level, streamflow, and springflow. Studies performed for the National Water-Quality Assessment (NAWQA) Program, Georgia-Florida Coastal Plain Drainages study unit (U.S. Geological Survey, 2006), included evaluation of nutrient loads of several major rivers, including the main rivers of the ASO River Basin in Georgia and Florida; however, none of these studies compiled geologic and hydrologic data into a comprehensive geohydrologic framework in the study area. A NAWQA Program study by Pittman and Berndt (2003) focused on water-quality issues related to herbicide degradation in the surficial aquifer and streams located in the upper part of the basin.

Priest (2004) evaluated the groundwater contribution to streamflow in the coastal area of Georgia and adjacent Florida and South Carolina; however, the study area encompassed 
only part of the Suwannee River Basin and excluded the Aucilla and Ochlockonee Rivers to the west. Falls and others (2005) investigated the hydrogeology of the Lower Floridan aquifer in 24 coastal counties in Georgia and adjacent Florida and South Carolina, which included only the extreme eastern part of the ASO River Basin. Payne and others (2005) compiled additional geologic information for a larger study area than that of Falls and others (2005) still excluding the western parts of the ASO River Basin. Studies by Torak and Painter (2006) and Jones and Torak (2006), investigated stream-aquifer relations in the neighboring ACF River Basin to the north and west, and only marginally investigated the geohydrology of the Ochlockonee River and upper Suwannee River Basins inasmuch as it affected groundwater flow in the western basin of interest.

McConnell and Hacke (1993) and Plummer and others $(1998 \mathrm{a}, \mathrm{b})$ performed hydrologic studies of the water chemistry of the karst area in the Upper Floridan aquifer at Valdosta, Ga. Katz and others (1995a,b, 1997), Katz (1998), and Crandall and others (1999) investigated hydrochemistry of stream-lake-aquifer interaction in karst areas of northern Florida. Studies describing the geochemistry and groundwater quality of the Upper Floridan aquifer include Sever (1965), Sprinkle (1989), and Katz (1992).

A geohydrologic investigation by Torak and Painter (2006) and simulation of groundwater and surface-water exchange by Jones and Torak (2006) indicate that irrigation pumpage in outcrop and recharge areas of the Upper Floridan aquifer in the lower ACF River Basin intercepts groundwater that once was available to recharge the ASO River Basin as regional (interbasin) groundwater flow. The geohydrologic investigation by Torak and Painter (2006) indicates that reduced interbasin flow from irrigation pumpage in the ACF River Basin limits groundwater availability and development potential in the ASO River Basin and can reduce baseflow of streams located along the basin's northwestern boundary and interior. Lithologic descriptions given in the study by Torak and Painter (2006) indicate that large variations in hydraulic conductivity of the Upper Floridan aquifer exist at regional and local scales that could alter the amount of groundwater and surface-water exchange between the aquifer and surface water within short distances.

Previous investigations provided water-use information in the ASO River Basin and documented increases in rates of groundwater withdrawal for irrigation, industry, and public supply. Thomson and others (1956) noted increases in statewide irrigation following the 1954 drought. Carter and Johnson (1974) compiled statewide estimates of irrigated acres based on a 1969 U.S. Census Bureau national summary of agriculture and compiled water-use estimates according to Area Planning and Development Commission regions. Pierce and others (1984) documented large increases in agricultural irrigation in southwestern Georgia during the 1970s, differentiated groundwater- and surface-water-irrigation withdrawal, and identified locations of center-pivot irrigation systems in a
"High Irrigation Water Use Zone" during 1980 that included the ACF and ASO River Basins. Harrison and Tyson (1999) and Harrison (2001) reported results of the Georgia Irrigation Survey that identified steadily increasing trends in agricultural water-use statewide and increased use of center-pivot irrigation. Turlington and others (1987), Fanning and others (1992), and Fanning $(1997,2003)$ compiled water-use data by county and type of use, and provided summaries of water use, by county, for 1985, 1990, 1995, and 2000, respectively. Litts and others (2001) reported significant increases in centerpivot-irrigation systems during the 1990s within and along the boundary between the ASO and lower ACF River Basins (table 1). Unfortunately, the investigation by Litts and others (2001) only reported irrigated acreage and acreage change associated with the lower ACF River Basin, although seven Georgia counties are located partially in both basins.

Geologic nomenclature used herein is consistent with previous geologic and hydrologic investigations performed in the study area and adjacent regions to the north and west, and described in reports by Sever $(1964,1965)$, Sever and Herrick (1967), Miller (1986), Torak and McDowell (1996), Torak and others (1996, 2006), Albertson and Torak (2002), Mosner (2002), and Jones and Torak $(2004,2006)$. Consistent nomenclature with that used in the neighboring ACF River Basin and recent investigations, referenced above, promotes increased understanding of the role of geologic units during assessment of water resources in the ASO River Basin and emphasizes regional importance of these units northward and westward to the outcrop areas. Alternate naming conventions of geologic units are presented and cited for reference where appropriate.

Table 1. Center-pivot irrigation in the lower ApalachicolaChattahoochee-Flint River Basin during 1993 and 1999 in Georgia counties co-located along the basin divide with the Aucilla-Suwannee-0chlockonee River Basin (see fig. 1 for county locations; modified from Litts and others, 2001).

[-, not applicable]

\begin{tabular}{lrrrr}
\hline \multirow{2}{*}{ County } & \multicolumn{2}{c}{$\begin{array}{c}\text { Center-pivot irrigation } \\
\text { (acres) }\end{array}$} & $\begin{array}{c}\text { 1993 to 1999 } \\
\text { increase } \\
\text { (acres) }\end{array}$ & $\begin{array}{c}\text { Percent } \\
\text { increase }\end{array}$ \\
\cline { 2 - 4 } Crisp & \multicolumn{1}{c}{$\mathbf{1 9 9 3}$} & $\mathbf{1 9 9 9}$ & 8,056 & 207 \\
Decatur & 3,895 & 11,951 & 11,709 & 24 \\
Dooly & 67,870 & 59,579 & 5,503 & 79 \\
Grady & 2,828 & 3,254 & 426 & 15 \\
Mitchell & 47,610 & 58,425 & 10,815 & 23 \\
Turner & 211 & 1,384 & 1,173 & 556 \\
Worth & 9,552 & 15,675 & 6,123 & 64 \\
Total & $\mathbf{1 1 8 , 9 5 0}$ & $\mathbf{1 6 2 , 7 5 5}$ & $\mathbf{4 3 , 8 0 5}$ & - \\
\hline
\end{tabular}

${ }^{a}$ Acreage located in Apalachicola-Chattahoochee-Flint River Basin only. 


\section{Well and Climatological-Station Identification and Surface-Water-Station-Numbering System}

A system based on USGS topographic maps identifies wells in Georgia. Each 71/2-minute topographic quadrangle map in Georgia has been given a number and letter designation beginning at the southwestern corner of the State. Numbers increase eastward through 39, letters advance northward through "Z," then double-letter designations "AA" through "PP" are used. The letters "I," and "O" are not used. Wells inventoried in each quadrangle are numbered sequentially beginning with " 1. ." Thus, the 49th well inventoried in the Tifton East quadrangle (designated 18K) is designated 18K049 (fig. 1). Wells in Florida are numbered with a four-digit numerical code that is assigned by the Northwest Florida Water Management District (Christopher J. Richards, Northwest Florida Water Management District, Havana, Fla., written commun., April 2000).

Climatological stations are given a name that corresponds to the nearest city, town, or locality; figures and letters following the name indicate the distance in miles and compass direction from the post office or town community center, such as Albany 3 SE (National Oceanic and Atmospheric Administration, 2002), located 3 miles (mi) southeast of the town center. Additionally, climatological stations are "identified by a six-digit number that constitutes the National Weather Service (NWS) Cooperative Station Network. The first two digits designate a state or territory code. The last four digits are assigned to stations within a state in general accordance with the alphabetical order of the station name. A station in this network, as designated by a single Cooperative Station Identifier, can be one site or a series of sites whose locations fall within $2 \mathrm{mi}$ horizontal or $100 \mathrm{ft}$ vertical distance. There are exceptions to this rule, with 'climatic compatibility,' as determined by the NWS field manager, being the overriding factor" (National Oceanic and Atmospheric Administration, 2008). For example, station number 092266 corresponds to the station "CORDELE," located in Cordele, Ga. (fig. 1). The leading " 0 " of the state or territory code has been omitted in this report.

Partial- and continuous-record surface-water stations are given an identification number, which is assigned in "downstream order" (Stokes and others, 1990). No distinction is made between partial-record stations and other stations; therefore, the number for a partial-record station indicates downstream-order position in a list made up of both types of stations. The complete number for each station, such as 02314500 , includes a 2-digit part number " 02 " plus a sixdigit downstream-order number, "314500."

\section{Study Area}

The study area is located in the Coastal Plain Physiographic Province of south-central Georgia and adjacent Florida, and consists mainly of the land area and geologic units contributing to the headwaters of the Aucilla, Suwannee, and Ochlockonee Rivers, and similar headwater drainage to the St. Marks River (fig. 1). Drainage basins of the Alapaha, Little, and Withlacoochee Rivers, and tributaries to the Suwannee River, are contained wholly within the study area. The Alapaha, Little, and Withlacoochee Rivers and their tributaries either flow directly over the limestone aquifer on a gentle, seaward-sloping karst plain, or incise sandy to clayey sediments overlying the limestone, carving a dendritic drainage pattern in the landscape.

\section{Climate and Precipitation Variability}

Long summers and mild winters characterize the climate of the ASO River Basin, which ranges from temperate in the northwestern part to humid subtropical in the southern and southeastern parts. Proximity of the basin to the Gulf of Mexico and Atlantic Ocean influences the seasonal variation of temperature and precipitation. Mean-annual temperatures for the climatic period 1971-2000 vary about 3 degrees Fahrenheit $\left({ }^{\circ} \mathrm{F}\right)$, from about $69^{\circ} \mathrm{F}$ in the southern and southeastern parts of the basin near the Gulf of Mexico and Atlantic Ocean (Tallahassee and Lake City, Florida, respectively; fig. 1) to about $66^{\circ} \mathrm{F}$ inland in the northwestern and eastern parts of the basin (Cordele and Waycross, Ga., respectively) (Southeast Regional Climate Center, 2008a, b, c, d). Winterlow temperatures during December and January vary from the mid- to upper- $30 \mathrm{~s}{ }^{\circ} \mathrm{F}$ in the northwestern and eastern parts of the basin, to the low- to mid- $40 \mathrm{~s}^{\circ} \mathrm{F}$ to the south and southeast. Summer-high temperatures occur during June, July, and August and vary from the low- $90 \mathrm{~s}^{\circ} \mathrm{F}$ in the northwestern and eastern parts of the basin, to the mid- to upper- $90 \mathrm{~s}^{\circ} \mathrm{F}$ to the south and southeast. Occasional freezing temperatures occur throughout the study area during fall through spring. Temperatures approaching $100^{\circ} \mathrm{F}$ and above generally occur during late-spring through early-fall within much of the study area except to the south, where summertime cloudiness and thunderstorms limit high temperatures to the low- $90 \mathrm{~s}^{\circ} \mathrm{F}$.

Precipitation varies geographically and temporally in the ASO River Basin according to the seasonal influence of weather patterns that bring humid subtropical and maritime air northward from the Gulf of Mexico and Atlantic Ocean and that move continental air masses into the basin from the north and west. Long-term records indicate nearly an 18 -inch variation in total annual precipitation, from about 62.5 inches in Tallahassee, Fla., to the south, to about 44.9 inches in Cordele, Ga., to the northwest (table 2) (Southeast Regional Climate Center, 2008a, c). Summertime southwesterly winds bring tropical moisture inland from the Gulf of Mexico causing higher precipitation in the southern part of the study area (near Tallahassee, Fla.) than to the northwest (near Cordele, Ga.). Coastal storms from the Atlantic Ocean increase precipitation along the eastern part of the study area (near Waycross, Ga.). The southeastern part of the study area receives precipitation from the remains of coastal and gulf storms that move inland 

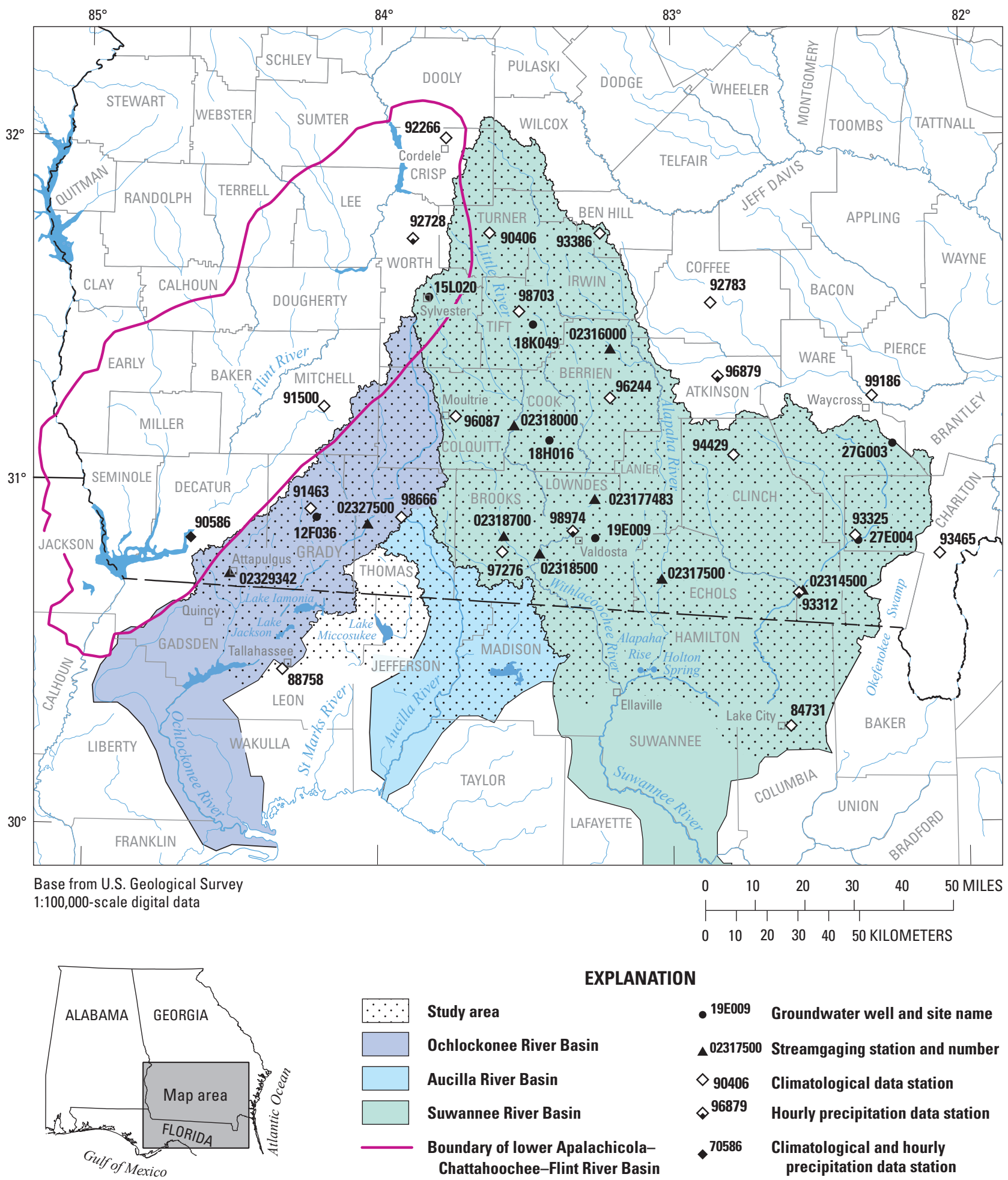

\section{EXPLANATION}

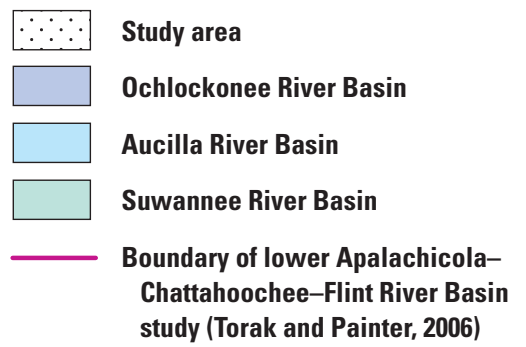

- 19E009 Groundwater well and site name

$\triangle 02317500$ Streamgaging station and number

$\diamond 90406$ Climatological data station

\$6879 Hourly precipitation data station

\0586 Climatological and hourly precipitation data station

Figure 1. Location of study area in the Aucilla-Suwannee-Ochlockonee River Basin and lower Apalachicola-ChattahoocheeFlint River Basin, and of continuous-recorder observation wells and climatological and streamgaging stations in south-central Georgia and northwestern Florida. 
Table 2. Period-of-record monthly average precipitation at Lake City and Tallahassee, Florida, and at Cordele and Waycross, Georgia (Southeast Regional Climate Center 2008a, b,c, d; see fig. 1 for location).

\begin{tabular}{|c|c|c|c|c|}
\hline \multirow[b]{2}{*}{ Month } & \multicolumn{4}{|c|}{ Period-of-record average precipitation, in inches } \\
\hline & $\begin{array}{l}\text { Cordele, } \\
\text { Georgia (92266) } \\
\text { 1948-2006 }\end{array}$ & $\begin{array}{c}\text { Waycross } 4 \text { NE, } \\
\text { Georgia (99186) } \\
\text { 1930-2005 }\end{array}$ & $\begin{array}{l}\text { Lake City } 2 \mathrm{E} \\
\text { Florida (84731) } \\
\text { 1931-2006 }\end{array}$ & $\begin{array}{l}\text { Tallahassee, WSO AP, } \\
\text { Florida (88758) } \\
\text { 1948-2005 }\end{array}$ \\
\hline January & 4.10 & 3.89 & 3.67 & 4.42 \\
\hline February & 4.20 & 3.57 & 3.73 & 4.81 \\
\hline March & 4.98 & 4.49 & 4.50 & 5.98 \\
\hline April & 3.37 & 3.21 & 3.15 & 3.72 \\
\hline May & 3.14 & 3.40 & 3.50 & 4.35 \\
\hline June & 4.21 & 5.63 & 6.58 & 7.14 \\
\hline July & 5.00 & 6.56 & 7.27 & 8.50 \\
\hline August & 3.89 & 5.95 & 7.12 & 7.21 \\
\hline September & 3.83 & 4.68 & 5.48 & 5.69 \\
\hline October & 1.97 & 2.84 & 2.95 & 3.16 \\
\hline November & 2.74 & 2.32 & 2.24 & 3.36 \\
\hline December & 3.54 & 3.10 & 3.01 & 4.11 \\
\hline Annual & 44.86 & 49.63 & 53.19 & 62.46 \\
\hline
\end{tabular}

to the northern-peninsular and eastern-panhandle region near Lake City, Fla. Continental storms associated with frontal passages bring precipitation to the central and northwestern parts of the basin during late fall through early spring. Annual precipitation is fairly uniformly distributed throughout the year; however, slightly less precipitation occurs during April and May and during October through December than during the remaining months of the year.

Variations in monthly mean, minimum, and maximum precipitation measured at National Oceanic and Atmospheric Administration climatological stations that encompass the ASO River Basin (Cordele and Waycross, Ga., and Lake City and Tallahassee, Fla.) give an indication of the susceptibility of the basin to extremely dry or wet conditions (fig. 2). Monthly precipitation records at Cordele and Waycross, Ga., and at Lake City and Tallahassee, Florida, indicate dry conditions from September through May. Each of these stations recorded no precipitation for at least 1 month during the fall, and Cordele, Ga., listed no precipitation during October, November, and December during the period of record 1948-2006. June, July, and August have the highest minimum precipitation amounts of the year, most likely the result of summer thunderstorms and tropical storms, such as hurricanes.

The highest maximum precipitation recorded at Cordele and Waycross, Ga., and at Lake City and Tallahassee, Florida, occurred during September, which also can be one of the driest months (fig. 2). All four weather stations listed a maximum precipitation during September of at least 18 inches, perhaps the result of tropical storms. One such storm deposited nearly 8 inches of rain at Lake City, Florida, and nearly 5 inches of rain at Waycross, Ga., on September 7, 2004, which contributed to the September period-of-record maximum precipitation at each station (Southeast Regional Climate Center, 2008b, d). Most other months recorded maximum precipitation in the 10-15-inch range, with the exception of Cordele, Ga., where the maximum precipitation of 7-8 inches occurred during February, April, October, and November. The southern and southeastern parts of the basin (Tallahassee and Lake City, Florida) historically have recorded monthly maximum precipitation in excess of 10 inches year-round, with two minor exceptions occurring at Lake City, Florida, during February (about 9.9 inches) and November (about 9 inches) during the period of record 1931-2006.

\section{Physiography and Drainage}

Three distinct regions of the Coastal Plain Physiographic Province define unique landforms and surface drainage in the study area: a region of dissected hills and sand-hill ridges; an area of low relief that decreases to the southeast and contains numerous swamps; and a relatively flat, coastal-sediment region with karst limestone at or near land surface. The hilly region - termed the Tifton Upland District in Georgia and the Tallahassee Hills District (Puri and Vernon, 1964) and Northern Highlands (Cooke, 1939) in Florida - contains headwater drainage to the Alapaha, Aucilla, Ochlockonee, and Withlacoochee Rivers (fig. 3). The Tifton Upland is bounded to the west by the Solution Escarpment (MacNeil, 1947) and to the east by the eastern drainage divide of the Alapaha River. The swampy area of low relief to the east of the Tifton Upland and Tallahassee Hills is termed the Okefenokee Basin District (Clark and Zisa, 1976) and is drained by the Suwannee River. 


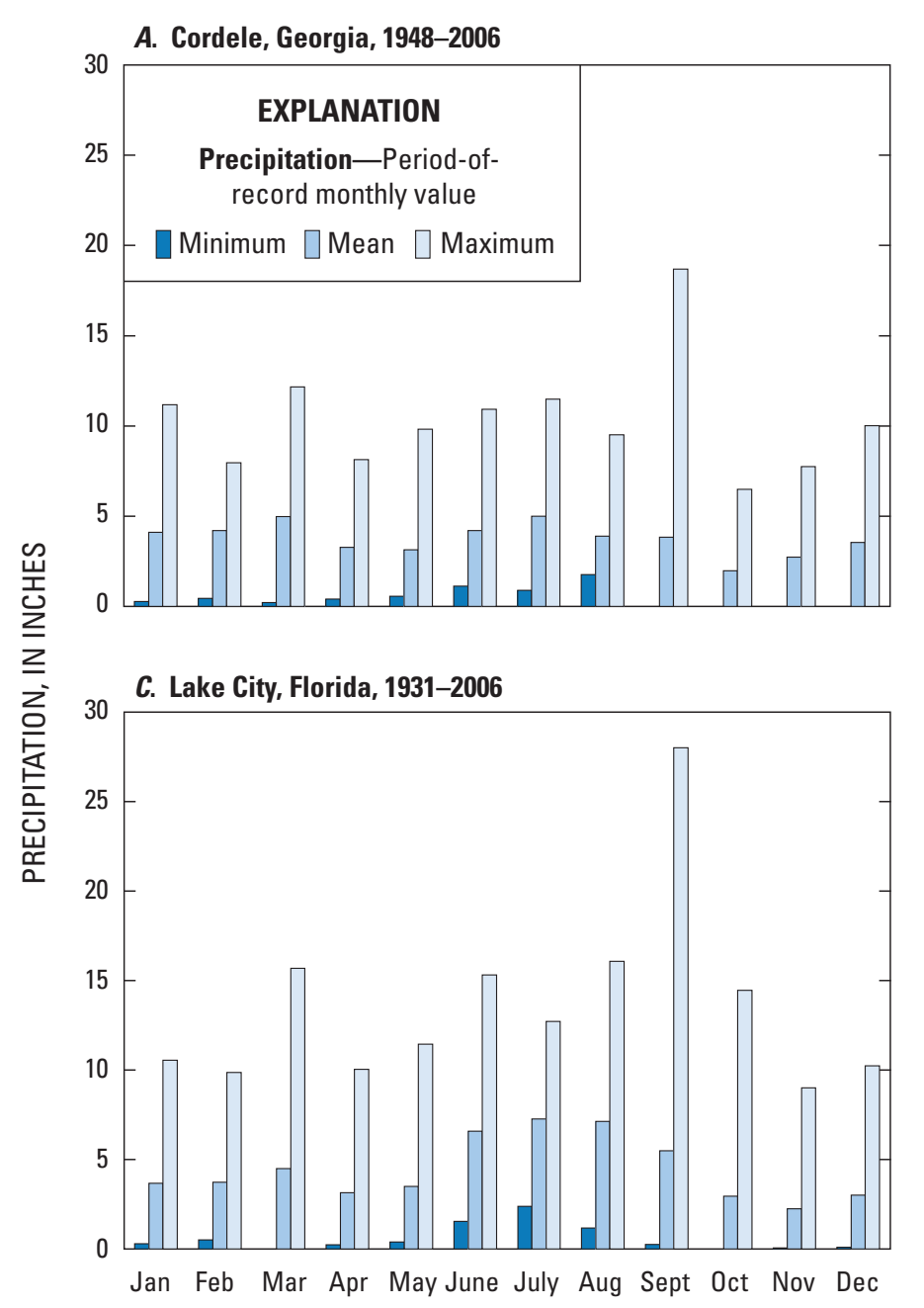

B. Waycross, Georgia, 1930-2005

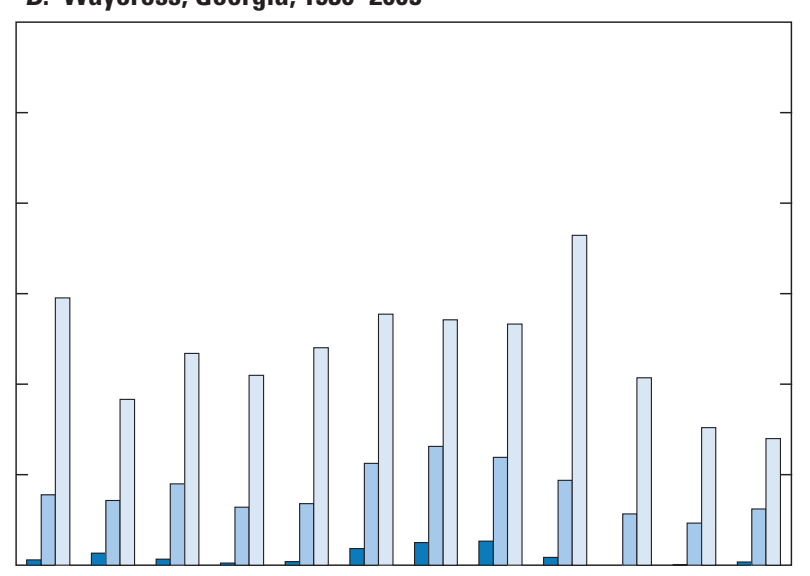

D. Tallahassee, Florida, 1948-2005

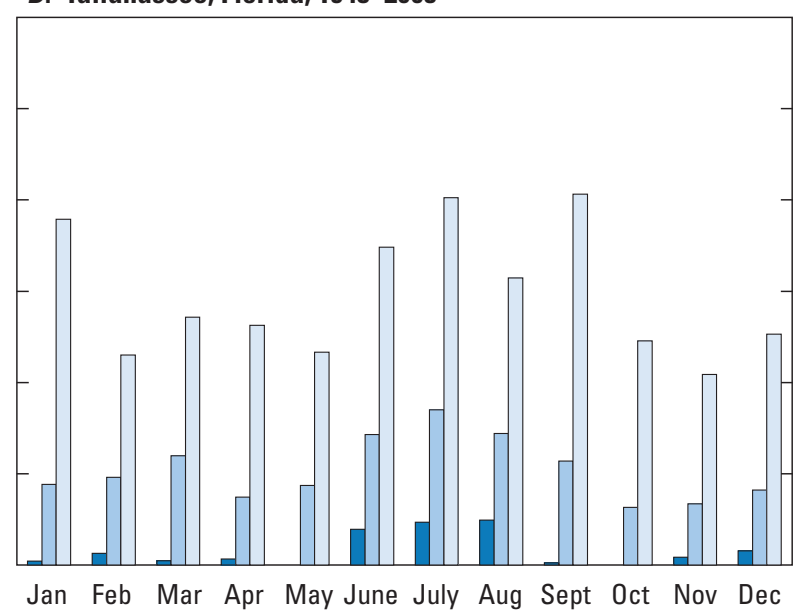

Figure 2. Period-of-record monthly mean, minimum, and maximum precipitation at climatological stations $(A) 92266$, Cordele, Georgia, 1948-2005; (B) 99186, Waycross, Georgia, 1930-2005; (C) 84731, Lake City, Florida, 1931-2006; and (D) 88758, Tallahassee, Florida, 1948-2005 (Southeast Regional Climate Center, 2008a, b, c, d).

The Cody Scarp, called the "most persistent topographic break in the state" by Puri and Vernon (1964), denotes a transition between the Tallahassee Hills and Northern Highlands and the relatively flat coastal region of the Gulf Coastal Lowlands, which frames the southern study area boundary. Above the escarpment, the thin, clastic cover is commonly breached by erosion, both from above by streams and from below by subsidence sinkholes. This erosional dissection has broadened the escarpment into a transition zone. Where the cover is breached, virtually all surface drainage flowing off the highlands disappears underground; numerous springs occur a short distance below the escarpment. Several of these, such as the Alapaha Rise, constitute discrete resurgences apparently connected to the sinking point by continuous conduits, although this has not been absolutely documented. The outflow is frequently turbid, reddish-brown, river-type water; however, there is also a substantial groundwater component to this flow (Ceryak, 1977).
The Tifton Upland, Tallahassee Hills, and Northern Highlands are parts of a nearly continuous series of topographically high uplands containing gently rolling hills with broad rounded summits situated between the low-lying Dougherty Plain to the northwest, Gulf Coastal Lowlands to the south, and Okefenokee Basin to the east (fig. 3). The upland regions appear to be disconnected remnants of a once-continuous residual highland (Yon, 1966). Stream valleys divide the Northern Highlands into a series of local geomorphic subzones. The Tallahassee Hills was the name proposed by Cooke (1939) for the region bounded by the Georgia State line to the north, coastal terraces to the south, the Withlacoochee River to the east, and the Apalachicola River to the west (Rupert, 1990). The hilly regions contain resistant clayey sands, silts, and clays (Arthur and Rupert, 1989), which slope gently to the southeast. 

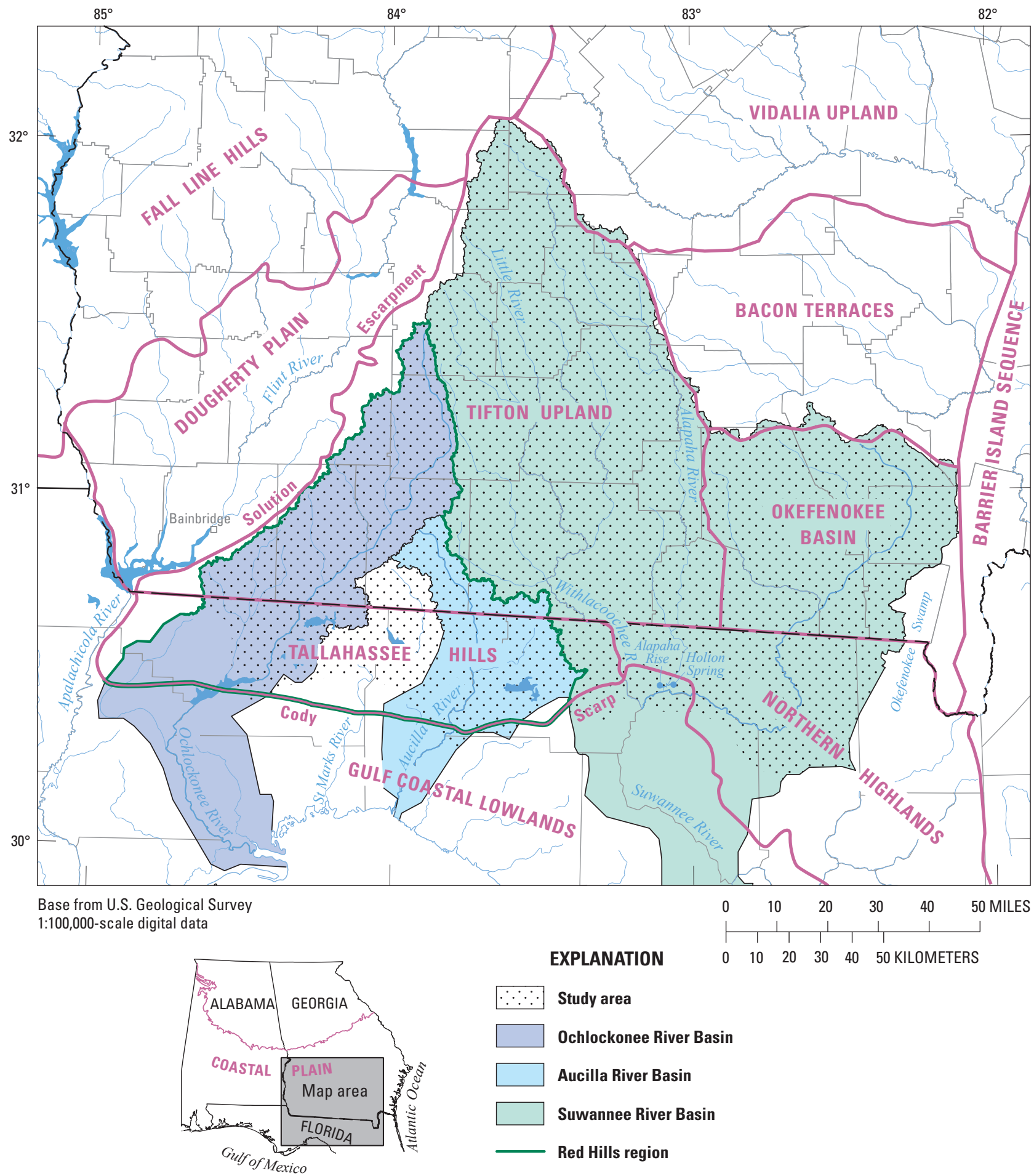

Study area

Ochlockonee River Basin

Aucilla River Basin

Suwannee River Basin

Red Hills region

Figure 3. Physiographic divisions in the Aucilla-Suwannee-0chlockonee River Basin (modified from Cooke, 1939; and Clark and Zisa, 1976). 
The Tifton Upland is a distinct cuesta that begins just west of the study area with a prominent escarpment (the Solution Escarpment) nearly $150 \mathrm{ft}$ high overlooking the Flint River (Fenneman, 1938) (fig. 3). Land-surface altitude in the Tifton Upland ranges from about $480 \mathrm{ft}$ in the north to about $150 \mathrm{ft}$ to the southeast, which is indicative of the regional dip of underlying sediments (Clark and Zisa, 1976). Land-surface altitude in the Florida counterpart to the Tifton Upland, the Tallahassee Hills, ranges from about $330 \mathrm{ft}$ near the FloridaGeorgia State line to about $100 \mathrm{ft}$ in the southern part of the region. The high- altitude areas of the Tifton Upland contain solution features, some of which are abundant in a broad eastwest strip along the Florida-Georgia State line (Fenneman, 1938). Dendritic drainage of many surface streams dissects the hills and forms deeply incised valleys and ravines (Rupert, 1990) in the otherwise broad, flat plain.

The Tifton Upland and Tallahassee Hills contain the 927- $\mathrm{mi}^{2}$ Red Hills region, which encompasses the Aucilla and Ochlokonee River Basins in Florida and Georgia and is bounded on the south by the Cody Scarp (Cox and others, 2001) (fig. 3). The Red Hills region comprises part of a belt of Eocene hilly terrain that extends across Alabama and Mississippi and contains ravines and clay-capped ridges (Schwaner and Mount, 1970; Davis, 1996b) that, in Florida and Georgia, drain to the Aucilla and Ochlockonee Rivers. Sandy loam soil supports sandhill vegetation that covers ridge tops composed of uneroded clay (Schwaner and Mount, 1970). Ravines form, however, from selective clay erosion. Surface runoff and dissolution subsidence control topography, and small karst depressions hold temporary ponds (Davis, 1996a).

The Red Hills region of the Aucilla and Ochlockonee River Basins provides habitat to rare flora and fauna. This region may contain the only known localities in Florida and Georgia for the salamander Phaeognathus hubrichti, which has been located in equivalent hilly regions in Alabama (Schwaner and Mount, 1970). One of the largest remaining populations of federally endangered red-cockaded woodpeckers (Picoides borealis) is present in the Red Hills region, as well as some of the best examples of old-growth longleaf pine (Pinus palustris) remaining in the southeastern United States (Cox and others, 2001).

The Aucilla River is a distinctive blackwater stream that rises in central Thomas County, Ga., and drains marshes and lakes before flowing over karst limestone east of Tallahassee, Fla., where it disappears in sinkholes located along the Cody Scarp, only to reappear downstream as springflow (1,000 Friends of Florida, 2006). Blackwater streams have a naturally dark appearance or are tea-colored due to dissolved organic matter carried by the stream (Wakulla County Tourist Development Council, 2007).
The Ochlockonee River rises just south of Sylvester, Ga., and flows southward about $300 \mathrm{mi}$ over clayey sediments of the Tifton Upland and Tallahassee Hills to an estuary before emptying to the Gulf of Mexico (fig. 1). Transported sediment and organic matter give the Ochlockonee River a distinct yellow color. The organic matter nourishes numerous species of fish and shellfish, which sustain recreational and commercial fishing in the estuary and Gulf of Mexico. The Ochlockonee River is State-designated as Outstanding Florida Water and is a well-known canoe trail (Wakulla County Tourist Development Council, 2007).

The Okefenokee Basin District (fig. 3) contains numerous swamps and low relief that decreases to the southeast (Clark and Zisa, 1976). Land-surface altitude ranges from about $240 \mathrm{ft}$ in the northwest on Pliocene-Pleistocene deposits to about $75 \mathrm{ft}$ to the southeast on Pleistocene deposits; relief varies from about $50 \mathrm{ft}$ to about $5 \mathrm{ft}$. The swamps range in size from a few hundred square feet to the $660-\mathrm{mi}^{2}$ Okefenokee Swamp. The Suwannee River rises in the Okefenokee Basin District of southeastern Georgia, where a series of southeasterly flowing tributaries joins the main channel and drains the Okefenokee Swamp as the river flows southwest into northcentral Florida (fig. 1).

The Suwannee River receives major tributary flow from the Alapaha and Withlacoochee Rivers, which rise on the Tifton Upland and join the Suwannee River in the northern panhandle of Florida near Ellaville (fig. 1). The Alapaha River flows through a mature karst terrain of numerous sinkholes, stream sinks, and springs on the Tifton Upland and Northern Highlands before disappearing into several large sinkholes (Raulston and others, 1998). The subterranean river flows through solution channels in the limestone for about 19 mi before emerging at two springs-Alapaha Rise and Holton Spring — and before joining the Suwannee River. The Suwannee River contains the second largest streamflow in Florida, after the Apalachicola River in northwestern Florida (Raulston and others, 1998). In Florida, a few northwesterly flowing tributaries drain the Northern Highlands before the Suwannee River crosses the Cody Scarp and flows onto the Gulf Coastal Lowlands.

The Gulf Coastal Lowlands (fig. 3) is a sandy, flat, seaward-sloping feature shaped mostly by wave and current activity from Pleistocene high sea-level stands (Arthur and Rupert, 1989). Land surface in the lowlands contains relic Pleistocene marine bars, terraces, spits, and sandbar dunes (Leitman and others, 1984) with limestone at or near the surface. Streams entering the Gulf Coastal Lowlands from the Northern Highlands disappear into the limestone aquifer at the Cody Scarp, only to reappear downstream as springflow. 


\section{Geohydrology}

Geologic and hydrologic settings within the ASO River Basin define distinct lithologic and fluid-flow characteristics that control groundwater movement and interaction with surface water. The Upper Floridan aquifer and overlying and underlying semiconfining units contain geologic formations, the hydraulic properties of which combine with human-induced stress to influence water-resource availability, groundwater and surface-water exchange, and development potential.

The following sections describe geologic and hydrologic characteristics of the Upper Floridan aquifer, and overlying and underlying semiconfining units, that improve current understanding of the lithology and hydraulic properties of the aquifer and hydraulically connected geologic units. Such an understanding enables conceptualization of water exchange among the Upper Floridan aquifer, hydraulically connected geologic units, and surface water in the ASO River Basin and promotes development of causal relations between groundwater pumpage in the Upper Floridan aquifer and groundwater-level decline and reductions in streamflow and springflow.

\section{Geologic Setting}

A thick Jurassic to Holocene sequence of sedimentary rocks and unconsolidated to semiconsolidated sediments underlies the Coastal Plain Physiographic Province in the ASO River Basin and forms a tilted wedge of permeable and semipermeable layers that thickens seaward from a featheredge in outcrop areas to the northwest to more than $20,000 \mathrm{ft}$ in southern Alabama and Florida (Miller, 1986). Miller (1986) identified the section of mostly Paleocene to early Miocene carbonate and clastic geologic units, variously hydraulically connected, as the Floridan aquifer system of the southeastern United States. The Eocene to Holocene sequence of geologic units defines the Upper Floridan aquifer and hydraulically connected sediments that contribute to groundwater and surface-water exchange in the study area (fig. 4). Middle Miocene to Holocene clastic sediments overlie the Floridan aquifer system nearly everywhere except where erosion has removed poorly consolidated sediments and exposed carbonates at land surface. Dissolution by infiltrating precipitation forms local to regional karst features where carbonates presently lie at or near land surface, or where now-buried carbonates previously were exposed at land surface on the paleo landscape.
Figure 4. Geologic and geohydrologic units and groundwater quality of the Upper Floridan aquifer and hydraulically connected sediments in the AucillaSuwannee-Ochlockonee River Basin (modified from Miller, 1986; Rupert, 1990; and Torak and Painter, 2006).

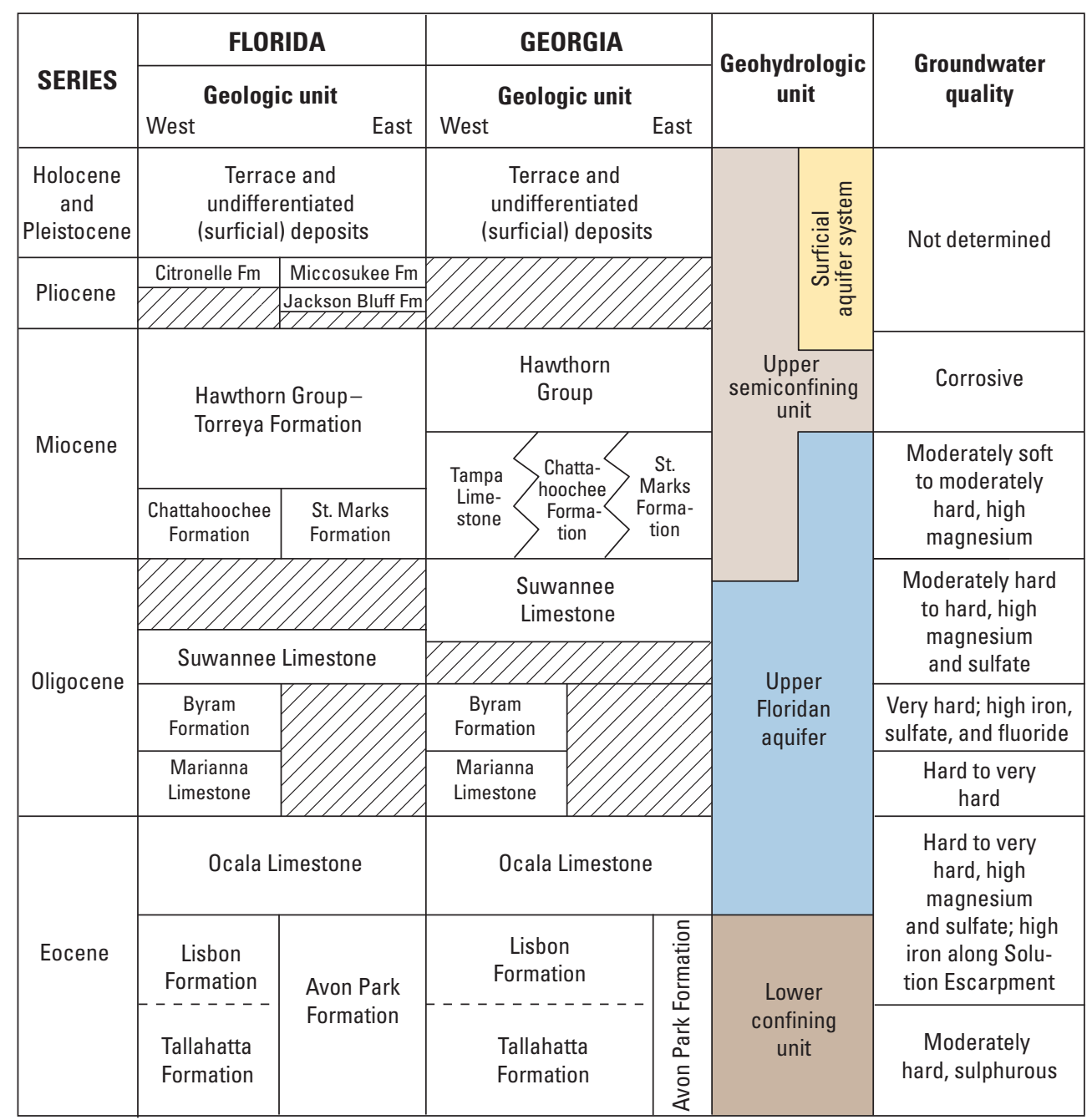




\section{Structural Features}

Local tectonics in the ASO River Basin associated with altered crystalline basement rocks, differential compaction, and solution and collapse of limestone affected the accumulation and lithology of Coastal Plain sediments that constitute the aquifers and confining units of the Floridan aquifer system. Upwarping during early Mesozoic to late Cretaceous produced by compressional tectonics associated with the seaward extension of the Appalachian and (or) Ouachita structural belts (Chen, 1965) formed the Peninsular Arch in north-central Florida, which dominated sedimentation in the southeastern part of the study area (Miller, 1986) (fig. 5). Clastic and carbonate sediments accumulated on the flanks of the Peninsular Arch to the northeast, north, northwest, and west since at least the Early Cretaceous in depositional features termed, respectively, the Southeast Georgia (or Savannah) Embayment, Suwannee Strait, Gulf Trough (fig. 6), and Apalachicola (or Southwest Georgia) Embayment, (Miller, 1986). The Southeast Georgia Embayment represents a shallow east-to-northeast-plunging syncline that subsided at a moderate rate allowing an accumulation of clastic and carbonate sediments (Miller, 1986) (fig. 7). In contrast, a nearly continuous sequence of late Jurassic clastic sediments fill the southwest-plunging syncline of the Apalachicola Embayment and Gulf Trough (Miller, 1986), followed by thickening of Oligocene to Miocene sediments (figs. 8 and 9).

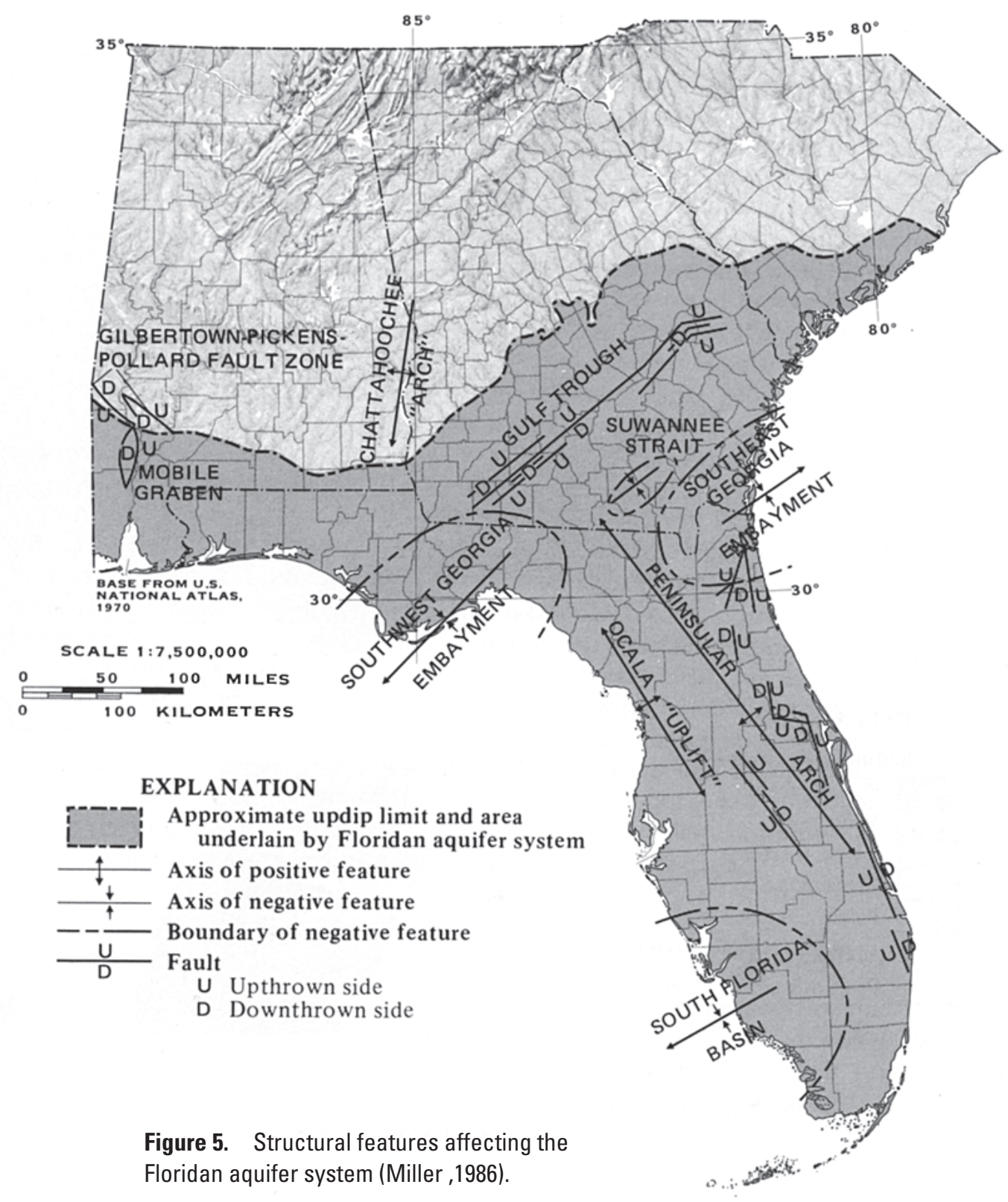


Kellam and Gorday (1990) describe the Gulf TroughApalachicola Embayment as part of a subsurface paleomarine channel system in the Georgia Coastal Plain, with the former (Gulf Trough) a northeastward extension of the latter. Declining sea level restricted circulation within this channel, allowing deposition of a thick accumulation of fine-grained material (Davis, 1996a). Miller (1986) describes the Gulf Trough as a series of boundary faults to grabens that position low water-bearing clastic sediments opposite limestone of the Floridan aquifer system. The low watertransmitting ability of these features allows them to be discussed in this report as a single geohydrologic entity termed the Gulf Trough-Apalachicola Embayment (fig. 6).
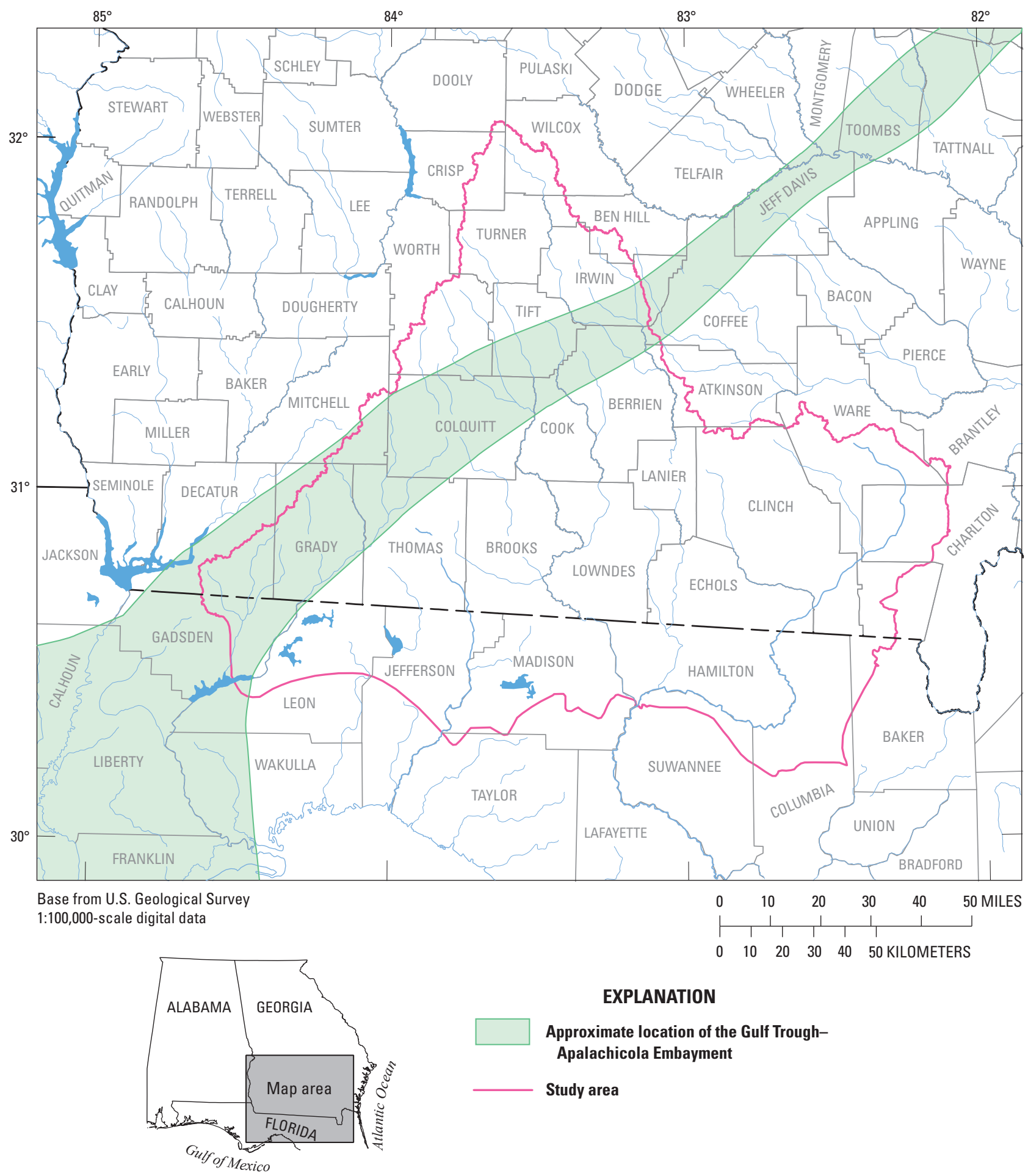

\section{EXPLANATION}

Approximate location of the Gulf TroughApalachicola Embayment

Study area

Figure 6. Approximate location of the Gulf Trough-Apalachicola Embayment in the Aucilla-Suwannee-0chlockonee River Basin in southern Georgia and adjacent parts of Florida (modified from Kellam and Gorday, 1990; Davis, 1996a). 


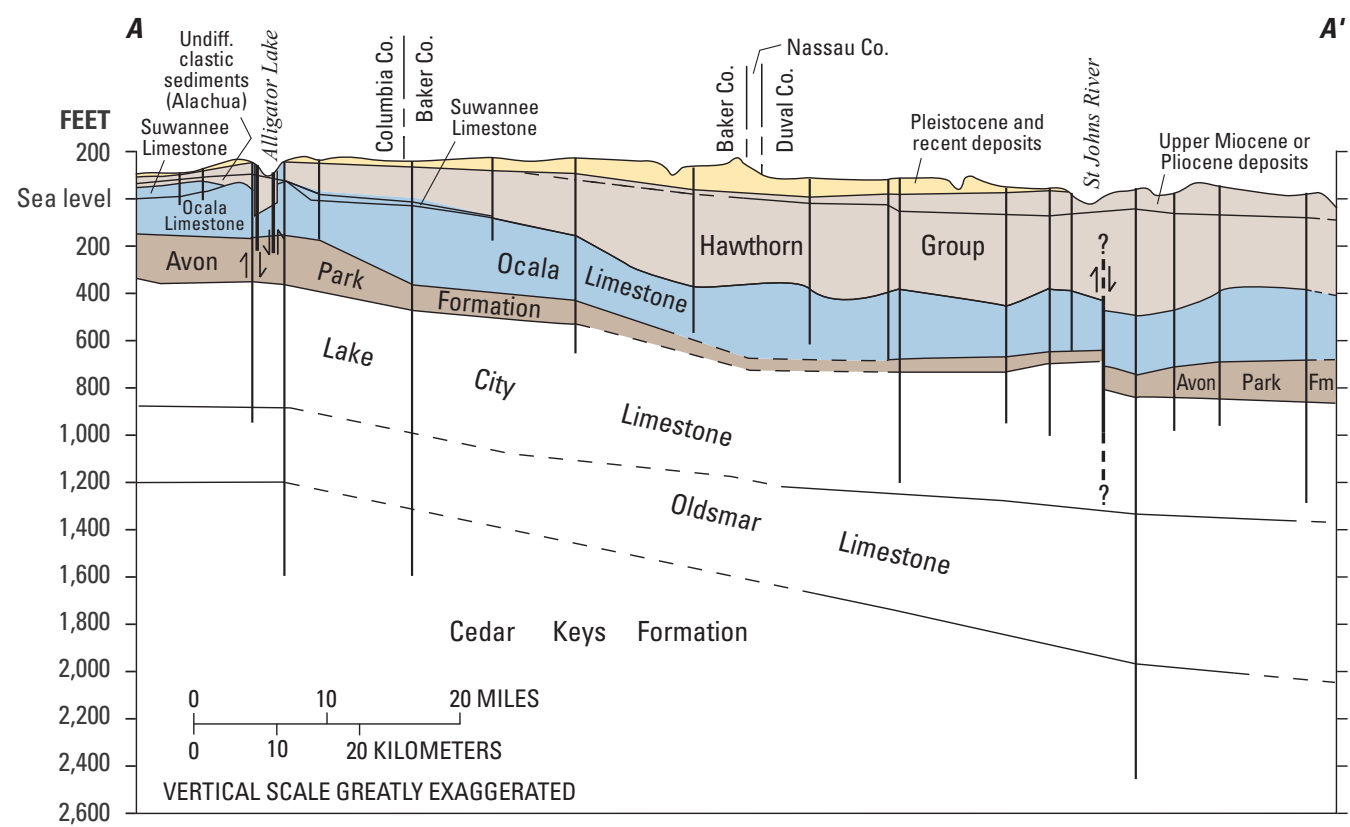

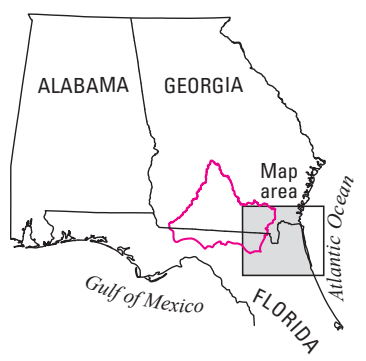

MAP

Approximate boundary of Gulf Trough-Apalachicola Embayment

$\downarrow \quad$ Approximate axis of Southeast Georgia Embayment

\section{- Study area boundary}

$\boldsymbol{A}-\boldsymbol{A}^{\prime}$ Line of section

- Control point

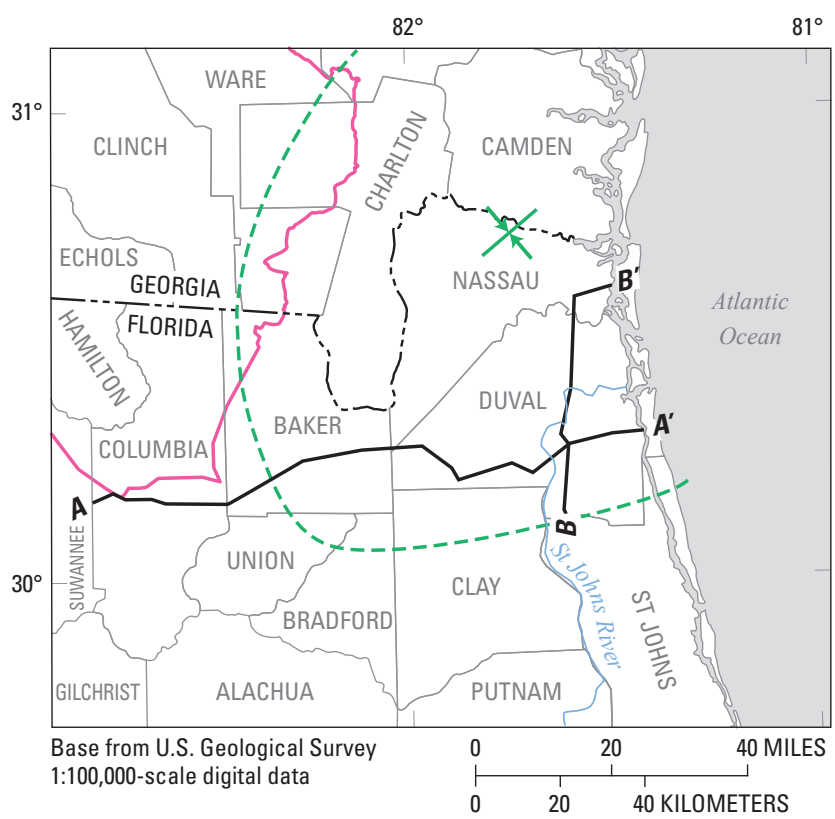

EXPLANATION

CROSS SECTION

Hydrologic unit

Surficial aquifer system

Upper semiconfining unit

Upper Floridan aquifer

Lower confining unit

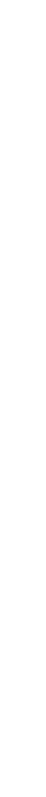



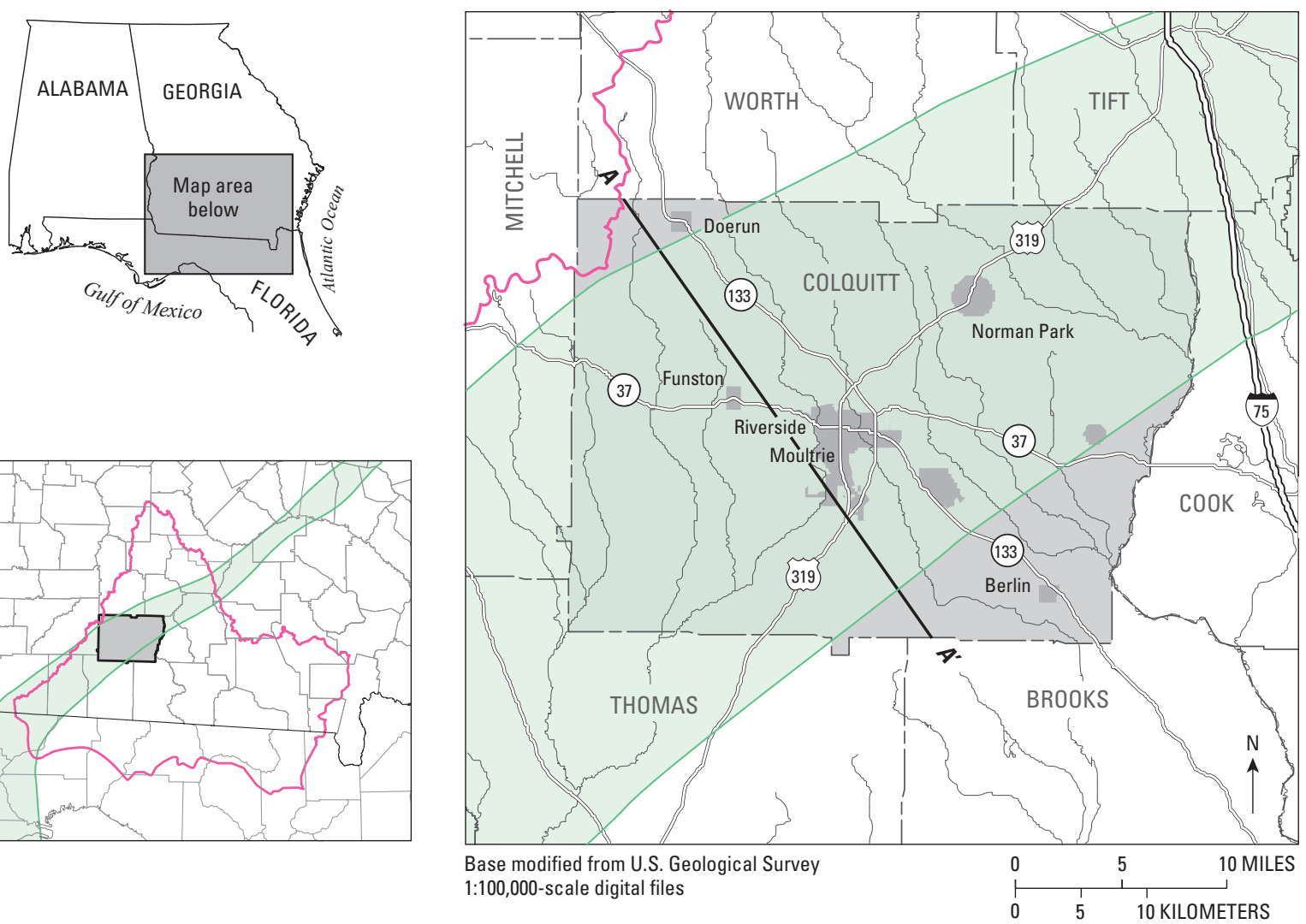

\section{EXPLANATION}

MAP

Approximate location of Gulf Trough-Apalachicola Embayment

- Study area boundary

$A-A^{\prime}$ Line of section

\section{CROSS SECTION}

Hydrologic unit

Surficial aquifer system

Upper semiconfining unit

Upper Floridan aquifer

Lower confining unit

Geologic contact-

Dashed where inferred

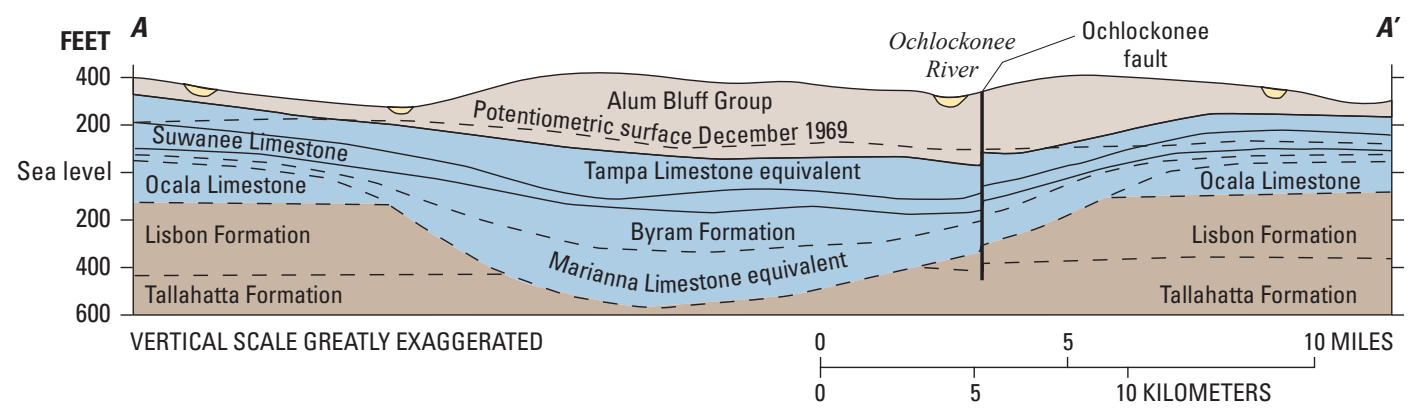

Figure 8. Geologic section across Colquitt County, Georgia, showing sediment thickening in the area of the Gulf Trough-Apalachicola Embayment (modified from Zimmerman, 1977). 

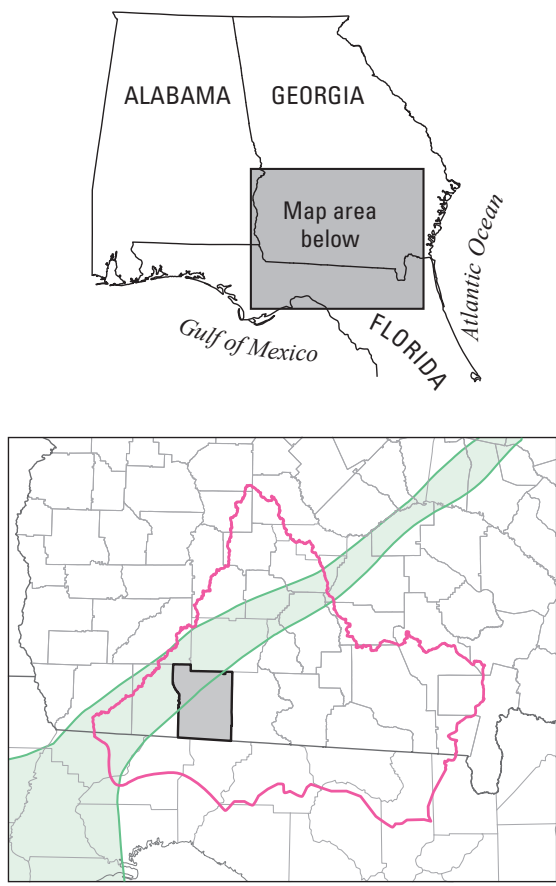

EXPLANATION

MAP

Approximate location of Gulf Trough-Apalachicola Embayment

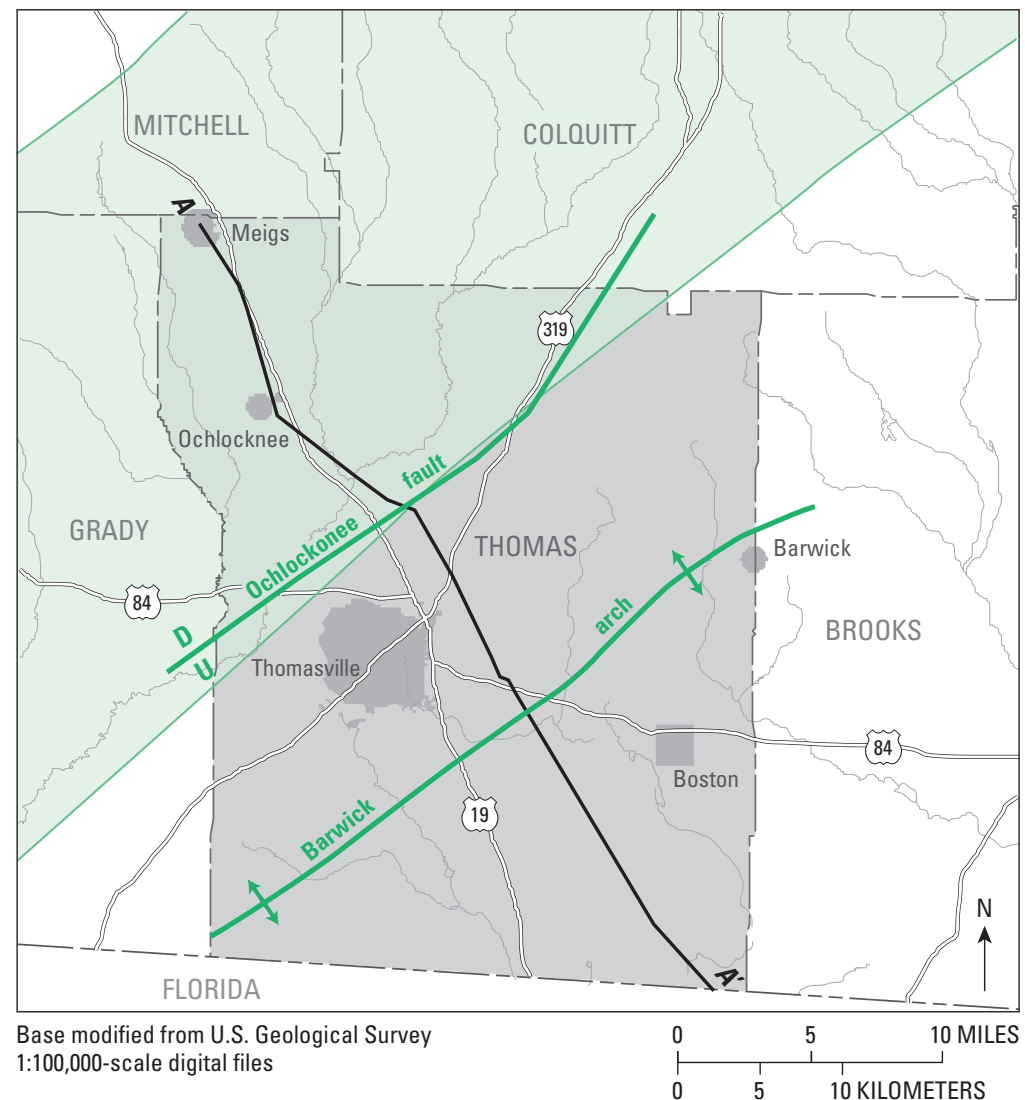

\section{Ochlockonee fault-Relative \\ fault movement; U, upthrown; \\ D, downthrown}

Study area boundary

\section{$A-A^{\prime}$ Line of section}

\section{CROSS SECTION}

Hydrologic unit

Surficial aquifer system

Upper semiconfining unit

Upper Floridan aquifer

Geologic contact-

Dashed where inferred

Jir Fault-Short dash

where inferred

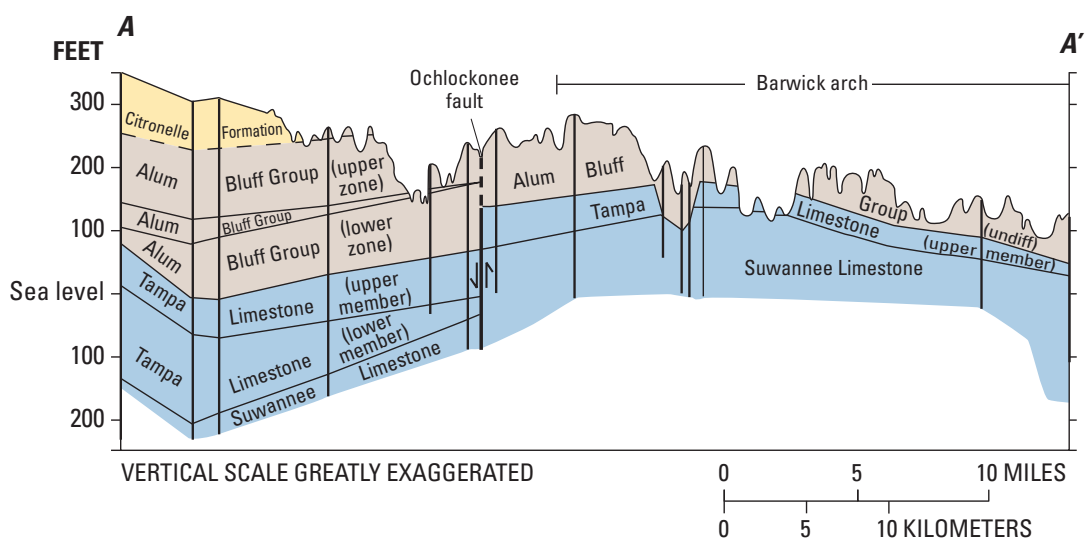

Figure 9. Geologic section across Thomas County, Georgia, showing sediment thickening in the area of the Gulf Trough-Apalachicola Embayment (modified from Sever, 1966). 
The Ocala "Uplift," a comparatively younger structure than the Peninsular Arch (fig. 5), first began to develop southwest of the arch during post-Oligocene or lower Miocene, based on the configuration of Miocene sediment that directly overlies upper Eocene carbonates (fig. 10) and the lack of thinning of Eocene sediments along the crest of the uplift (Chen, 1965). Winston (1976) attributed the uplift to an anomalous buildup of middle Eocene carbonates. Miller
(1986) suggested that differential compaction of these sediments shortly after deposition had given rise to the Ocala "Uplift." Often confused and used synonymously with the Peninsular Arch, the Ocala "Uplift" represents a gentle and local flexure parallel to the Peninsular Arch in central Florida where middle to upper Eocene sediments outcrop on the west coast of the peninsula (Chen, 1965).

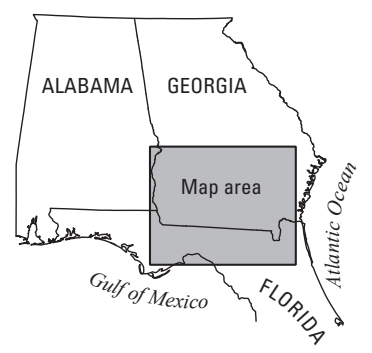

EXPLANATION

MAP

Approximate location of Gulf TroughApalachicola Embayment

Study area boundary

$A-A^{\prime}$ Line of section

- - - - Approximate boundary of Southeast Georgia Embayment
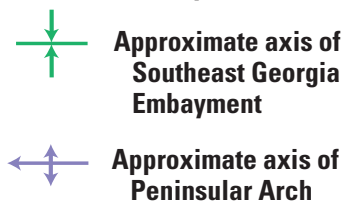
Peninsular Arch

CROSS SECTION

Hydrologic unit

Surficial aquifer system

Upper semiconfining unit Upper Floridan aquifer

Lower confining unit

Geologic contact
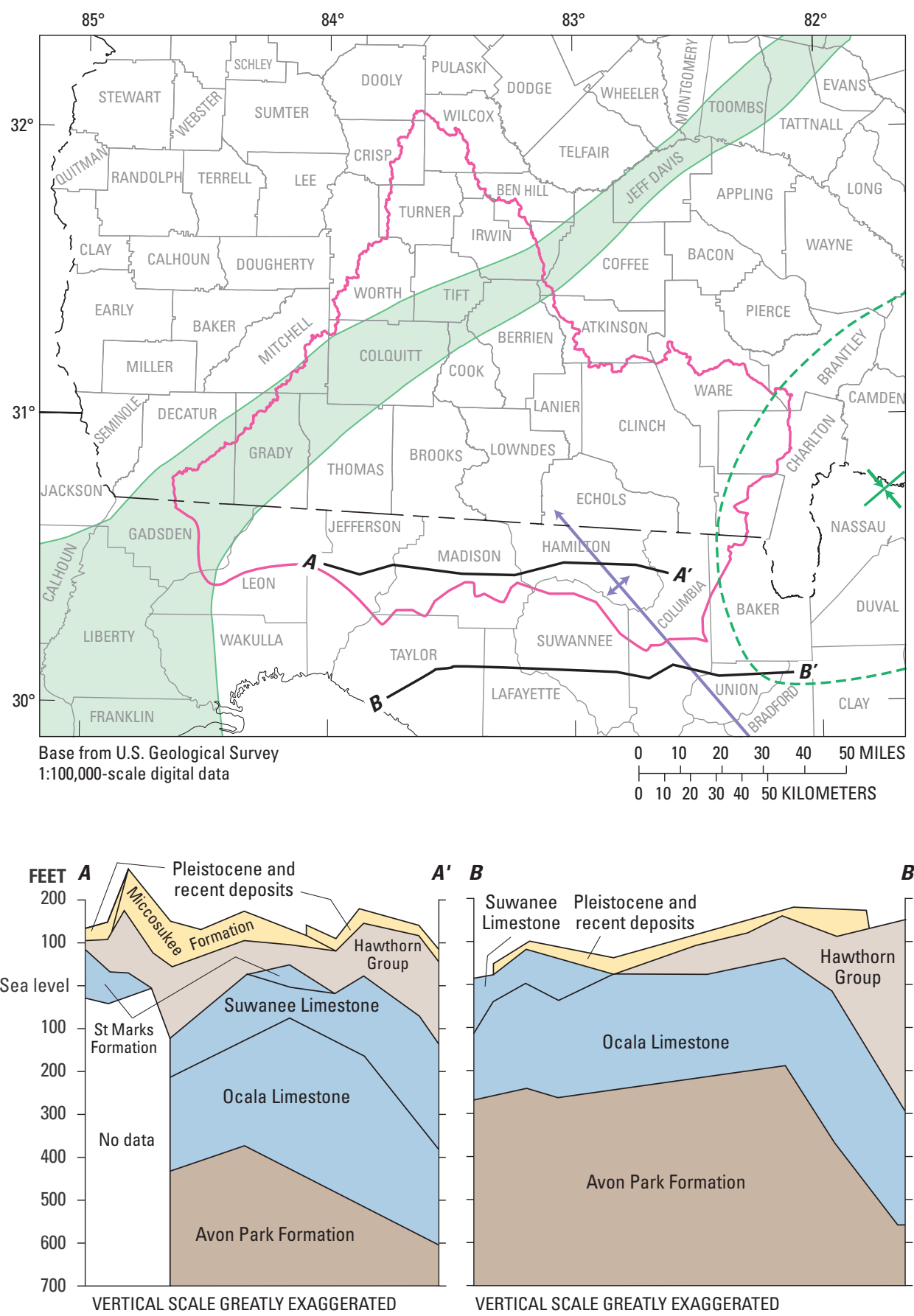

$A^{\prime} \quad B$

$B^{\prime}$

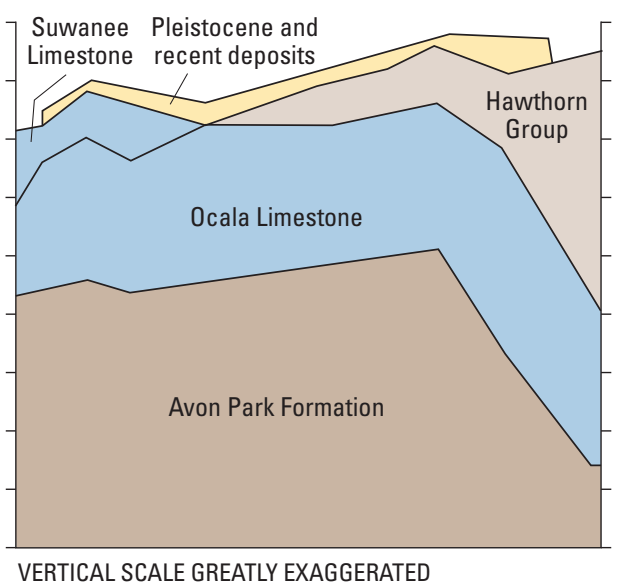

Figure 10. Geologic sections across northeastern Florida showing accumulation of Eocene sediment over the Peninsular Arch along $A-A^{\prime}$, from western Jefferson County, Florida, to Columbia County, Florida; and $B-B^{\prime}$, from Taylor County, Florida, near Gulf of Mexico, to Bradford County, Florida (modified from Kellam and Gorday, 1990; Davis, 1996a; Raulston and others, 1998). 
The Suwannee Strait (Dall and Harris, 1892) represents a negative feature, such as a closed basin or trough, within which several stratigraphic units are anomalously thin (Miller, 1986). Paleocene to Eocene environmental stress and sea-level rise possibly suppressed carbonate-sediment production, prohibiting accumulation rates from keeping pace with tectonic subsidence (Hine and others, 2001). Dall and Harris (1892) described the Suwannee Strait as a northeast-trending trough extending from the Suwannee River in Florida through the Okefenokee Swamp. Well data indicate a closed depression on the top of the Paleocene, compatible with an extension of the Southeast Georgia Embayment but separated from the embayment by a sill-like ridge (Miller, 1986). Miller (1986) suggested that during early Eocene, the Suwannee Strait ceased to be an actively subsiding basin and accordingly, had little effect on the Floridan aquifer system except that the aquifer thickens slightly within the strait. Deltaic sedimentation by rivers draining off the Appalachian Mountains during late Oligocene probably caused infilling of the seaway. This deltaic sedimentation extended southward and onlapped carbonates of northern Florida (Hine and others, 2001).

Applin and Applin (1944) suggested the existence of "a channel or trough extending southwestward across Georgia through the Tallahassee area to the Gulf of Mexico." "This channel cut nearly at right angles to the trend of the Peninsular Arch and lay between the carbonate-evaporite facies to the southeast and the terrigenous clastic facies to the north and northwest" (Chen, 1965). Jordan (1954) termed this channel the Suwannee Strait, in apparent conflict with the previous usage of the term by Dall and Harris (1892).

The Suwannee Strait possibly formed beneath the Suwannee Seaway and combined with the Gulf Trough to form consecutive seaways linking the Gulf of Mexico with the Atlantic Ocean (Hine and others, 2001). Chen (1965) attributes the continuous existence of the Suwannee Strait (or "Channel") during Paleocene and lower Eocene to current action that "considerably reduced the rate of accumulation of fine sediments ... and would have prevented the spread of fine terrigenous sediments over the peninsula area to the southeast." Applin (1951) recognized distinct clastic and non-clastic sedimentary facies in the area of the Suwannee Strait; these facies have shifted northward and northwestward through geologic time (Chen, 1965).

A number of investigators have expressed various explanations about the nomenclature associated with the structural feature known as the Gulf Trough as well as its origin. Herrick and Vorhis (1963) associated the name Gulf Trough of Georgia (or Gulf Trough, figs. 5 and 6) with the same structural feature described previously as the Suwannee Strait by Dall and Harris (1892) and Jordan (1954) (fig. 8). Sever (1966) defined the Meigs Basin as a local synclinal sedimentary structure of the larger Suwannee Strait, or Gulf Trough, in northwestern
Thomas County, Ga. (fig. 9). The principal hypotheses for the origin of the Gulf Trough have been summarized by Patterson and Herrick (1971) and listed by Zimmerman (1977). These hypotheses are that the Gulf Trough defines (1) a buried submarine valley or strait analogous to the Straits of Florida; (2) a graben; (3) a syncline; or (4) a buried solution valley analogous to the Flint River valley (fig. 11).

In the Flint River valley, solution and weathering of carbonate rocks transformed the Oligocene Suwannee Limestone into a residuum (Flint River residuum) of greatly reduced thickness (fig. 11). Weathering completely leached the Suwannee Limestone and replaced it with silica that formed chert boulders in the residuum (Vorhis, 1972). By analogy, the Marianna Limestone and Byram Formation supplanted the Lisbon Formation and Ocala Limestone in the Gulf Trough region by sedimentation, rather than through solutioning and weathering as in the Flint River valley. The resulting formation consisted of a thick, low-water-transmitting zone in the aquifer containing poor water quality.

Herrick and Vorhis (1963), Gelbaum (1978), and Gelbaum and Howell (1982) identified a series of northeasterly trending boundary faults in the Gulf Trough region. Miller (1986) described a process where low-permeability clastic sediments fill grabens in the fault zone and are juxtaposed with high-permeability limestone units in the Floridan aquifer system. Zimmerman (1977) described the pinch-out of highpermeability Upper Eocene fossiliferous limestone along the trend of the Gulf Trough and deposition of low-permeability Oligocene dolomitic limestone and marl in its place (fig. 8). The juxtaposition of low-permeability sediments of the Gulf Trough with high-permeability limestone presents a barrier to groundwater flowing southeastward in the Upper Floridan aquifer from outcrop/recharge areas located to the northwest of the study area (figs. 9 and 12).

\section{Geologic Units}

Structural control of sedimentation in the ASO River Basin resulted in a vertically layered sequence of clastic and carbonate sediments that also grades laterally within these layers to define geologic units. The sequence of middle Eocene and younger geologic units provide the setting for groundwater and surface-water exchange within the Upper Floridan aquifer, lower and upper semiconfining units, and surficial aquifer (fig. 4).

A lithostratigraphic-transition zone in south-central Gadsden County, Fla., divides late Eocene calcareous and clastic facies and separates low-permeability middle Eocene carbonates of the Avon Park Formation of northern and peninsular Florida from the age-equivalent, glauconitic, sandy, and clayey limestone and sand of the Lisbon (Rupert, 1990) and Tallahatta Formations to the west (Miller, 1986) (fig. 4). The 


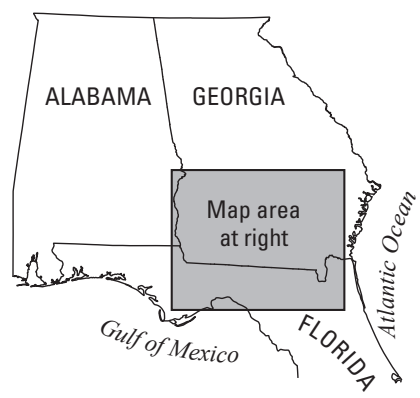

EXPLANATION

MAP

Approximate location of Gulf Trough-Apalachicola Embayment

- Study area boundary

$A-A^{\prime}$ Line of section

16P251 Well and identification number

CROSS SECTION

Hydrologic unit

Surficial aquifer system

Upper semiconfining unit Upper Floridan aquifer

Lower confining unit

Geologic contact-

Dashed where inferred
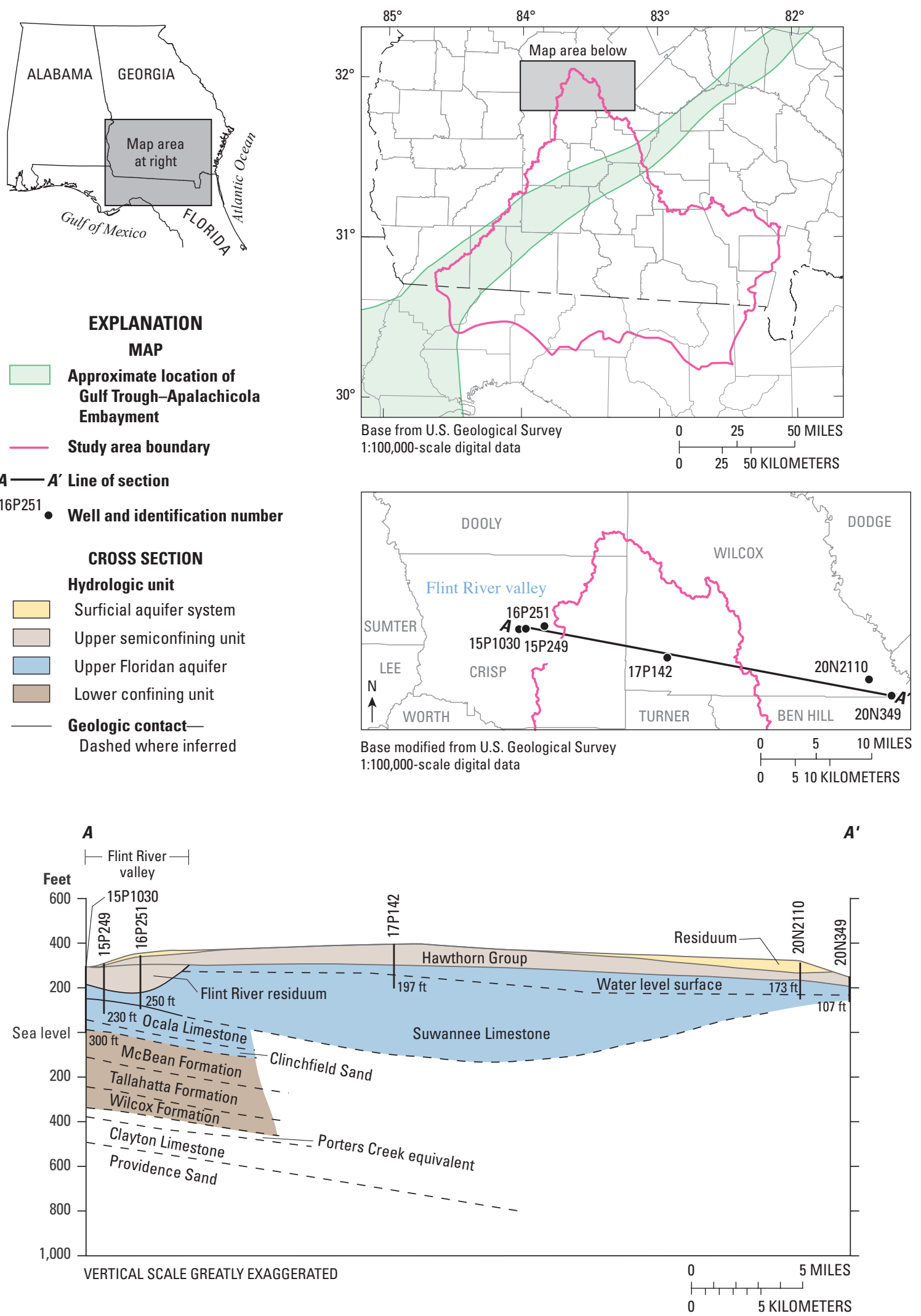

Figure 11. Geologic section across Crisp and Wilcox Counties, Georgia, showing reduction of Suwannee Limestone thickness to Flint River residuum (modified from Vorhis, 1972). 

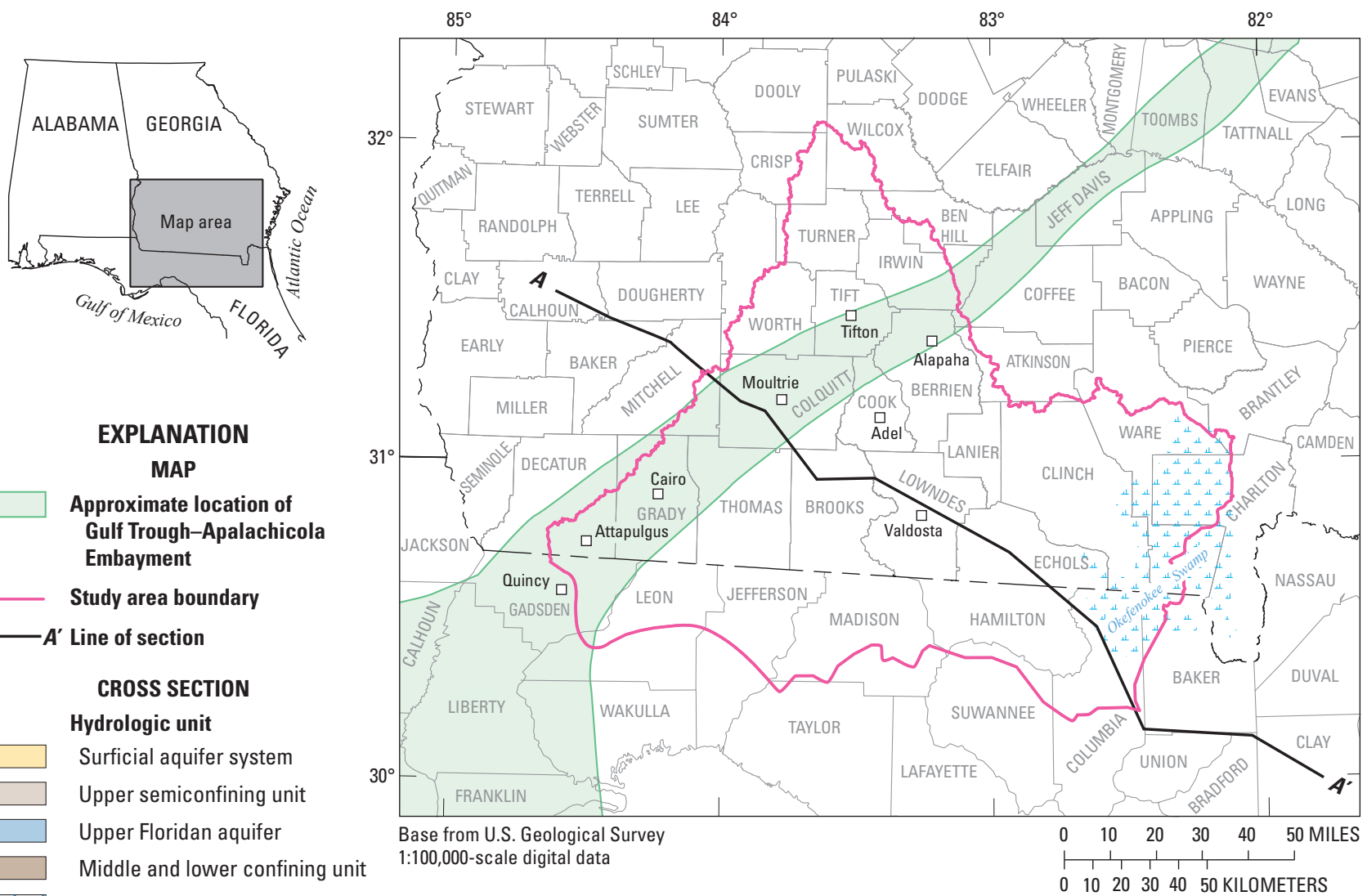

Lower Floridan aquifer

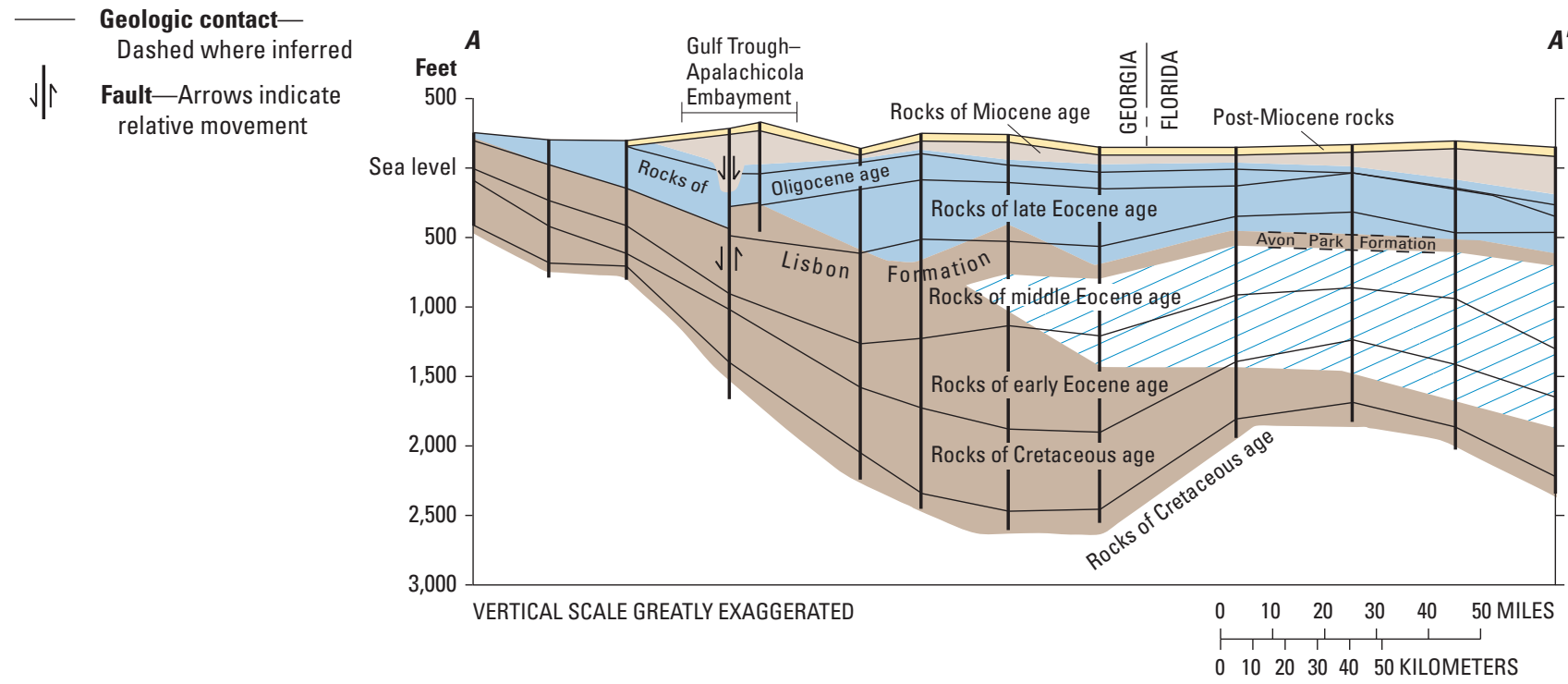

Figure 12. Geologic section of Floridan aquifer system from Calhoun County, Georgia, southeast to Clay County, Florida, showing hydrostratigraphic relations and structure of sediments in the Aucilla-Suwannee-Ochlockonee River Basin (modified from Miller, 1986). 
middle third of the Avon Park Formation in the eastern half of the Florida peninsula and in much of southeastern Georgia is micritic, finely pelletal limestone; the lower half of the Avon Park Formation in west-central peninsular Florida consists of gypsiferous limestone and dolomite. In the Florida peninsula and southeastern Georgia, the variable lithology of the Avon Park Formation constitutes a subregional confining unit within the Floridan aquifer system (Miller, 1986). The Lisbon Formation defines the lower confining unit of the Upper Floridan aquifer (Miller, 1986) in the northern, western, and north-central parts of the study area; the Avon Park Formation defines the lower confining unit of the Upper Floridan aquifer to the south and east.

The middle Eocene Lisbon and Avon Park Formations hydraulically separate water-bearing carbonates of the Floridan aquifer system into two major permeable zones termed the Upper and Lower Floridan aquifers (Miller, 1986) (fig. 12). The area of separation of these permeable units occurs in a region bounded by Moultrie, Ga., to the north, the Okefenokee Swamp and Baker County, Fla., to the east, and Attapulgus, Ga., and Quincy, Fla., to the west. Miller (1986) indicates the occurrence of a Lower Floridan aquifer near Valdosta, Ga. Here, the Lisbon and Avon Park Formations form a middle confining unit to the Upper and Lower Floridan aquifers; however, gypsiferous rocks of the intervening confining unit grade downward into low-permeability clastic sediments of the aquifer system's lower confining unit, where total confining-unit thickness exceeds $200 \mathrm{ft}$. Well data limit the definition and areal extent of these confining units because neither unit crops out in the study area. This separation sufficiently impedes groundwater and surface-water exchange with Paleocene-to-middle-Eocene rocks of the Lower Floridan aquifer in the ASO River Basin; thus, these units are not discussed in this report. Further, the middle confining unit of Miller (1986) functions as and is termed the lower confining unit of the Upper Floridan aquifer. Accordingly, only latemiddle Eocene-to-Holocene geologic units (fig. 4) define the hydrologic setting for groundwater and surface-water exchange in the basin.

The mostly carbonate middle-to-late Eocene Ocala Limestone and late Oligocene Suwannee Limestone (fig. 4) form a single, vertically continuous, permeable layer in the Upper Floridan aquifer in updip parts of the ASO River Basin toward the northwestern boundary. The Ocala Limestone consists of an upper part containing white, soft, friable porous coquina, large forams, bryozoan fragments, and echinoid remains in a micritic limestone matrix. A lower part contains cream-towhite, fine, soft to semi-indurated micritic limestone with miliolid remains and scattered forams, and glauconite locally. To the east of the Flint River in Dooly and Crisp Counties, the Suwannee Limestone weathered into the Flint River residuum (fig. 11) or Flint River Formation, "making a porous permeable unit that favors recharge" (Vorhis, 1972).
In the southwestern part of the basin near Cairo, Grady County, Ga., nearly $400 \mathrm{ft}$ of middle Oligocene sediments separate the Suwannee and Ocala Limestones. These sediments consist of the stratigraphically equivalent Marianna Limestone and Byram Formation, which were known previously to exist only in Florida. Formerly considered part of the late Eocene Ocala Limestone (Sever and Herrick, 1967), sediments of the Marianna Limestone and Byram Formation have been included in the Suwannee Limestone (Davis, 1996a). The Byram Formation consists predominantly of yellowish-brown, dense, clayey, finely crystalline dolomite and is similar to the Byram Formation described by Puri and Vernon (1964) at an outcrop in Jackson County, Fla. (Sever and Herrick, 1967). The Marianna Limestone consists of interbedded pale orange to cream, soft, granular, fossiliferous limestone, cream fossiliferous marl, and thin beds of pale-grown dolomite and dolomitic limestone. Foraminiferal evidence correlates part of the nearly $500 \mathrm{ft}$ of middle Oligocene sediments penetrated in a test well at Cairo, Ga., with the Marianna Limestone of Florida, as well as with part of a 635 -ft section of sediments from a well in Coffee County, Ga. (Sever and Herrick, 1967). The northeastward trend of these sediments from Grady to Coffee Counties coincides with the location of the Gulf Trough-Apalachicola Embayment (fig. 6), inferring continuous separation of the Suwannee and Ocala Limestones by geologic units of similar lithology as the Byram Formation and Marianna Limestone in a southwest-to-northeast corridor.

The Suwannee Limestone consists of hard to soft, yellowish-gray, calcitized, crystalline fossiliferous limestone in the western part of the study area near Cairo, Grady County, Ga. (Sever and Herrick, 1967). In southwestern Georgia, along the Solution Escarpment, and in the eastern panhandle of Florida, the Suwannee Limestone consists of cream to tan, crystalline, vuggy limestone with gastropod and pelecypod casts and molds. Another facies contains white to cream, finely pelletal limestone with small foraminifers, pellets of micrite bound by a micritic to finely crystalline limestone matrix. Fine sand in cast and mold facies is present locally. The micritic pelletal facies contains trace amounts of fine to medium, light to dark-brown phosphate (Miller, 1986). South and west of the Solution Escarpment, and in Florida, dolomitic, silty, and sandy limestone layers of early-to-middle Miocene Tampa Limestone and Chattahoochee and St. Marks Formations (fig. 4) represent permeable zones that contribute locally to aquifer thickness; although clastic sediments mostly compose Miocene and younger units (Miller, 1986). A transition zone near south-central Gadsden County, Fla., separates the calcareous downdip (southeastward) facies of the Tampa Limestone, termed the St. Marks Formation (Puri, 1953; Rupert, 1990), from the clastic updip (northwestward) facies, termed the Chattahoochee Formation (Puri and Vernon, 1964; Rupert, 1990; Scott, 1986, 1992). Stratigraphically, the Chattahoochee Formation grades upward into the siliciclastic and clayey 
middle-to-late Miocene Hawthorn Group-Torreya Formation in Florida (Rupert, 1990) and the basal part of the Hawthorn Group in Georgia (Huddlestun, 1988).

Middle-to-late Miocene deposits termed the Torreya Formation (Banks and Hunter, 1973) in the eastern panhandle of Florida, and the Hawthorn Group (Huddlestun, 1988) in Georgia and in the remaining parts of the study area in Florida (fig. 4), contain very fine-to-medium, clayey sand, silty clay, limestone, dolomite, and phosphate grains. Beyond the study area, to the west of the Apalachicola River in Florida, Hawthorn Group sediments transition to a thinly bedded, fine-to-coarse clastic, shelly sequence termed the Alum Bluff Group (Miller, 1986). In Georgia, the Alum Bluff Group was identified by previous investigators in Colquitt County (Zimmerman, 1977) (fig. 8) and Thomas County (Sever, 1966) (fig. 9); however, Sever (1965) described equivalent geologic units of the Alum Bluff Group as the "Hawthorne Formation." Hawthorn Group sediments range in thickness from a featheredge in northwestern Colquitt County to about $300 \mathrm{ft}$ in or near the Gulf Trough-Apalachicola Embayment (Zimmerman, 1977). The "Hawthorne Formation" thickens to $500 \mathrm{ft}$ in Ware County, where very sticky, cohesive, greenish-blue clay in the upper part of the formation confines sandy and phosphatic dolomite and limestone of the middle and lower parts, in addition to confining the underlying Upper Floridan aquifer (Matthews and Krause, 1984).

Carbonate sediments of the Hawthorn Group-Torreya Formation (fig. 4) consist of clayey limestone or dolomitic limestone, which grade downward to a predominantly limestone base in the western part of the study area in Gadsden County, Fla. Fossiliferous and phosphatic sand and fuller's earth (palygorskite) clay, montmorillonite, and kaolin clay interfinger with limestone and dolomite (Rupert, 1990). Dense, crystalline, dolomitic limestone, and limonitic and phosphatic clay interbedded with limestone characterize the Hawthorn Group in south-central Georgia near Adel, Ga. (Herrick, 1961). Sever (1966) divided the Hawthorn-equivalent Alum Bluff Group into three mappable zones: a sandy marl lower zone, a sandy limestone middle zone, and a fuller's earth clay upper zone that is mined commercially in the Gulf TroughApalachicola Embayment region. Clastic sediments in the "Hawthorne Formation" may contain minor surficial and intermediate aquifers; however, the clastic sediments primarily function as confining units, restricting local recharge to the Upper Floridan aquifer (Pratt and others, 1996).

The Pliocene Jackson Bluff Formation (fig. 4) crops out to the west of the study area in Gadsden County, Fla., and consists of three clayey, sandy shell beds (Schmidt, 1984; Puri and Vernon, 1964). The Jackson Bluff Formation overlies either the Tampa Limestone or the Hawthorn Group-Torreya Formation, depending on the presence of each unit, and functions as a semiconfining unit, impeding vertical movement of water into and out of deeper water-bearing units (Torak and McDowell, 1996).
The Citronelle Formation exists only in the southwestern part of the ASO River Basin and consists of late Pliocene, orange to red, clayey, medium to coarse, quartz sand containing clay lenses and beds of friable quartz pebbles. About $90 \mathrm{ft}$ of Pliocene gravel and coarse sand termed the Citronelle Formation overlies Hawthorn-equivalent sediments of the Alum Bluff Group in northwestern Thomas County (fig. 9). In the absence of Holocene and Pleistocene deposits, sediments of the Citronelle Formation exist at land surface, capping many of the hills in Gadsden County, Fla. In Decatur, Grady, and Seminole Counties, Ga., Sever (1965) described a Citronelle-equivalent, unnamed red clayey sand and gravel containing hematite concretions, and in Thomas County, Sever (1966) described the Citronelle Formation as cross-bedded, yellow to red gravel, sand, and clay. Thickness varies from about 20 to $100 \mathrm{ft}$; although the original thickness is uncertain because of removal by erosion throughout much of its areal extent. Zimmerman (1977) noted small isolated patches of the Citronelle Formation in Colquitt County, Ga. To the east, the reddish siliciclastic sediments are lithologically similar to the late Pliocene Miccosukee Formation (Rupert, 1990) (fig. 4). Clay lenses in the Citronelle Formation impede groundwater recharge from precipitation and limit vertical leakage to the underlying Hawthorn Group and Upper Floridan aquifer.

The Miccosukee Formation contains interbedded clay, silt, sand, and gravel, similar in overall lithology to the Citronelle Formation, except that the Miccosukee contains less gravel and more fine-to-medium clayey sand than the Citronelle (Rupert, 1990). Sediments of the Miccosukee Formation extend eastward from Gadsden County, Fla., and northeastward into Georgia, pinching out in the south-central part of the study area in eastern Madison County, Fla. (Rupert, 1990). The Miccosukee Formation caps topographically high areas on the Tifton Upland and lies unconformably on the Miocene Hawthorn Group-Torreya Formation. The Red Hills region of the Ochlockonee and Aucilla River Basins most likely owes its name to the distinct reddish color of siliciclastic sediments of the Miccosukee and Citronelle Formations, which contribute to the sediment load of those streams giving them a distinct yellow color. The predominantly clayey quartz sand and sandy clay identified in exposures and core of the Miccosukee Formation can impede groundwater recharge to the underlying Hawthorn Group and Upper Floridan aquifer; although locally sandy zones can yield groundwater to domestic wells.

Pleistocene and Holocene undifferentiated sand and clay mantle most of the surface of the study area forming the uppermost water-bearing zones of the surficial aquifer system (fig. 4). Marine-terrace deposits consisting of Pleistocene undifferentiated quartz sand and clay lie unconformably on the Citronelle, Miccosukee, Torreya, or Chattahoochee Formations in the western part of the study area in Florida. Holocene alluvial deposits thinly blanket stream valleys and commonly are indistinguishable from Pleistocene sediments (Rupert, 1990). 


\section{Hydrologic Setting}

Groundwater flow and exchange with surface water in the ASO River Basin occur within a hydraulically connected sequence of middle Eocene to Holocene sediments grouped according to similarities in hydraulic properties to form geohydrologic units termed the surficial aquifer system, upper semiconfining unit, Upper Floridan aquifer, and lower confining unit (fig. 4). Differences in hydraulic characteristics within and among geologic units form geohydrologic-unit boundaries that transcend time-stratigraphic and paleontological divisions. Geohydrologic units define the hydrogeologic framework for conceptualizing groundwater and surface-water exchange in the basin (fig. 13).

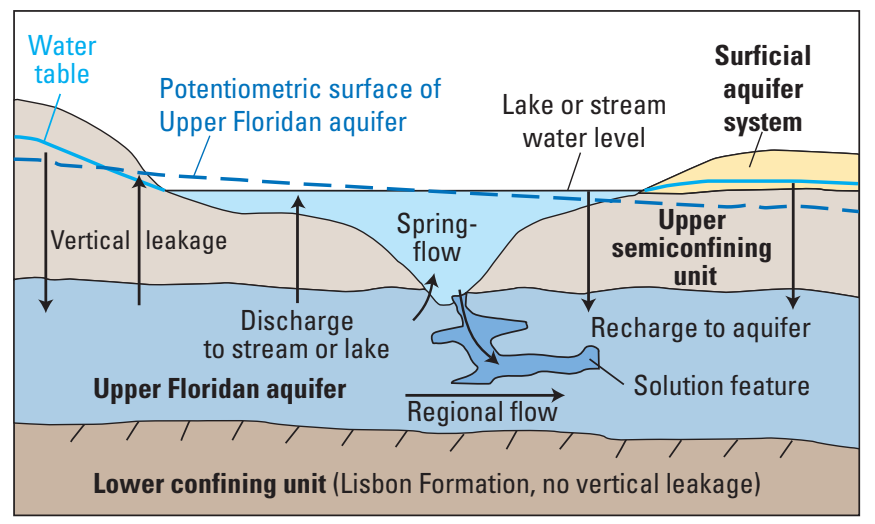

NOT TO SCALE

Figure 13. Conceptual diagram of groundwater and surfacewater flow in the interconnected stream-lake-aquifer flow system of the Aucilla-Suwannee-Ochlockonee River Basin (modified from Torak and Painter (2006).

The uppermost water-bearing zone to provide groundwater and surface-water exchange in the ASO River Basin consists of late Miocene-to-Holocene sediments termed the surficial aquifer system by the Southeastern Geological Society Ad Hoc Committee on Florida Hydrostratigraphic Unit Definition (Florida Geological Survey, 1986) and by Miller (1990) (fig. 13). The surficial aquifer system covers the study area except where erosion exposes geologic units of the upper semiconfining unit or Upper Floridan aquifer (fig. 14). Sediments of the surficial aquifer system represent "the permeable hydrogeologic unit contiguous with land surface that is comprised principally of unconsolidated to poorly indurated clastic deposits" (Florida Geological Survey, 1986), although the surficial aquifer system contains gravel, sandy limestone, limestone, clay, and silt in places (Miller, 1986). Complex interbedding of fine- and coarse-textured sediments characterizes the system (Miller, 1990).

Groundwater and surface-water exchange in the surficial aquifer system occurs where aquifer material directly contacts surface-water features, such as in stream valleys or flood plains or in the bottom of sinkhole ponds or lakes (fig. 13). The relative positions of the water table in the surficial aquifer system and the surface-water level determine the potential for recharge to the surficial aquifer system from surface-water or for groundwater discharge to surface water from the surficial aquifer system.

The surficial aquifer system interacts hydraulically with the Upper Floridan aquifer through direct contact, in the absence of the upper semiconfining unit, or indirectly by vertical leakage through a thin upper semiconfining unit (fig. 13). Miller (1986) noted the occurrence of a "surface veneer" of post-Miocene sediments, generally $10-50-\mathrm{ft}$ thick, overlying the Upper Floridan aquifer within most of the ASO River Basin. Erosion of Oligocene-to-middle-Miocene sediment associated with the Ocala Uplift near Lake City, Fla. (fig. 14), caused the surficial aquifer to contact the Upper Floridan aquifer, providing a mechanism for direct recharge of the Upper Floridan aquifer by infiltrating precipitation and vertical leakage. Erosion of Pliocene-to-Miocene geologic units and deposition of Holocene-to-Pleistocene undifferentiated sediments places the surficial aquifer system in contact with the Upper Floridan aquifer in southeastern Thomas County, Ga. (Sever, 1966). In extreme northwestern Colquitt County, Ga., erosion to a featheredge of outcropping Hawthorn Group-equivalent sediments of the Alum Bluff Group provides nearly direct contact of isolated remnants of the Pliocene Citronelle Formation with the Upper Floridan aquifer. These permeable clastic sediments function hydrologically the same as the upper part of the Alum Bluff in northwestern Colquitt County, Ga. (Zimmerman, 1977).

Indirect interaction of the surficial aquifer with the Upper Floridan aquifer occurs in Brooks, western Echols, and Lowndes Counties, Ga., where vertical leakage from overlying clastic sediment of the surficial aquifer to the underlying Upper Floridan aquifer occurs through clay confining layers (Krause, 1979). Interior drainage through deep sands of the surficial aquifer system in Columbia and Suwannee Counties, Fla., enhances recharge to the overlying Upper Floridan aquifer (Raulston and others, 1998). Less than $50 \mathrm{ft}$ of postOligocene sediment composing the surficial aquifer system and upper semiconfining unit occur in contact with the Upper Floridan aquifer along the lower half of the Withlacoochee River in Brooks and Lowndes Counties, Ga. (fig. 14). The condition of a relatively thin surficial aquifer system in direct contact with the Upper Floridan aquifer extends into Florida along the flood plains of the Alapaha, Aucilla, Suwannee, and Withlacoochee Rivers, enhancing recharge-discharge relations.

Potentially high recharge to the Upper Floridan aquifer by vertical leakage from the surficial aquifer system exists where a relatively thin (less than $50 \mathrm{ft}$ ) upper semiconfining unit separates the two aquifers (fig. 15), and where the water table in the surficial aquifer system lies above the potentiometric surface of the Upper Floridan aquifer. Subtracting estimates for the altitude of the top of the Upper Floridan aquifer (fig. 16) from the USGS National Elevation Dataset digital-elevation model of land surface (U.S. Geological Survey, 2008) yielded a distribution of the combined thickness of the surficial aquifer system and upper semiconfining unit, 


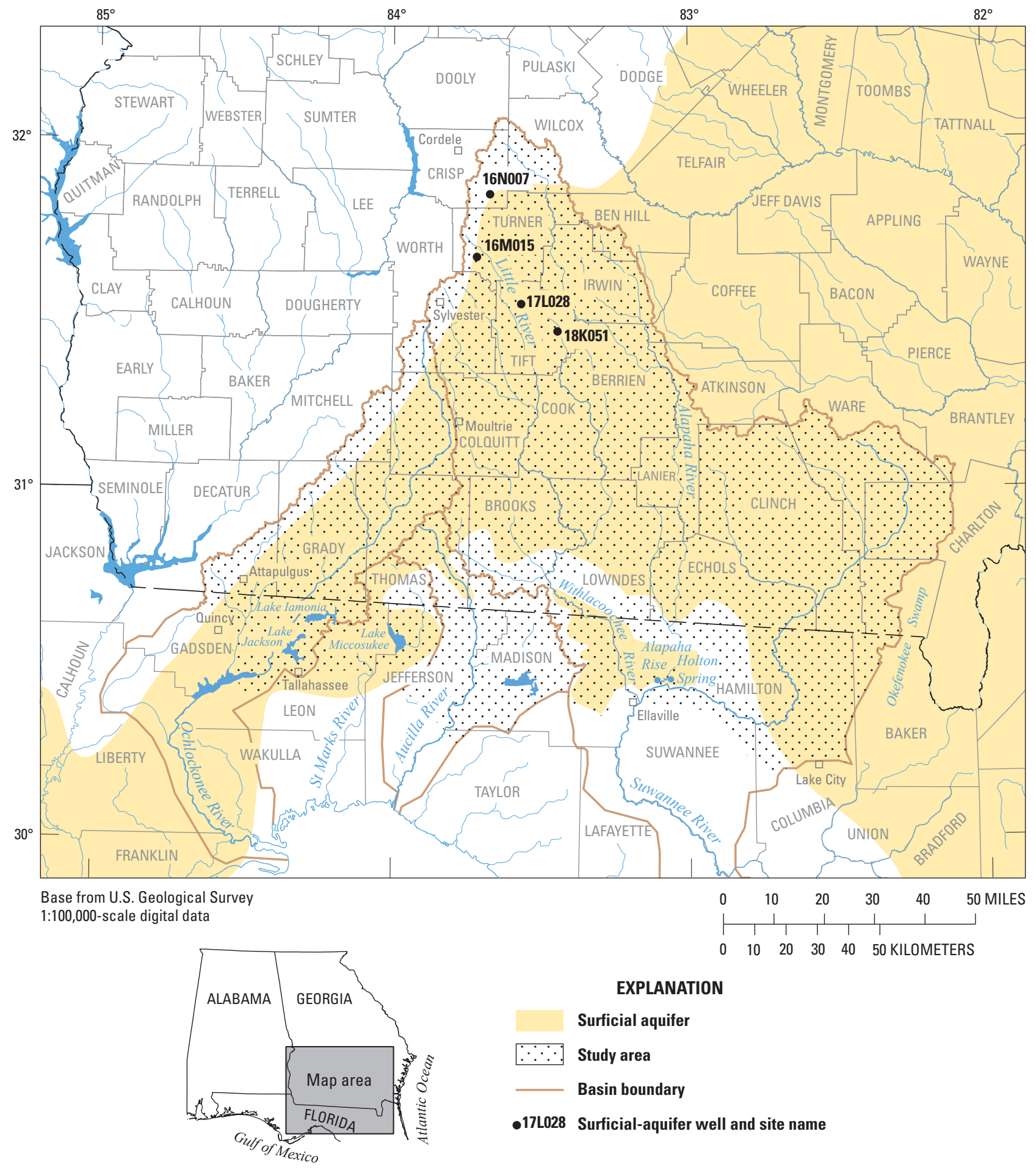

Figure 14. Areal extent of surficial aquifer system in the Aucilla-Suwannee-Ochlockonee River Basin (modified from Sever, 1966; Krause, 1979; Miller, 1990; and Raulston and others, 1998). 


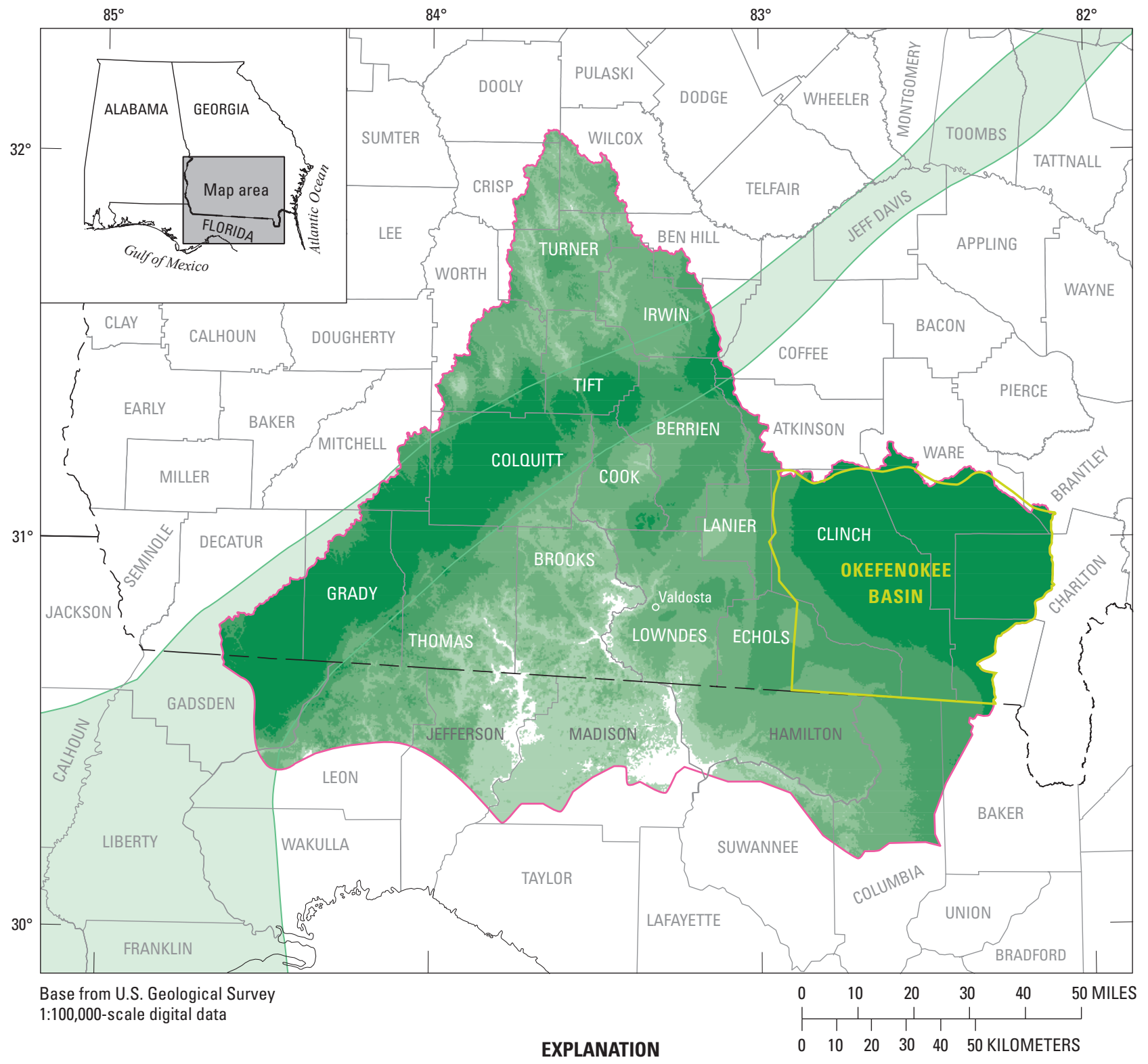

\begin{tabular}{|c|c|c|}
\hline \multirow[b]{2}{*}{$\begin{array}{l}\text { Overburden thickness } \\
\text { in feet }\end{array}$} & \multicolumn{2}{|c|}{ Potential } \\
\hline & $\begin{array}{l}\text { Vertical } \\
\text { leakage }\end{array}$ & $\begin{array}{c}\text { Water } \\
\text { exchange }\end{array}$ \\
\hline Absent & N/A & High \\
\hline Less than 50 & High & High \\
\hline 50 to 100 & Moderate & Moderate \\
\hline 100 to 200 & Low & Low \\
\hline 200 to 300 & Extremely low & Extremely low \\
\hline Greater than 300 & None & None \\
\hline
\end{tabular}

Approximate location of Gulf Trough-Apalachicola Embayment

${ }^{*}$ Contains up to 50 feet of surficial aquifer system overlying upper semiconfining unit

N/A—Not applicable; direct recharge to Upper Floridan aquifer None-No vertical leakage or water exchange

Figure 15. Overburden thickness and leakage potential of the upper semiconfining unit in the Aucilla-Suwannee-Ochlockonee River Basin. 


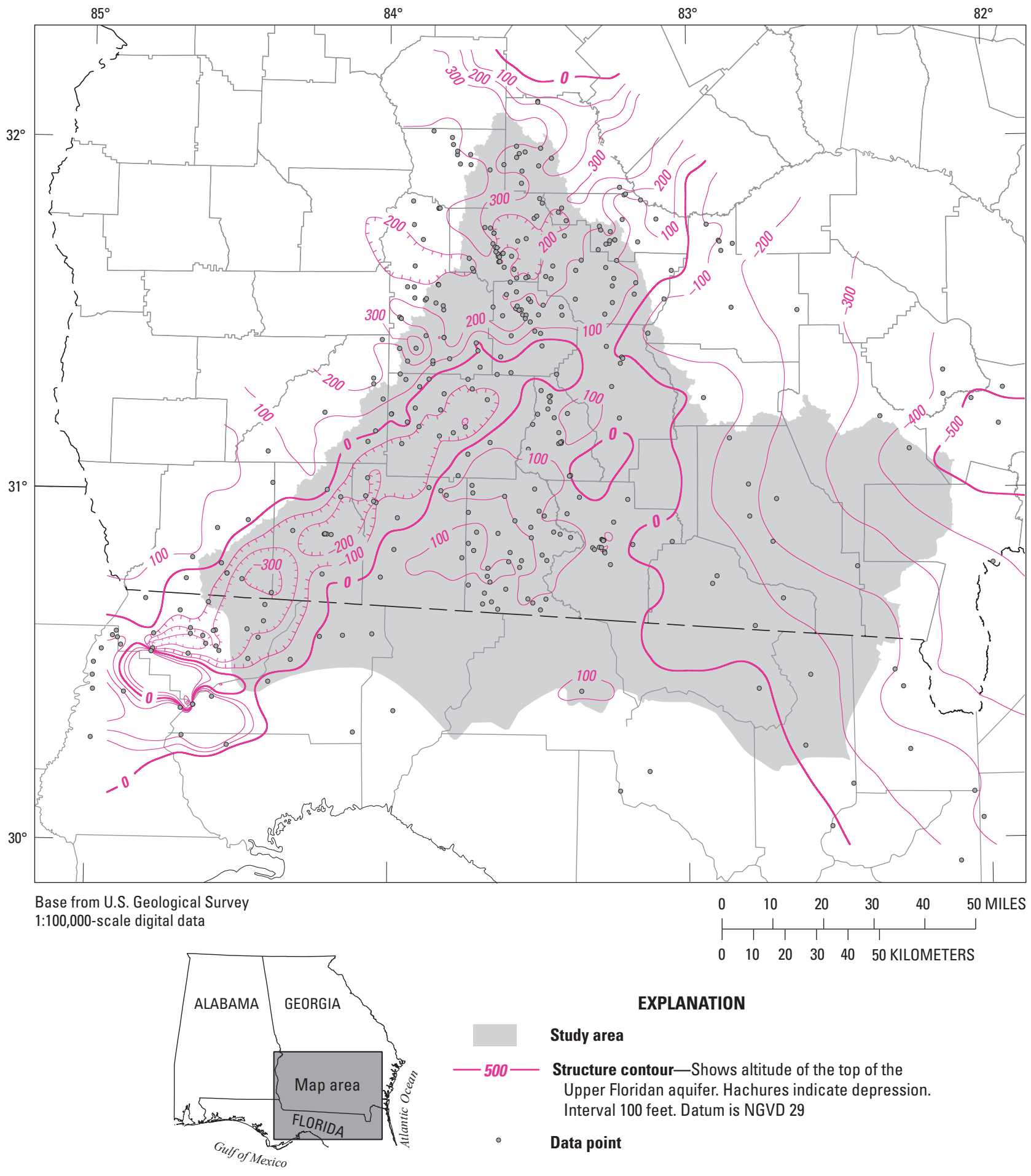

Figure 16. Altitude of the top of the Upper Floridian aquifer in the Aucilla-Suwannee-0chlockonee River Basin. 
termed "overburden." Differentiation of constituent thickness of the surficial aquifer system and upper-semiconfining-unit within the overburden was not possible from the geohydrologic data (Appendix); therefore, overburden thickness of less than $50 \mathrm{ft}$ can consist entirely of sediments constituting either the surficial aquifer system or upper semiconfining unit, as noted by Miller (1990). Overburden thickness of 50-100 ft can contain up to $50 \mathrm{ft}$ of surficial aquifer system sediments; these areas warranted classification as a moderate potential for recharge by vertical leakage. Areas of low leakage and recharge potential exist where overburden thickness of 100-200 ft occurs; extremely low leakage and recharge potential exists where overburden thickness of $200-300 \mathrm{ft}$ occurs. No potential for leakage or recharge exists where more than $300 \mathrm{ft}$ of overburden thickness occurs.

The potential exists for the surficial aquifer system to receive upward vertical leakage of groundwater from the Upper Floridan aquifer in areas where the potentiometric surface of the aquifer lies above the water table in the surficial aquifer system. In some areas, however, extensive thickness of the upper semiconfining unit and low-permeability clay and other clastic sediments limit vertical leakage between the surficial aquifer system and Upper Floridan aquifer (fig. 15).

The surficial aquifer system generally does not yield much water (Miller, 1990), although groundwater occurs under mostly unconfined conditions. The thin and discontinuous distribution of the surficial aquifer system yields sufficient amounts of water for domestic and small-farm supply from dug, jetted, or shallow drilled wells (Krause, 1979). Surficial aquifer system sediments of the Alum Bluff Group in Colquitt County, Ga., are considered unreliable because these sediments only receive recharge from precipitation (Zimmerman, 1977).

The upper semiconfining unit consists of a thick sequence of low-permeability clastic and carbonate rocks that hydraulically separate the overlying surficial aquifer system from the underlying Upper Floridan aquifer (fig. 13). Depending on hydraulic characteristics and occurrence, terrace and undifferentiated (surficial) deposits and the Citronelle, Miccosukee, and Jackson Bluff Formations constitute part of the upper semiconfining unit. Thin permeable zones in the Miccosukee Formation supply water for domestic needs in northeastern Lowndes County, Ga. (McConnell and Hacke, 1993); however, the predominantly clayey lithology and potential thickness of 100-200 ft for the Miccosukee and other Pliocene formations impede recharge of groundwater by precipitation and vertical leakage (fig. 15). The dense, clayey, dolomitic, and phosphatic lithology of the Hawthorn Group-Torreya Formation and thickness of more than $100 \mathrm{ft}$ combine with low-permeability layers in overlying geologic units to provide an effective barrier preventing recharge of groundwater to the Upper Floridan aquifer by vertical leakage from the surficial aquifer system or by infiltration of precipitation directly onto and through the upper semiconfining unit. Erosion and carbonate dissolution, however, removes this upper semiconfining unit and exposes the Upper Floridan aquifer to karstification near Valdosta, Ga., and along the
Florida-Georgia State line, promoting recharge through karst features situated at or near land surface.

Hydrologic conditions of the Upper Floridan aquifer vary from semiconfined to unconfined and hydraulic connection with surface water equally varies depending on location in the ASO River Basin. The aquifer transitions from unconfined conditions in the southern part of the study area to semiconfined conditions to the north in karst areas along the Florida-Georgia State line in Brooks and Lowndes Counties. Unconfined conditions also occur in southern Colquitt and northeastern Thomas Counties, where uplift along the flanks of the Peninsular Arch (fig. 5) and smaller structural features provided sufficient relief for late Eocene rocks and younger to be stripped away by erosion (Miller, 1986), subjecting the Suwannee and Ocala Limestones to dissolution. The Cody Scarp, located along the southern boundary of the study area (fig. 3), denotes an area of active limestone dissolution where erosion also removed overlying geologic units, exposing the Upper Floridan aquifer at or near land surface. In these karst areas, limestone dissolution increases aquifer transmissivity through the formation of solution cavities and conduit-flow conditions (fig. 13) and also increases the hydraulic connection of the aquifer with surface water.

Exposure of the Upper Floridan aquifer at land surface causes the most dynamic interaction of groundwater and surface-water exchange in the ASO River Basin. Mature karst features such as springs, steep-sided sinkholes, disappearing streams, lakes that periodically drain downward, and resurgences of disappearing streams characterize the Upper Floridan aquifer along the Cody Scarp (Raulston and others, 1998). Major rivers, such as the Withlacoochee, Alapaha, and Suwannee Rivers, flow over limestone that crops out in streambeds and freely exchange surface water and groundwater depending on the relative water levels of the aquifer and streams.

North of the Cody Scarp and karst areas in southern Georgia, thick clastic sediments of the upper semiconfining unit overlie and separate the Upper Floridan aquifer (fig. 13) from karst processes, groundwater and surface-water exchange, and recharge by infiltration of precipitation. Limited karstification in this area causes a precipitous decrease in aquifer transmissivity (Miller, 1986) and groundwater exchange with surface water. To the north of karst areas in Brooks and Lowndes Counties, upper semiconfining unit thickness in excess of $100 \mathrm{ft}$ decreases aquifer recharge by infiltration of precipitation and by vertical leakage from recharge received by direct infiltration of precipitation and surface-water leakage from streams (fig. 15).

In the northern part of the ASO River Basin, along the boundary with the ACF River Basin, recharge to the Upper Floridan aquifer occurs where the Suwannee Limestone weathered into the Flint River residuum (fig. 11). This residuum, termed the Flint River Formation by Vorhis (1972), facilitates recharge to the Upper Floridan aquifer in a limited area in Dooly and Crisp Counties along the boundary of both basins east of the Flint River (fig. 1). 
Lithostratigraphic separation of the Upper and Lower Floridan aquifers by geologic units constituting the lower confining unit, that is, the Avon Park, Lisbon, and Tallahatta Formations (figs. 4; 12), creates an effective hydraulic barrier to groundwater flow that isolates permeable zones underlying the lower confining unit from above-lying units and restricts groundwater flow (Leve, 1968). In the northern, western, and north-central parts of the study area, the Avon Park Formation contains micritic, low permeability limestone that grades into a clayey, micritic, glauconitic limestone. This lithology, in turn, grades into calcareous, glauconitic, commonly shelly sand and clay beds of the Lisbon and Tallahatta Formations (Miller, 1986). The micritic limestone and gypsiferous carbonate beds constitute important subregional confining beds within the Floridan aquifer system (Miller, 1986), and represent an impermeable base to the Upper Floridan aquifer. Near Valdosta, Ga., low-permeability rocks of the lower confining unit coalesce with deeper clastic sediments to form a confining unit of more than $200 \mathrm{ft}$ in thickness. The lower confining unit yields only small amounts of water to wells and contains high sulfide concentrations - attesting to the confining and hydraulic isolation of this unit from deep formations containing mineralized water-therefore, it functions as the lower boundary to groundwater flow and surfacewater exchange in the ASO River Basin (fig. 13).

\section{Hydrochemistry}

Limestone, dolomite, and gypsum composing the Upper Floridan aquifer supply groundwater with ions derived from dissolution of calcium carbonate, magnesium carbonate, and calcium sulfate, respectively (Torak and others, 2006). Glauconite and pyrite contained in the residuum and Upper Floridan aquifer contribute potassium, iron, silica, and sulfate ions to the chemical composition of groundwater through dissolution (Sever, 1965). Clastic Miocene and younger sediments weathered from crystalline host rocks of the Piedmont contain uranium and radioactive minerals such as monazite, a cerium-lanthanum thorium-neodymium-yttrium phosphate (Kellam and Gorday, 1990; Mineral Gallery, 2008). Groundwater derived from Miocene sediments contains the highest natural radioactivity in the Gulf Trough-Apalachicola Embayment area, specifically in Tift and Berrien Counties, Ga. (Kellam and Gorday, 1990).

The general chemical composition of groundwater in the Upper Floridan aquifer is a calcium-magnesium-bicarbonate type; however, local recharge mechanisms and lithologic variations in the geohydrologic units alter the water chemistry. Hard, calcium-magnesium-bicarbonate-type water exists near the western boundary of the ASO River Basin. In the Tifton Upland, very hard water containing sulfate occurs in some places. High iron concentration exists in a $100-\mathrm{mi}^{2}$ region that trends roughly parallel with the Solution Escarpment and Flint River, southeast of Bainbridge, Ga. (fig. 3) (Sever, 1965, fig. 2). Inferior-quality water once thought to occur in the
Ocala Limestone in Grady County, Ga., actually occurs in the overlying Byram Formation and consists of extremely hard water having high concentrations of sulfate, iron, fluoride, and dissolved solids (Sever and Herrick, 1967). Water in geologic units underlying the Upper Floridan aquifer in the western part of the study area emits a moderate hydrogen-sulfide odor because of pyrite and gypsum contained in these rocks, and probably contains high sodium and chloride concentrations as well as high concentrations of iron and sulfur (Sever, 1965).

Unstable decay of several radioactive isotopes, or daughter products, of uranium-238 cause elevated gammaray activity in the ASO River Basin that can help identify subsurface zones of high radiation emission. High-radioactive zones are represented as peaks, kicks, or points on naturalgamma geophysical logs (Wait, 1960). Laboratory results indicate that radium-226 is the dominant alpha emitter in the Gulf Trough-Apalachicola Embayment area, and that radium-228 activity is negligible (Kellam and Gorday, 1990). Radon-222 exists naturally in virtually all soil and rock as a decay product of radium-226, the fifth daughter in the decay of uranium-238 (Torak and others, 2006). As radon-222 forms, some atoms leave the soil or rock and enter the surrounding air or water (Samet and Nero, 1989).

Highly phosphatic sediment in the Hawthorn Group and phosphatic sandy Oligocene limestone and dolomite from coastal areas of Georgia are proportionately more radioactive than other local geologic units, indicating that they are a source of radon to groundwater (Torak and others, 2006). Not all wells in the Gulf Trough-Apalachicola Embayment area contain high levels of radioactivity, or gross alpha activity. Highest levels of radioactivity occur near Tifton, Tift County, and near Alapaha, Berrien County, Ga. (fig. 12). Here, municipal wells tapping Oligocene carbonates of the Upper Floridan aquifer produced higher-than-normal amounts of radioactivity. One well, City of Tifton municipal well 5, was removed from production because of high radioactivity levels. Wells containing high gross alpha activity in Tift and Berrien Counties seem to be associated with the low altitude of the top of the Upper Floridan aquifer, which contains high relief in this area (Kellam and Gorday, 1990). The structural lows in the top of the aquifer at these locations probably result from erosion or dissolution, which created a favorable environment for deposition of post-Oligocene, radioactive, phosphatic clastic sediments.

Organic material mixed with surface water enters the Upper Floridan aquifer by direct recharge in karst areas of the ASO River Basin, altering the natural water chemistry of groundwater. In the Valdosta, Ga., area, large quantities of organic material from the Withlacoochee River enter the aquifer through a sinkhole area that has been formed in the streambed, providing a source of soluble organic carbon to groundwater. About 2.6 tons of total organic carbon (TOC) was estimated to enter the Upper Floridan aquifer daily through sinkholes in the streambed from 1972 to 1989 (McConnell and Hacke, 1993). Increased concentrations of TOC, chloride, total sulfide, and methane in wells located downgradient from the sinkhole area in the Withlacoochee River, compared with 
lower concentrations in upgradient wells, indicate that mixing of organic-rich river water catalyzes the growth of microbiota in the aquifer, which in turn produces methane and hydrogen sulfide. Humic substances associated with organic material in the water can form trihalomethane during chlorination of groundwater for drinking-water supplies.

Water samples collected from the Little and Withlacoochee Rivers (fig. 1) and from wells completed in the surficial aquifer adjacent to agricultural fields in the ASO River Basin contained herbicide-degradation compounds derived from land application of the herbicides metolachlor and alachlor, indicating an active flow system consisting of groundwater and surface-water exchange (Pittman and Berndt, 2003). While streams contained mostly degradation compounds of metolachlor and alachlor, some groundwater samples contained the parent compound metolachlor; however, no groundwater samples contained alachlor. Concentrations of metolachlor in groundwater did not exceed 0.13 microgram per liter $(\mu \mathrm{g} / \mathrm{L})$, although its degradation products, metolachlor ethane sulfonic acid and metolachlor oxanilic acid, attained maximum concentrations of $19 \mu \mathrm{g} / \mathrm{L}$ and $0.13 \mu \mathrm{g} / \mathrm{L}$, respectively.

The lower confining unit yields small amounts of water containing a high sulfate concentration, which results from dissolution of gypsum (Sprinkle, 1989). Underlying units to the lower confining unit contain slow-moving, poor-quality water (Miller, 1986).

\section{Hydrologic Characteristics}

Variations in physical properties of geologic units composing the surficial aquifer system, upper semiconfining unit, Upper Floridan aquifer, and lower confining unit determine the degree of hydraulic connection among these units and control groundwater and surface-water exchange in the ASO River Basin. Areal and vertical distribution of physical properties within geohydrologic units define heterogeneities in hydrologic characteristics that improve current understanding of the relative contribution of each unit to groundwater and surface-water exchange and that refine the hydrogeologic framework and conceptual model of groundwater flow and water exchange in the basin.

\section{Surficial Aquifer System}

Hydraulic properties and groundwater level control the exchange of groundwater in the surficial aquifer system with surface water and determine the potential for vertical leakage to and from the Upper Floridan aquifer (fig. 13). Variations in thickness and areal extent determine the resource potential of the surficial aquifer system (figs. 14 and 15)

\section{Hydraulic Properties}

The surficial aquifer system blankets most of the ASO River Basin with a thin veneer of late Miocene-to-Holocene sediments typically less than 50-ft thick (Miller, 1990) (fig. 15).
Thickness of the surficial aquifer system in the southwestern part of the study area in Florida generally ranges from 30 to $50 \mathrm{ft}$ (Moore, 1955; Scott, 1992). In southeastern Georgia, thickness of about $60 \mathrm{ft}$ has been mapped (Miller, 1990).

Transmissivity of the surficial aquifer system in the study area ranges from 1,000 to 10,000 feet squared per day $\left(\mathrm{ft}^{2} / \mathrm{d}\right)$ (Miller, 1990). Miller (1990) attributed large transmissivity values to beds of shell and limestone that constitute the surficial aquifer system in eastern and southern peninsular Florida beyond the study area.

Wells completed in the surficial aquifer system generally yield less than 50 gallons per minute (gal $/ \mathrm{min}$ ) in the study area (Miller, 1990). The surficial aquifer system in the Florida part of the study area yields only small amounts of water when pumped and generally is not used (Davis, 1996a). The surficial aquifer system in Colquitt County, Ga., generally extends less than $50 \mathrm{ft}$ below land surface and supplies small amounts of water for domestic and stock use (Zimmerman, 1977). In Thomas County, Ga., one well drilled in a Miocene phosphatic sandy limestone constituting the surficial aquifer system yielded a maximum of $6 \mathrm{gal} / \mathrm{min}$ of moderately hard, good-quality water. Dug wells in Miocene sand beds produced corrosive water containing excessive dissolved iron (Sever, 1966). Holocene flood plain deposits up to 40-ft thick contain water-sorted sand and gravel that could supply domestic or light industrial needs; however, swampy conditions and the potential for flooding render these deposits untested as a water resource (Zimmerman, 1977).

Hawthorn-equivalent sediment constituting the surficial aquifer system in Cook County contains as much as $85 \mathrm{ft}$ of medium to very coarse phosphatic sand. Wells installed in this sediment produce moderate amounts of corrosive water that contain excessive dissolved iron suitable for domestic, irrigation, and industrial uses (Sever, 1972). Dug and bored wells completed in Pleistocene-to-Holocene alluvial deposits provide moderate amounts of water from quartz sand and gravel up to $30-\mathrm{ft}$ thick.

\section{Groundwater Levels and Fluctuations}

Groundwater levels measured synchronously with stream-stage altitudes during September 2006 agree favorably and depict a potentiometric surface having a strong surfacewater influence as well as topographic control (fig. 17). The similarities in groundwater levels and stream stages indicate hydraulic connection and water exchange between the surficial aquifer system and surface water. The water table in the surficial aquifer system parallels topography in a subdued manner and generally lies within $10 \mathrm{ft}$ of land surface (Planert, 2007). Steep gradients occur between streams and ridges or hills; gentle gradients exist in broad, flat interstream areas and under broad topographic highs. Groundwater that enters the system as precipitation moves quickly along short flowpaths perpendicular to potentiometric contours and discharges to streams as baseflow (Miller, 1990). Hydraulic gradients and groundwater-flow directions change within short distances in the surficial aquifer system. 


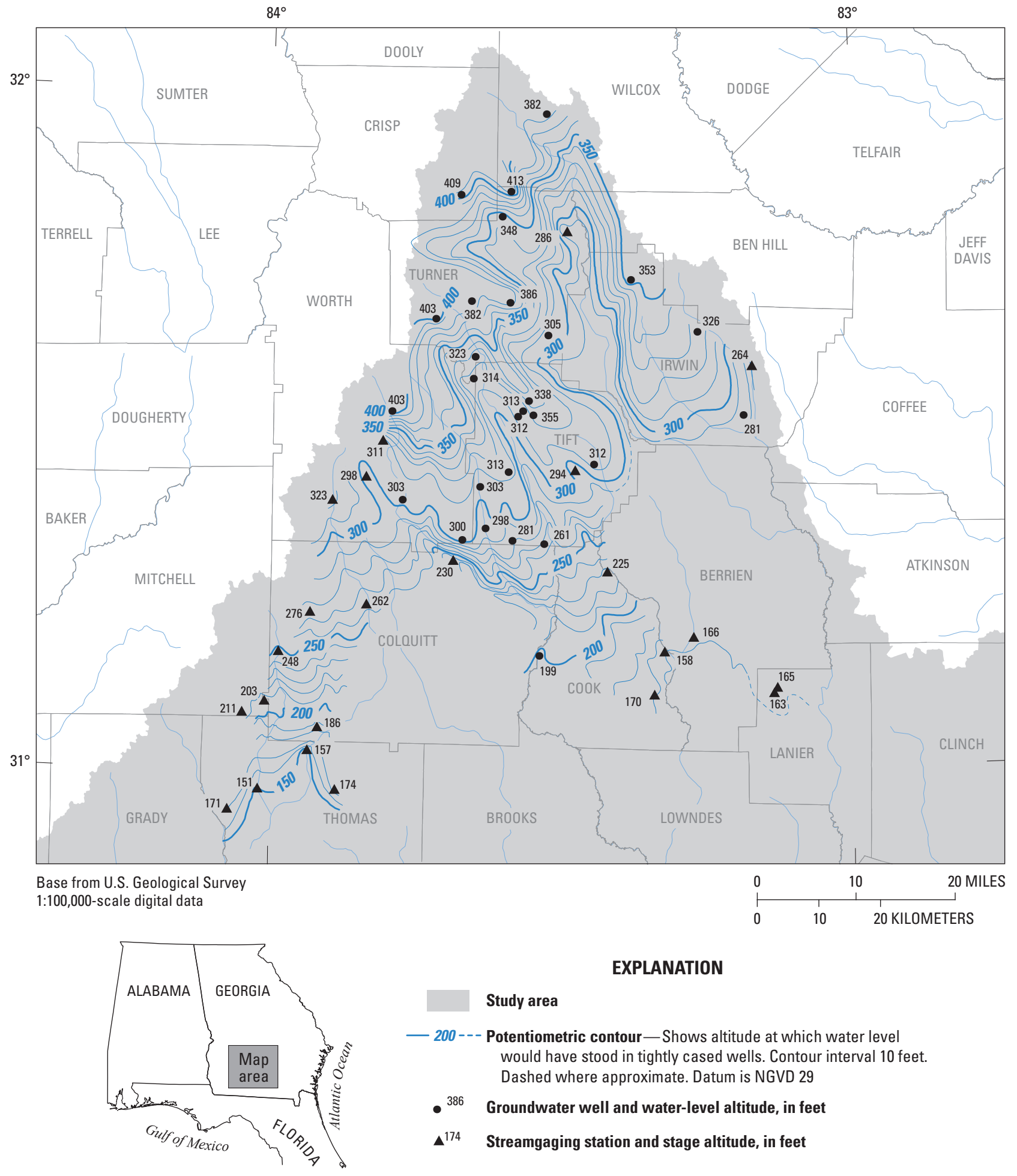

Figure 17. Potentiometric surface of the surficial aquifer system in the Aucilla-Suwannee-0chlockonee River Basin, September 2006. 
Periodic groundwater-level measurements in four wells indicate that the water table in the surficial aquifer system responds seasonally to precipitation and changes in evapotranspiration rates (fig. 18). High groundwater levels occur during late fall through early spring, when frequent precipitation from long-duration, low-intensity storms associated with frontal passages promotes infiltration. Sparse vegetation from minimal crop activity and leaf fall gives rise to low evapotranspiration rates during this time, allowing groundwater levels to recover (recharge) from the spring and summer growing season. During mid-spring through mid-fall, high evapotranspiration rates from crop vegetation and trees combine with high runoff and low infiltration of precipitation to cause seasonal groundwaterlevel decline. The limited number of water-level measurements at the four wells demonstrated the severity of dry climatic conditions during 2006 and 2007 by recording unprecedented low groundwater levels in the surficial aquifer system.

\section{Upper Semiconfining Unit}

The thickness of low-permeability clay and clastic sediments constituting the upper semiconfining unit creates a hydraulic barrier to groundwater that limits recharge to the Upper Floridan aquifer by downward vertical leakage from the surficial aquifer system (fig. 15). A low vertical-leakage potential exists where thick sequences (100-200 ft) of sediment in the upper semiconfining unit overlie the Upper Floridan aquifer.

\section{Thickness}

Thickness of the upper semiconfining unit ranges from absent in karst areas along the Florida-Georgia State line to more than $300 \mathrm{ft}$ in the Gulf Trough-Apalachicola Embayment region to the northwest and in the Okefenokee Basin to the east (fig. 15).

Davis (1996a) indicated that several hundred feet of fine-grained, low-permeability material of the upper semiconfining unit exists in the Apalachicola Embayment-Gulf Trough region of the ASO River Basin (fig. 6). Thickness of the Hawthorn Group-Torreya Formation of the upper semiconfining unit ranges from about 100 to $230 \mathrm{ft}$ in the northern and western parts of the study area (Sever, 1966; Zimmerman, 1977; and Rupert, 1990). Additional thickness of up to $100 \mathrm{ft}$ of low-permeability sediment from the Citronelle, Miccosukee, and Jackson Bluff Formations creates a substantial barrier to groundwater recharge from infiltration or vertical leakage from the surficial aquifer system. Erosion and carbonate dissolution, however, remove this upper semiconfining unit and expose the Upper Floridan aquifer at some locations in the study area, such as in southeastern Colquitt and Thomas Counties, Ga. (figs. 8 and 9, respectively), along the Withlacoochee River near Valdosta, Ga., and in karst areas along the Florida-Georgia State line.
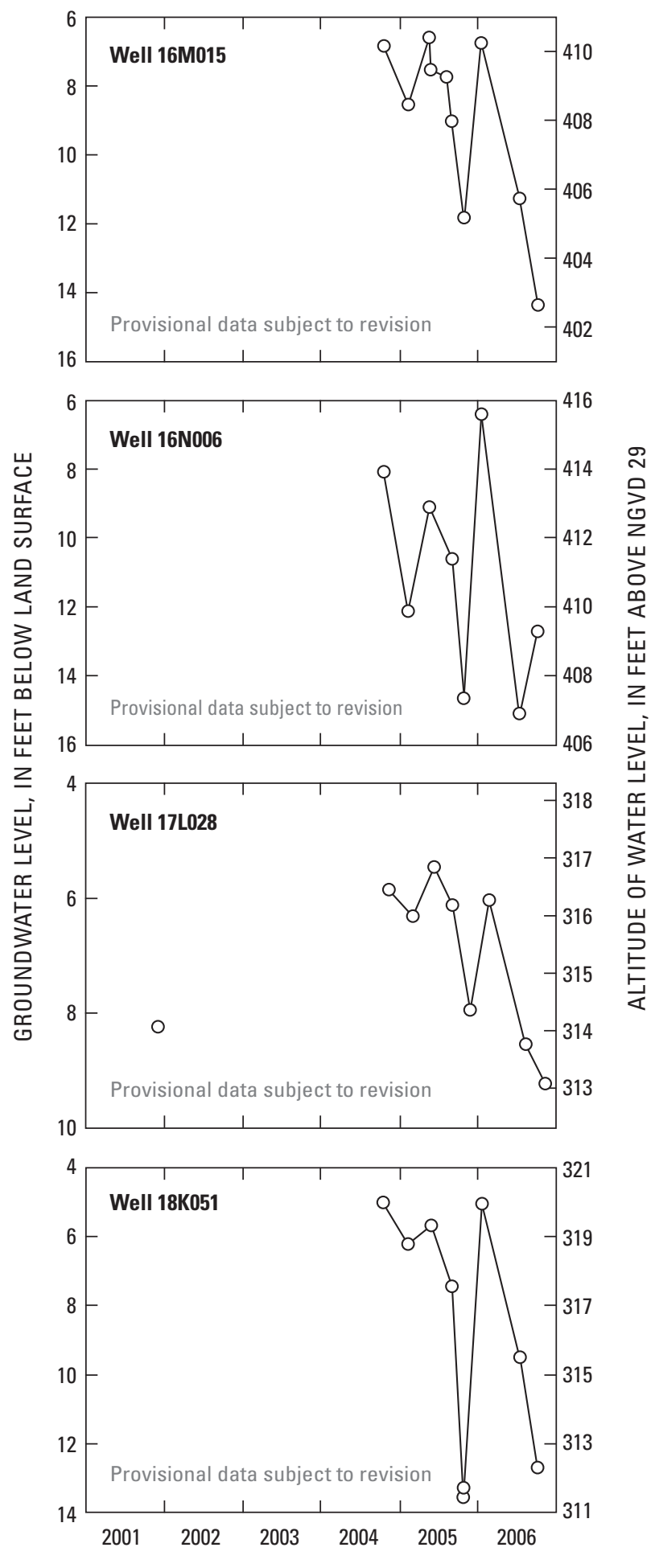

Figure 18. Groundwater hydrographs of wells 16M015, 16N006, 17L028, and 18K051, completed in the surficial aquifer system, for the period 2001-2007. 


\section{Vertical-Leakage Potential}

Thickness variations cause the upper semiconfining unit to range in hydrologic function from an impermeable boundary to allowing vertical leakage between the Upper Floridan aquifer and the surficial aquifer system or surface water (fig. 15). The upper semiconfining unit contains a high vertical-leakage potential where it is relatively thin and generally less than 50-ft thick, allowing recharge to the Upper Floridan aquifer by infiltrating precipitation or by groundwater flow from the surficial aquifer system. Areas of relatively thin upper semiconfining unit promote groundwater exchange between the Upper Floridan aquifer and surface water, such as in some upland stream valleys of the ASO River Basin north of Tifton, Ga., and northwest of the Gulf Trough-Apalachicola Embayment.

High to moderate leakage potential exists between the Gulf Trough-Apalachicola Embayment region and the State line in areas where the combined thickness of surficial aquifer and upper semiconfining unit total 50 to $100 \mathrm{ft}$ (fig. 15). These areas can contain up to $50 \mathrm{ft}$ of surficial aquifer, increasing the potential for vertical leakage from moderate to high in the absence of the upper semiconfining unit.

Moderate to low vertical-leakage potential exists in areas located between the Gulf Trough-Apalachicola Embayment and karst areas along the Florida-Georgia State line (fig. 15). In these areas, thick (more than $50 \mathrm{ft}$ ) upper-semiconfiningunit sediments overlie the Upper Floridan aquifer, limiting or preventing groundwater exchange with surface water or recharge from the surficial aquifer system.

Moderate, to low, to extremely low potential for vertical leakage and groundwater and surface-water exchange exists in a broad region of the ASO River Basin trending northeast to southwest, beginning along the western and northwestern basin boundary and extending northeast to Atkinson, Coffee, and Irwin Counties, Ga. (fig. 15). A band of increased thickness of low-permeability clastic sediments identifies the Gulf Trough-Apalachicola Embayment in this area. Little or no potential for vertical leakage and groundwater and surfacewater exchange exists in the center of this area where thickness of the upper semiconfining unit reaches $250 \mathrm{ft}$ or more.

Extremely low to no potential for vertical leakage and groundwater and surface-water exchange exists in the eastern part of the study area defined by the Okefenokee Basin (fig. 3). More than $300 \mathrm{ft}$ of low-permeability clastic sediments overlie the Upper Floridan aquifer in parts of Charlton, Clinch, and Ware Counties, Ga. (fig. 15) and effectively isolate the aquifer from groundwater and surface-water exchange and infiltration of precipitation.

\section{Upper Floridan Aquifer}

The Upper Floridan aquifer contains Eocene-to-Miocene carbonate sediments consisting of the Tampa, Suwannee, Marianna, and Ocala Limestones and the Chattahoochee, St. Marks, and Byram Formations (figs. 4, 7-12). Natural and human-induced factors affect the hydrologic characteristics of the Upper Floridan aquifer. Aquifer thickness, hydraulic properties, limestone dissolution, connection with surface water, climatic effects, and groundwater withdrawal simultaneously affect the water resources of the Upper Floridan aquifer and influence groundwater flow and exchange with surface water.

\section{Thickness Variations}

Thickness variations for the Upper Floridan aquifer (fig. 19) correspond with geologic structural control of sediment accumulation in the basin. Subtraction of the areal distribution of the base of the Upper Floridan aquifer (fig. 20) from the altitude of the aquifer top (fig. 16) yielded the thickness distribution of the Upper Floridan aquifer in the study area. The aquifer thins at the updip limits in the northwestern part of the basin, just east of the Solution Escarpment (fig. 3), and thickens substantially into the Gulf Trough-Apalachicola Embayment region (fig. 6) and seaward to the Gulf of Mexico and Atlantic Ocean, corresponding with the regional dip of geologic units. Thickness of the Upper Floridan aquifer ranges from about $150 \mathrm{ft}$ in Worth County, Ga., to more than $900 \mathrm{ft}$ in parts of Atkinson, Clinch, Grady, and Lanier Counties, Ga., and Gadsden, Hamilton, and Leon Counties, Fla. Clastic and carbonate sediments accumulated in the Gulf TroughApalachicola Embayment in Grady and Leon Counties, setting the altitude of the base of the Upper Floridan aquifer at nearly $-1,000 \mathrm{ft}$ (fig. 20). Similar sedimentation in the Suwannee Strait (fig. 5) in Clinch County, set the altitude of the base of the Upper Floridan aquifer slightly deeper than $-1,100 \mathrm{ft}$. Accumulation of sediment in the Apalachicola Embayment extends southward through Jefferson and Leon Counties, Fla., and beyond the study area in Wakulla County, Fla., where thickness of the undifferentiated Floridan aquifer system reaches about 2,800 ft (Pratt and others, 1996). Thickness of the Upper Floridan aquifer varies by about $300 \mathrm{ft}$ locally in Leon County, Fla., owing to limestone dissolution and channel erosion of the Suwannee Limestone and St. Marks Formation (Hendry and Sproul, 1966). Regional seaward thickening of Coastal Plain sediments (Miller, 1986) increases the thickness of the Upper Floridan aquifer from near zero in the northwest to more than $750 \mathrm{ft}$ in the southeast in Hamilton and Columbia Counties, Fla. 


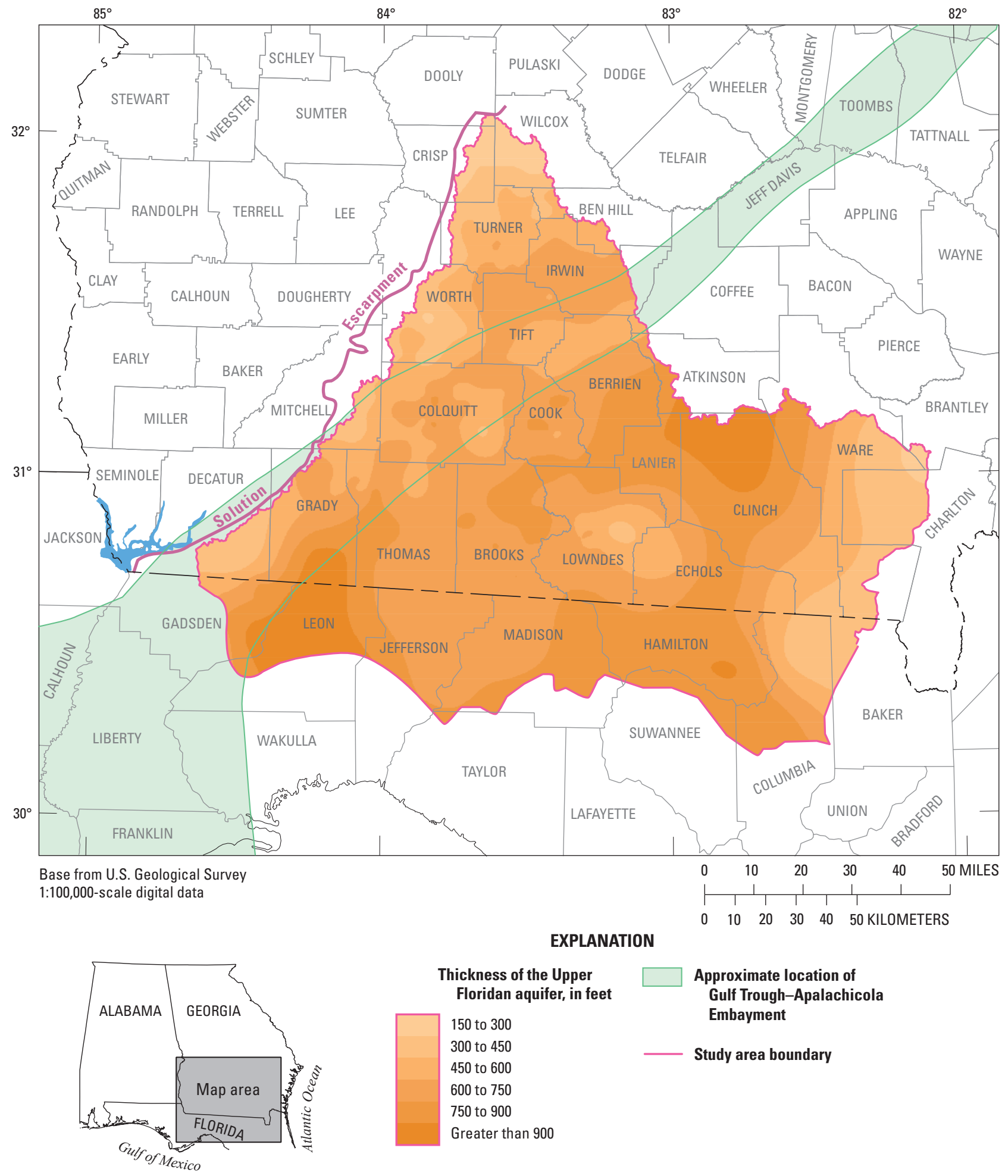

Figure 19. Thickness of the Upper Floridan aquifer in the Aucilla-Suwannee-0chlockonee River Basin. 

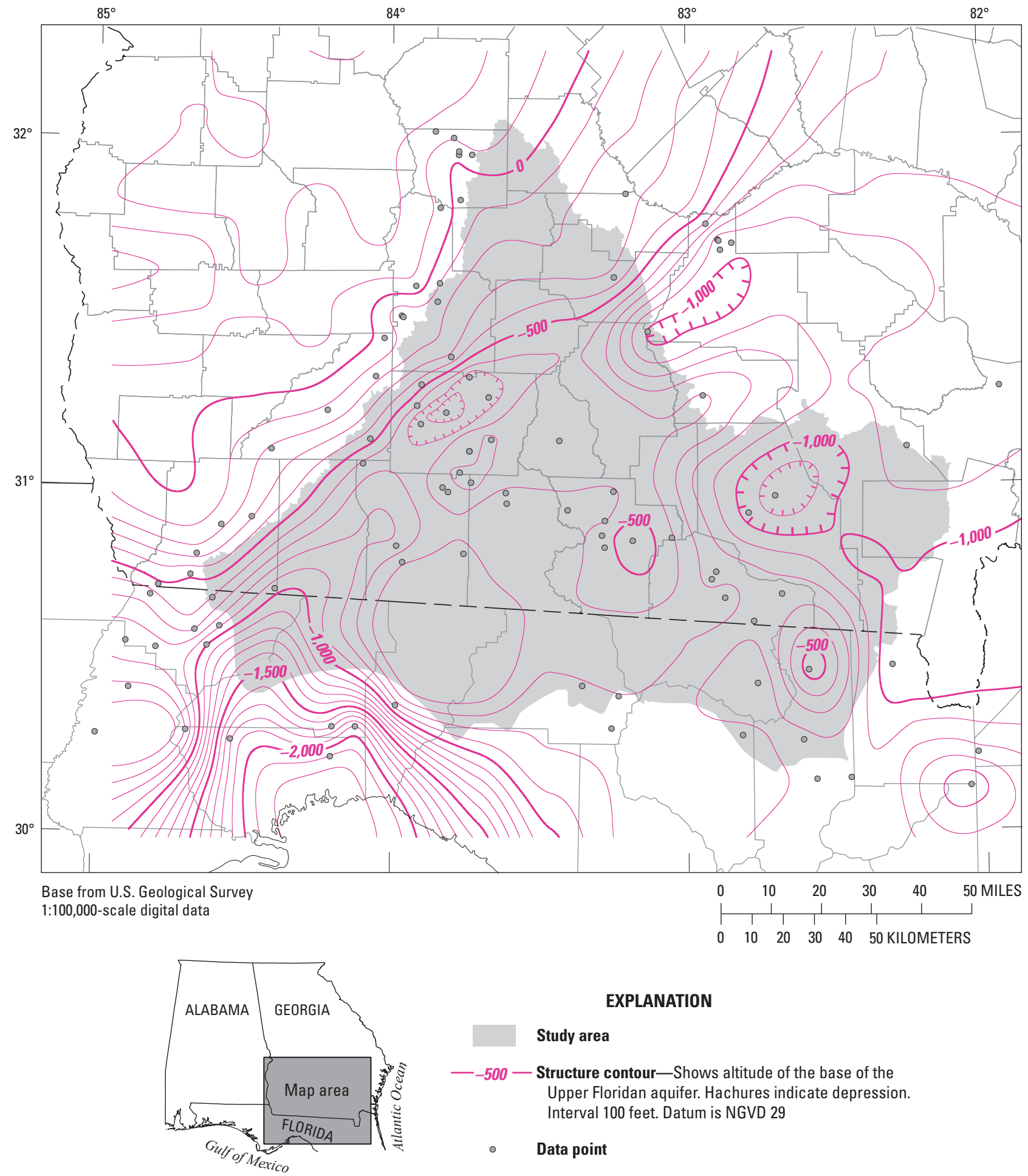

EXPLANATION

Study area

- -500 - Structure contour-Shows altitude of the base of the Upper Floridan aquifer. Hachures indicate depression. Interval 100 feet. Datum is NGVD 29

Data point

Figure 20. Altitude of the base of the Upper Floridan aquifer in the Aucilla-Suwannee-0chlockonee River Basin. 
Hydraulic Properties and the Effects of Limestone Dissolution and the Gulf Trough-Apalachicola Embayment on Groundwater Flow

Karst areas located along the Florida-Georgia State line and near Valdosta, Ga. (fig. 1) contain dissolution-enhanced hydraulic properties that facilitate groundwater flow and exchange with surface water. Limestone dissolution by water percolating through carbonate sediments enlarges subsurface pathways for groundwater flow, increasing hydraulic properties of aquifer transmissivity, hydraulic conductivity, storage coefficient, and specific yield in the Upper Floridan aquifer. Interconnected systems of solution channels and conduits, cavities, and enlarged pore space, joints, and fractures form the principal mechanisms for transmitting and storing large quantities of groundwater in the Upper Floridan aquifer in karst areas. Groundwater readily mixes and exchanges with surface water in karst areas where solution features increase the hydraulic connection of the Upper Floridan aquifer with streams and lakes. Ongoing limestone dissolution alters the landscape and reconfigures subsurface pathways, re-forming and re-orienting preferential directions of groundwater flow and enhancing groundwater and surface-water connection.

In contrast to dissolution-enhanced hydraulic properties that exist in karst areas, geologic structure and thick accumulation of clastic sediment and dense carbonate layers affect the hydraulic properties of the Upper Floridan aquifer in the Gulf Trough-Apalachicola Embayment region (fig. 6). The low water-transmitting and storage values for the Upper Floridan aquifer in the Gulf Trough region represent a limestone matrix nearly devoid of dissolution features and other groundwater-flow and storage enhancement. Joints or faults cut all or part of the Upper Floridan aquifer, juxtaposing low permeability sediment with the Upper Floridan aquifer (figs. 7-9), effectively decreasing the permeability of the aquifer and disrupting groundwater flow (Miller, 1986). The absence of secondary water-transmitting and storage features in the limestone creates an area of slow-moving groundwater, low storage capacity, and low well yield.

\section{Transmissivity and Hydraulic Conductivity}

Transmissivity of the Upper Floridan aquifer varies throughout the ASO River Basin according to changes in thickness and hydraulic conductivity because transmissivity is computed as the product of hydraulic conductivity and aquifer thickness. Generally, transmissivity increases with increased aquifer thickness (fig. 19) and (or) increased hydraulic conductivity. Geologic structure, depositional environment, and limestone dissolution affect the distribution of aquifer thickness and hydraulic conductivity within geohydrologic units constituting the Upper Floridan aquifer.

Hydraulic conductivity of the Upper Floridan aquifer increases northwestward and southeastward off the flanks of the Gulf Trough-Apalachicola Embayment, as the thick accumulation of low-permeability clastic, carbonate, and clayey sediments overlying the aquifer in the troughembayment region diminishes. Up to $500 \mathrm{ft}$ of low watertransmitting carbonates of the Byram Formation and Marianna Limestone supplant the high water-transmitting Suwannee and Ocala Limestones in the trough-embayment region (fig. 8). Northwest of the Gulf Trough-Apalachicola Embayment, hydraulic conductivity ranges from about 26-120 feet per day ( $\mathrm{ft} / \mathrm{d}$ ) in Ben Hill County, Ga., to about $220-450 \mathrm{ft} / \mathrm{d}$ in Tift County, Ga., to an exceptional regional high value of about 5,700 ft/d in Decatur County, Ga. (Kellam and Gorday, 1990) (fig. 21A). In the trough-embayment region, Kellam and Gorday (1990) indicate typical hydraulic conductivity values in the range of about $0.7-140 \mathrm{ft} / \mathrm{d}$. Two exceptions produced atypical values of hydraulic conductivity in the troughembayment region: south of Moultrie, Colquitt County, Ga. (about $770 \mathrm{ft} / \mathrm{d}$ ); and east of Cairo, Grady County, Ga. (about $5,800 \mathrm{ft} / \mathrm{d}$ ), where wells tap highly productive zones in the Upper Floridan aquifer.

Limestone dissolution increases the water-bearing capacity of the Upper Floridan aquifer in karst areas along the Florida-Georgia State line where limestone exists at or near land surface. The aforementioned 5,700-ft/d estimate of hydraulic conductivity in Decatur County (fig. 21A) demonstrates the high water-yielding potential of the Upper Floridan aquifer caused by limestone dissolution. A 6-ft vertical zone of cavities and other solution features located within $130 \mathrm{ft}$ of land surface produced nearly 90 percent of the groundwater pumped from the well associated with this large value of hydraulic conductivity, although aquifer thickness at this location totals about $350 \mathrm{ft}$ (Torak and Painter, 2006). Transmissivity understandably attained a high value of $1,300,000 \mathrm{ft}^{2} / \mathrm{d}$ as a result of this hydraulic conductivity value (fig. $21 B$ ).

Aquifer transmissivity varies widely in the ASO River Basin, more in response to limestone dissolution than to changes in aquifer thickness. Transmissivity values in the range 100,000-200,000 ft'/d (McConnell and Hacke, 1993) exist in karst areas of Valdosta, Ga. (fig. 21B), although less than $300 \mathrm{ft}$ of aquifer thickness exists in this area (fig. 19). By comparison, aquifer thickness of 500 to $900 \mathrm{ft}$ in the Gulf Trough-Apalachicola Embayment region produces aquifer transmissivity values that range from about $5 \mathrm{ft}^{2} / \mathrm{d}$ in Gadsden County, Fla. (Bush and Johnston, 1988), to $160 \mathrm{ft}^{2} / \mathrm{d}$ 
in Tift County, Ga., to $390 \mathrm{ft}^{2} / \mathrm{d}$ in Grady County, Ga., and to about 3,000 $\mathrm{ft}^{2} / \mathrm{d}$ in Colquitt and Thomas Counties, Ga. (Kellam and Gorday, 1990). On the northwestern flank of the trough-embayment region and within $10 \mathrm{mi}$ north and west of the $160-\mathrm{ft}^{2} / \mathrm{d}$ transmissivity value in Tift County, Kellam and Gorday (1990) reported transmissivity values in the range 1,200-180,000 ft $2 /$ d. Bush and Johnston (1988) reported a value of 1,300 $\mathrm{ft}^{2} / \mathrm{d}$ in Leon County, Fla., just east of the Gulf Trough-Apalachicola Embayment.

Limestone dissolution enhances hydraulic conductivity and disrupts any regional trend in transmissivity defined solely by changes in aquifer thickness. Kellam and Gorday (1990) indicate the occurrence of a large void in aquifer material penetrated by a well in Grady County that yielded a hydraulic-conductivity value of about $5,800 \mathrm{ft} / \mathrm{d}$ (fig. 21A); this well produced a corresponding transmissivity value of 430,000 $\mathrm{ft}^{2} / \mathrm{d}$. Two wells in Berrien County, Ga., penetrate about $600-700 \mathrm{ft}$ of aquifer thickness and produce transmissivity values of about $360,000 \mathrm{ft}^{2} / \mathrm{d}$ (Kellam and Gorday, 1990). The lithologic description of one of these wells lists a 17-ft zone of no samples located at the top of the Ocala Limestone (McFadden and others, 1986, p. 92), most likely the result of solution cavities, which caused poor sample return. By comparison, a well located in the Gulf Trough-Apalachicola Embayment region south of Moultrie, Colquitt County, Ga., produced a transmissivity value of about $89,000 \mathrm{ft}^{2} / \mathrm{d}$ from about $600-700 \mathrm{ft}$ of aquifer thickness. Construction records associated with this well indicate that most of the production of about $600 \mathrm{gal} / \mathrm{min}$ was derived from a 40-ft zone of soft limestone penetrated at a depth of 425-465 ft below land surface (by S.B. Milligan, Jr., then resident engineer, E.P. McLean Engineering Company, to W.F. Ladson, then City Manager, City of Moultrie, Ga., written commun., January 29, 1949). Most likely, the Suwannee Limestone of the Upper Floridan aquifer supplied water to this well. Other high values of transmissivity in the range $100,000-600,000 \mathrm{ft}^{2} / \mathrm{d}$, attributed to limestone dissolution, occur in Berrien, Coffee, and Cook Counties, Ga. (Kellam and Gorday, 1990), and in Hamilton County, Fla. (Ceryak and others, 1983).

\section{Storage Coefficient and Specific Yield}

Storage properties of the Upper Floridan aquifer vary by several orders of magnitude in the ASO River Basin and surrounding area depending on the degree of limestone dissolution and whether groundwater occurs under confined or unconfined conditions. Confined- (or artesian-) aquifer conditions use the storage coefficient and occur when the groundwater level exceeds the top of the aquifer; unconfinedor water-table-aquifer conditions use the specific yield and occur when the groundwater level lies below the top of the aquifer. Various degrees of semiconfined (leaky artesian) to confined conditions cause storage coefficient values to vary by several orders of magnitude in the Upper Floridan aquifer. This variability of storage coefficient values causes differences in vertical-leakage rates through the upper semiconfining unit during non-steady, or transient, groundwater flow. Results of aquifer testing in the study area and in coastal Georgia indicate that values for the confined (or artesian) storage property, or storage coefficient, range from 0.00004 to 0.04 (Clarke and others, 2005).

For unconfined, or water-table, conditions, the specific yield controls the release or uptake of water by the aquifer. In contrast to storage-coefficient values, a value of 0.1 derived from an aquifer-performance test in Bainbridge, Ga. (Sever, 1965), located a few miles to the west of the ASO River Basin (fig. 1), indicates unconfined conditions in the Upper Floridan aquifer.

The position of the groundwater level relative to the top of the aquifer determines which storage property controls the release or uptake of groundwater during transient groundwater flow. Seasonal or short-term water-level fluctuations can cause aquifer conversion between artesian and water-table conditions. Unconfined conditions also occur where erosion has removed the upper semiconfining unit and surficial aquifer system from overlying the Upper Floridan aquifer (fig. 15). Where erosion exposes the aquifer at or near land surface, the aquifer contains a water table that reflects a subdued expression of topography.

Pumping, climatic conditions, and exchange with surface water cause temporal variations in groundwater levels on local and regional scales throughout the basin which, in turn, can cause conversion from confined to unconfined, or from unconfined to confined conditions depending on the type, extent, and duration of hydrologic stress or change in stress imposed on the Upper Floridan aquifer. Transient groundwater flow occurs at the onset of hydrologic stress applied to the aquifer or whenever rates of existing hydrologic stress change, such as (1) during the initial stages of pumping or changes in pumping rates, (2) during changes in stream stage and (or) groundwater level that control groundwater and surface-water exchange, or (3) during changes in recharge by infiltration of precipitation or vertical leakage. Water is released from or taken up into storage in the aquifer according to the artesian or water-table storage properties as groundwater levels adjust to changes in hydrologic stress, such as those described. 


\section{A. Hydraulic conductivity}
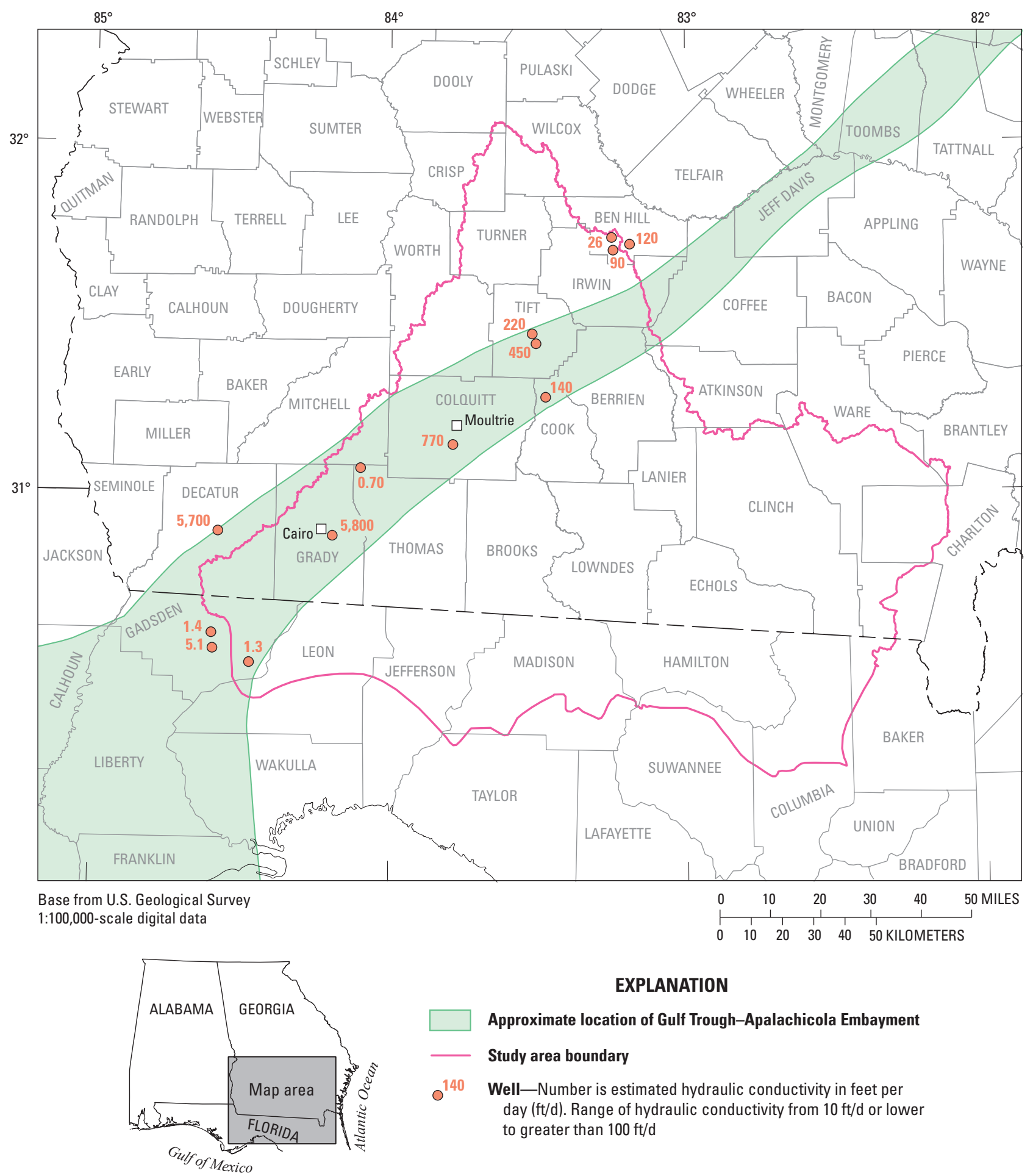

EXPLANATION

Approximate location of Gulf Trough-Apalachicola Embayment

Study area boundary

Well-Number is estimated hydraulic conductivity in feet per day (ft/d). Range of hydraulic conductivity from $10 \mathrm{ft} / \mathrm{d}$ or lower to greater than $100 \mathrm{ft} / \mathrm{d}$

Figure 21. Hydraulic properties of the Upper Floridan aquifer in the Aucilla-Suwannee-Ochlockonee River Basin $(A)$ hydraulic conductivity and $(B)$ transmissivity (modified from Ceryak and others, 1983; Bush and Johnston, 1988; Kellam and Gorday, 1990; and McConnell and Hacke, 1993). 


\section{B. Transmissivity}
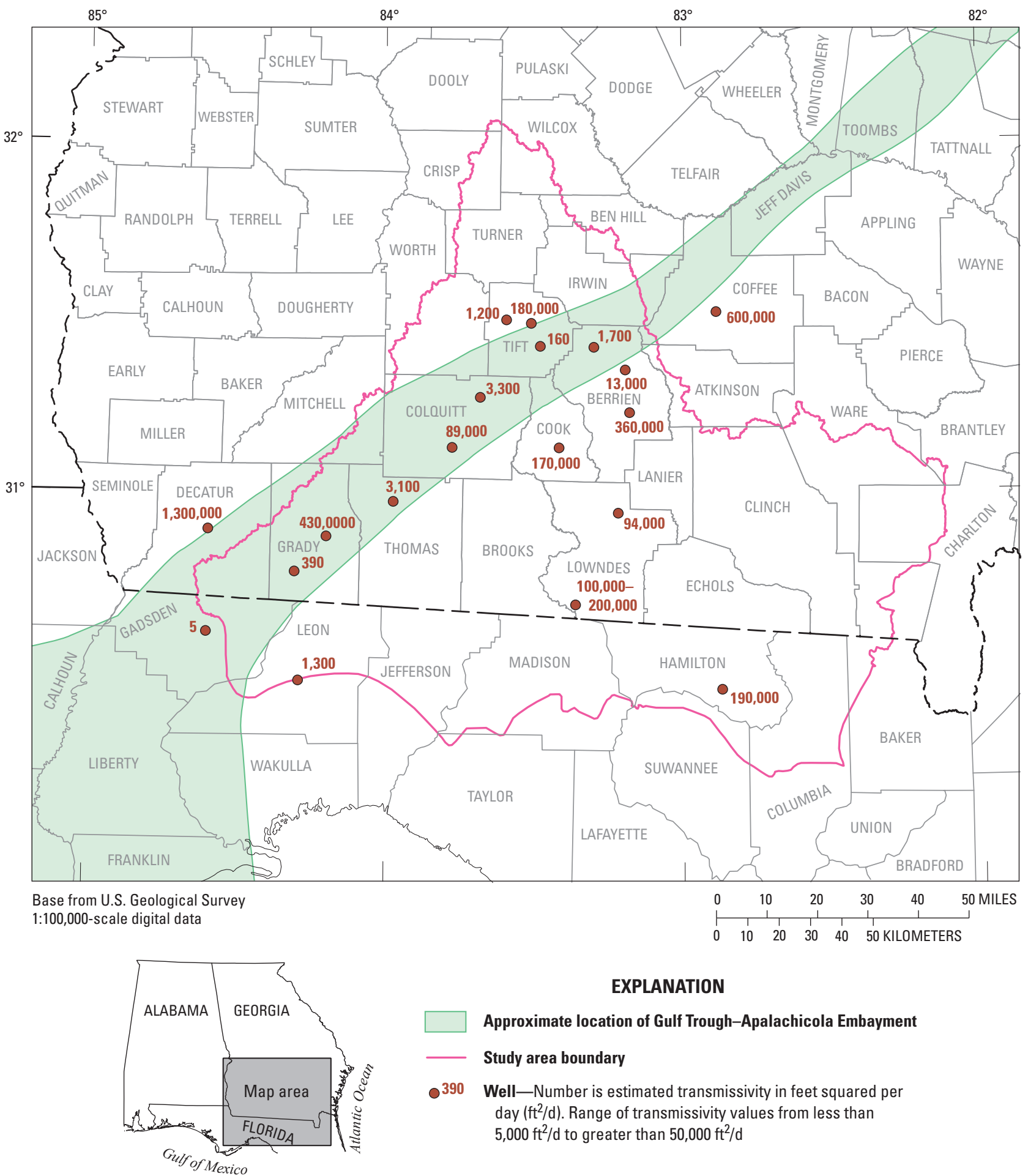

\section{EXPLANATION}

\section{Approximate location of Gulf Trough-Apalachicola Embayment}

\section{Study area boundary}

Well—Number is estimated transmissivity in feet squared pe day $\left(\mathrm{ft}^{2} / \mathrm{d}\right)$. Range of transmissivity values from less than $5,000 \mathrm{ft}^{2} / \mathrm{d}$ to greater than $50,000 \mathrm{ft}^{2} / \mathrm{d}$

Figure 21. Hydraulic properties of the Upper Floridan aquifer in the Aucilla-Suwannee-Ochlockonee River Basin $(A)$ hydraulic conductivity and (B) transmissivity (modified from Ceryak and others, 1983; Bush and Johnston, 1988; Kellam and Gorday, 1990; and McConnell and Hacke, 1993).-Continued 


\section{Groundwater Levels and Fluctuations}

Annually, groundwater levels in the Upper Floridan aquifer respond to normal hydrologic stress, such as seasonal precipitation and groundwater pumping, and to unseasonable or abnormal hydrologic stress caused by climatic and (or) pumpage extremes. Groundwater levels attain a seasonal high during early spring because the combination of infiltrating precipitation, low irrigation demand, and low evapotranspiration rates raises groundwater levels from the low water-level conditions of the previous season (fig. 22). Groundwater levels decline from late spring to early fall in response to increased irrigation pumpage and evapotranspiration, and decreased infiltration of precipitation from rates in early spring. Summertime convective storms produce high-intensity, shortduration precipitation events that cause more runoff and less infiltration to recharge groundwater levels than the relatively long-duration, low-intensity storms associated with frontal passages during mid-fall to early spring. The long duration, low-intensity storms cause low runoff and high infiltration conducive to recharging groundwater levels. Precipitation during the growing season temporarily curtails irrigation pumpage and slows the seasonal decline in groundwater level until dry conditions cause pumping to resume. Groundwater levels rise by year's end and continue rising into the following spring in response to seasonal precipitation beginning during mid-fall and extending into early spring.

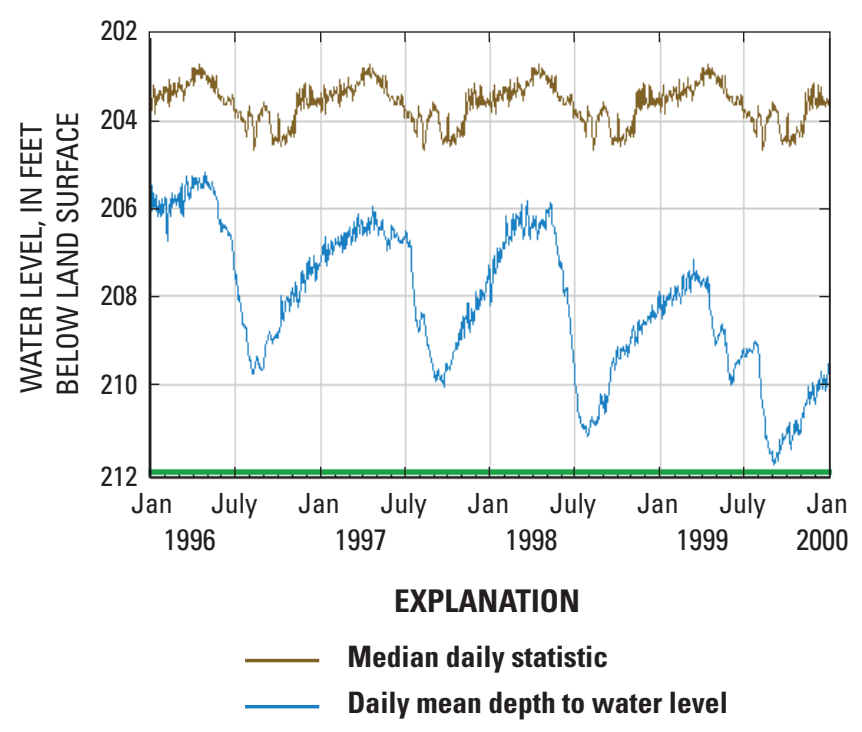

Figure 22. Hydrograph showing seasonal groundwater-level fluctuation in well 15L020, Sylvester, Georgia, 1996-1999.
In the absence of unseasonable climatic and/or pumpage variability, groundwater levels usually fluctuate within the range of previous years' levels, rising to nearly the same seasonal-high values each spring and declining to about the same seasonal-low values each fall. Daily median, or 50th percentile, groundwater levels, computed for the period of record and superposed on a hydrograph showing daily mean groundwater levels (fig. 22), define "normal" seasonal fluctuations and allow comparison of daily mean groundwater levels to a statistical representation of normal conditions. Small deviations from the median statistic indicate typical variations in groundwater levels caused by normal climatic variability and short-term changes in hydrologic stress. Consistently increasing or decreasing high or low groundwater levels in relation to the median daily statistic indicate a trend in groundwater levels that requires explanation with regard to changes in climate or hydrologic stress that might signal an irreversible groundwater-level condition. For example, the hydrograph of well 15L020 during 1996-1999 indicates a declining trend in groundwater level of about $6 \mathrm{ft}$ in 4 years, or an average yearly groundwater-level decline of about $1.5 \mathrm{ft}$. The significance of this decline is evaluated with regard to a period of observation and hydrologic stresses that have changed during this time, as discussed below.

Hydrographs from continuous-recorder wells completed in the Upper Floridan aquifer depict varying magnitudes of seasonal groundwater-level fluctuations in the ASO River Basin (fig. 23). Unseasonable climate and (or) pumpage variations either amplify or diminish groundwater-level fluctuations from normal conditions, depending on the severity and duration of the climatic and (or) pumpage variation. Multiseason or multiyear deviations from normal climatic conditions and (or) pumping rates cause rising or declining groundwater-level trends, evidenced on the hydrographs as divergence of groundwater levels from median values. Rising or declining groundwater-level trends affect groundwater and surface-water exchange and recharge and discharge relations between hydrologic components that contribute to the water resources of the basin (fig. 13).

Consistent deviation from normal seasonal groundwaterlevel fluctuations could indicate a rising or declining trend in groundwater levels triggered by a corresponding increase or decrease in hydrologic stress on the Upper Floridan aquifer. Dry climatic conditions during the fall and winter hinder recovery of groundwater levels, and groundwater levels that do not recover from seasonal-low values in the fall begin the spring at a lower level than the previous year. Consistently dry conditions during periods of aquifer recharge - mid-fall through early spring - cause lower groundwater levels each spring than during the previous spring and could signal a declining groundwater-level trend. Low-groundwater-level conditions that occur during late spring continue throughout the year to perpetuate the declining groundwater-level trend. 
A. Well 12F036, 1964-2008

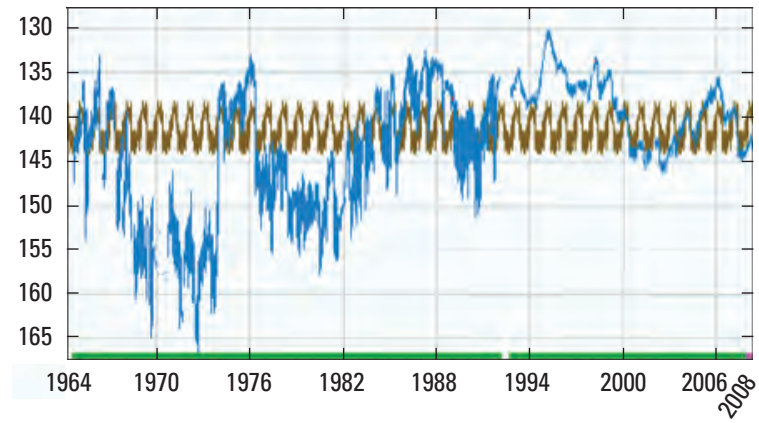

C. Well 18H016, 1965-2008

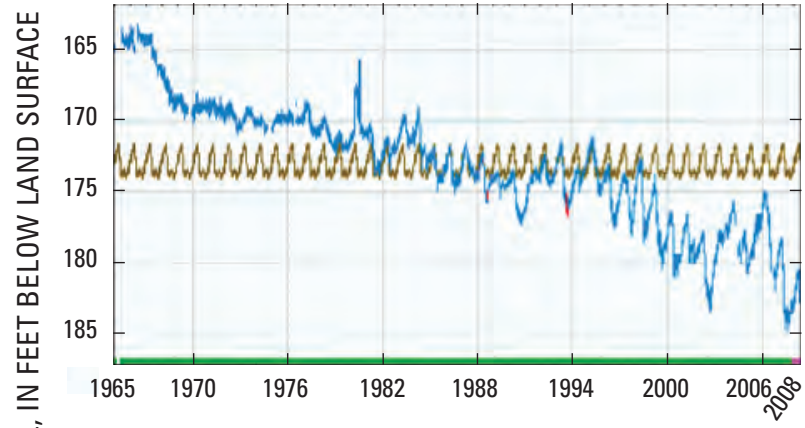

E. Well 19E009, 1957-2008

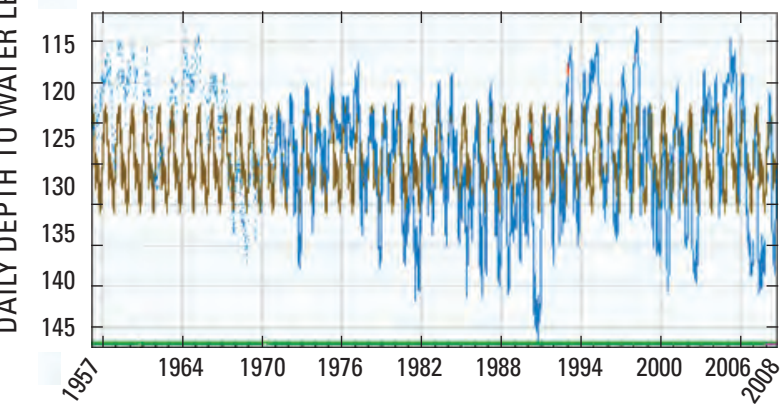

G. Well 27G003, 1982-2008

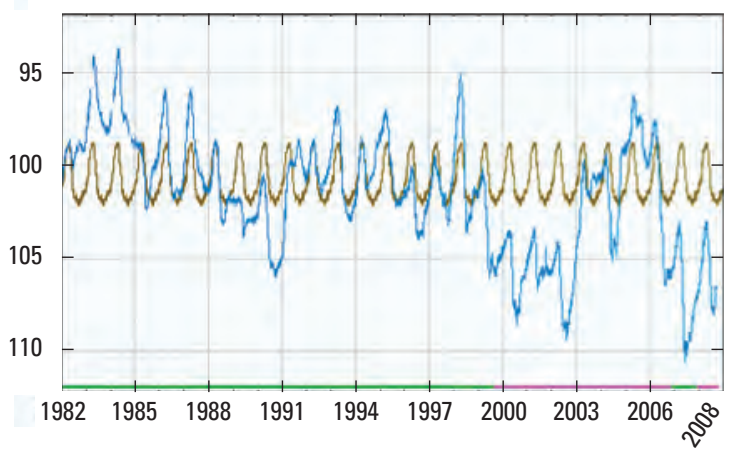

B. Well 15L020, 1972-2008

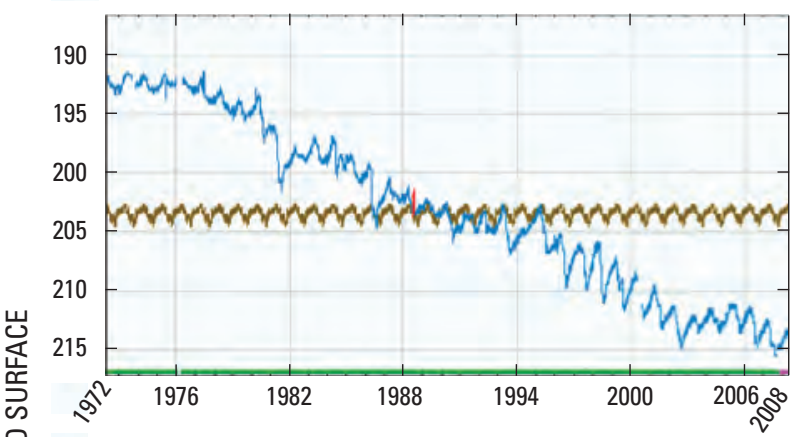

D. Well 18K049, 1978-2008

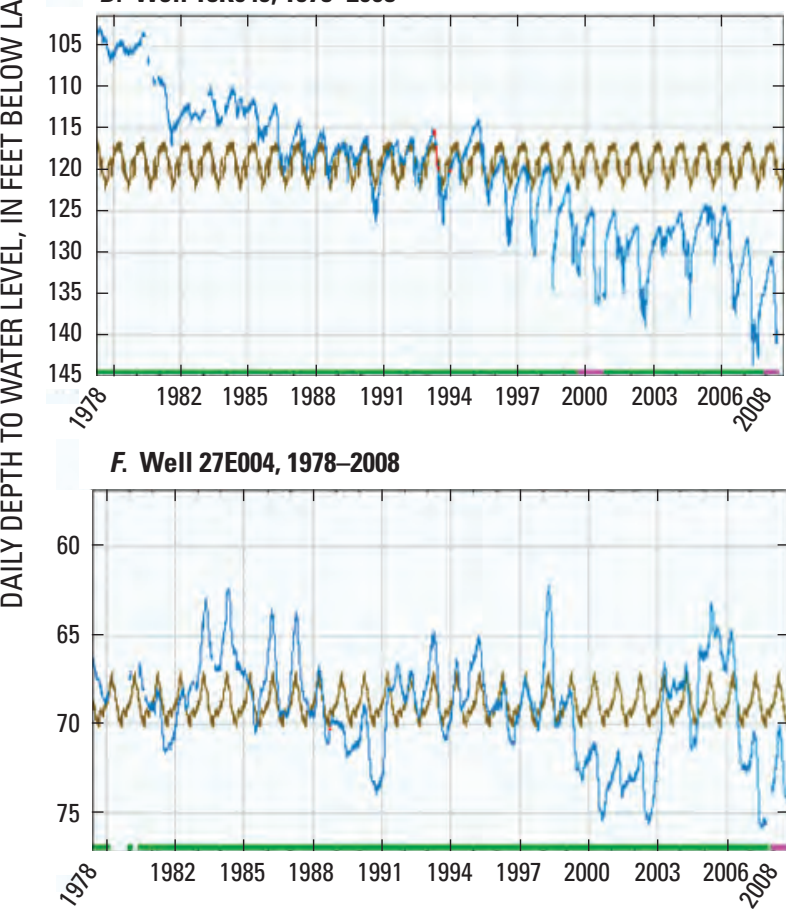

\section{EXPLANATION}

\section{Median daily statistic}

Daily mean depth to water level

Estimated daily mean depth to water level

Period of approved data

Period of provisional data

Figure 23. Hydrographs showing daily mean depth to water level and period-of-record median daily groundwater level for wells $(A)$ 12F036, 1964-2008; (B) 15L020, 1972-2008; (C) 18H016, 1965-2008; (D) 18K049, 1978-2008; (E) 19E009, 1957-2008; (F) 27E004, 1978-2008; and (G) 27G003, 1982-2008. 
The effectiveness of precipitation to raise groundwater levels the Upper Floridan aquifer varies in the basin, depending on the type and thickness of overlying sediment and degree of hydraulic connection of the aquifer with land surface or surface water (fig. 15). Although thickness of the overlying material can control water-level recovery by affecting infiltration of precipitation, regional pumpage and climatic conditions also influence water-level recovery. High-precipitation months do not necessarily generate high groundwater levels, especially in areas where relatively thick overburden hydraulically disconnects the aquifer from land surface and limits recharge by infiltration of precipitation. Similarly, the magnitude of precipitation that occurs near each well during the fall through early spring does not always affect the magnitude of seasonal water-level recovery if infiltrating precipitation first satisfies a thick unsaturated zone in the overburden before reaching the Upper Floridan aquifer.

Unseasonably frequent or high precipitation during the growing season can reduce or eliminate seasonal groundwaterlevel decline even in areas where a relatively thick upper semiconfining unit limits or prevents recharge to the aquifer. Irrigation pumping rates usually decrease during wet periods of the growing season, causing less pumpage-induced groundwater-level decline than during normal or dry periods. Climatic variation triggers changes in agricultural pumping rates, which increase during periods of low precipitation, lowering unseasonably low groundwater levels, and decrease during periods of high precipitation, reducing or eliminating groundwater-level declines.

Groundwater levels in continuous recorder wells completed in the Upper Floridan aquifer responded to regional drought during 1980-1981, 1986, 1998-2002, and 2006 (figs. 23A-F). The hydrograph of continuous recorder well 27G003 (fig. 23G) showed effects of regional drought conditions similar to groundwater levels in wells previously cited, except that the period of record began during 1982 and, therefore, did not exist to record drought conditions during 1980-1981. Some climatological stations recorded above-normal precipitation during a few months of 1986 and 2001, which were drought years, and during 1987 following the drought of 1986 (table 3, as noted). Conversely, all observation wells exhibited unseasonably high groundwater levels during 1987, although some climatological stations located near the observation wells recorded less-thanaverage precipitation.

Annual precipitation during 1986, 1987, and 2001, recorded at climatological stations located near continuous recorder wells, compared favorably with the period-of-record mean-annual precipitation (table 3), which seems to refute that drought conditions ever occurred during two of these years. Unseasonably high precipitation during specific months of these years skewed total annual precipitation to near meanannual values. Groundwater levels seemed to respond more to regional climatic conditions than to local conditions, as evidenced by the low water levels recorded on well hydrographs during drought years (fig. 23).
Declining groundwater-level trends of any duration indicate a systematic lowering of the potentiometric surface of the Upper Floridan aquifer and a depletion of groundwater resources, compared with previous conditions (fig. 23). Abnormally dry climatic conditions reduce infiltration of precipitation to the Upper Floridan aquifer from conditions of normal precipitation, limiting aquifer recharge and causing unseasonably low groundwater levels in recharge areas of the Upper Floridan aquifer, such as along the northwestern basin boundary and in karst areas along the Georgia-Florida State line and to the south and east of the Gulf Trough-Apalachicola Embayment. Drought-induced increases to irrigation pumping rates cause declining groundwater-level trends wherever pumping stresses the Upper Floridan aquifer beyond its ability to recharge by regional groundwater flow, infiltration of precipitation, or induced surface-water leakage. Unseasonably low groundwater levels in aquifer-recharge areas, in turn, lower hydraulic gradients and regional groundwater-flow rates in downgradient, or outward, directions from the recharge area.

Rising groundwater-level trends of any duration can result from a reduction of hydrologic stress to the aquifer, such as above-normal precipitation sustained during several seasons or years and (or) pumpage reduction or relocation, and represent an accretion of groundwater resources. In a reverse process from that previously described for declining groundwater-level trends, precipitation that infiltrates areas favorable for recharge to the Upper Floridan aquifer (fig. 15) locally raises groundwater levels, increases regional groundwater flow out of recharge areas, and raises downgradient groundwater levels. Relocation of municipal pumpage at Cairo, Ga., for example, during October 1973 caused a 25-ft rise in the groundwater level in well 12 F036 by February 1974 (fig. 23A). A declining trend during 1976-1982 negated this water-level increase; however, a rising trend in groundwater levels during the next 6 years restored water levels to the 1976 level by 1988 . The hydrograph for well 15L020 (fig. 23B) depicts other groundwater-level trends during 1988-1991 (declining), 1991-1995 (rising), and 1995-2003 (declining), characterized by amplified seasonal water-level fluctuations that exceeded median values.

\section{September 2006 Potentiometric Surface}

Potentiometric contours of the Upper Floridan aquifer during September 2006 indicated complex patterns of groundwater flow in the ASO River Basin and across the basin boundary in the ACF River Basin (fig. 24). Groundwater generally flows southward to Florida and the Gulf of Mexico and eastward to coastal Georgia and the Atlantic Ocean from a groundwater divide located along the northern and western boundary of the ASO River Basin with the ACF River Basin (fig. 24B). Groundwater mounds near the Withlacoochee River in Brooks and Lowndes Counties, Ga., and groundwater depressions in southern Colquitt and Cook Counties, Ga., define diverging and converging groundwater-flow patterns, respectively, indicative of recharge and discharge, which alter the regional pattern of southward and eastward groundwater flow. 
Table 3. Precipitation for selected years and climatological stations located in the Aucilla-Suwannee-0chlokonee River Basin.

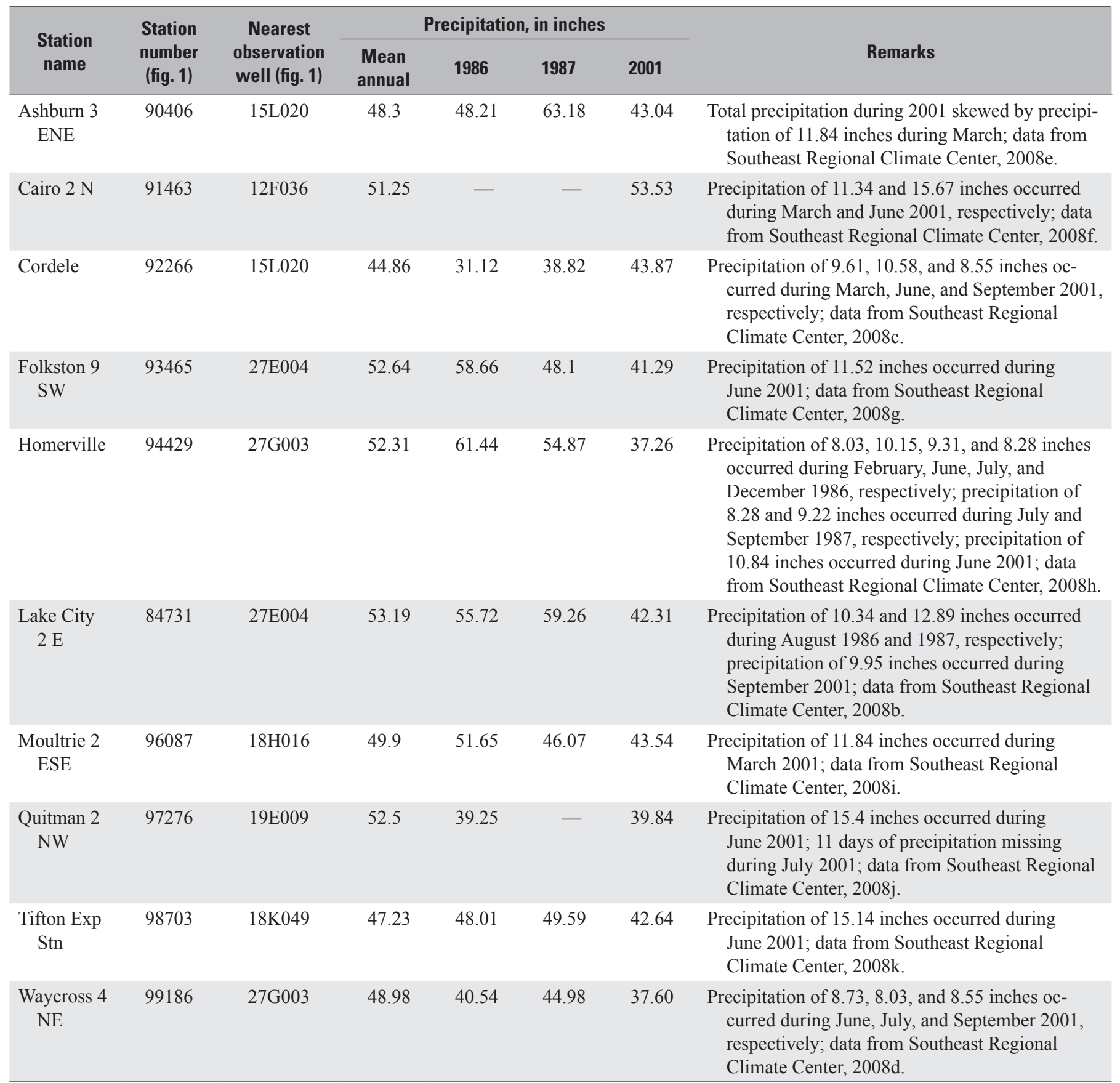



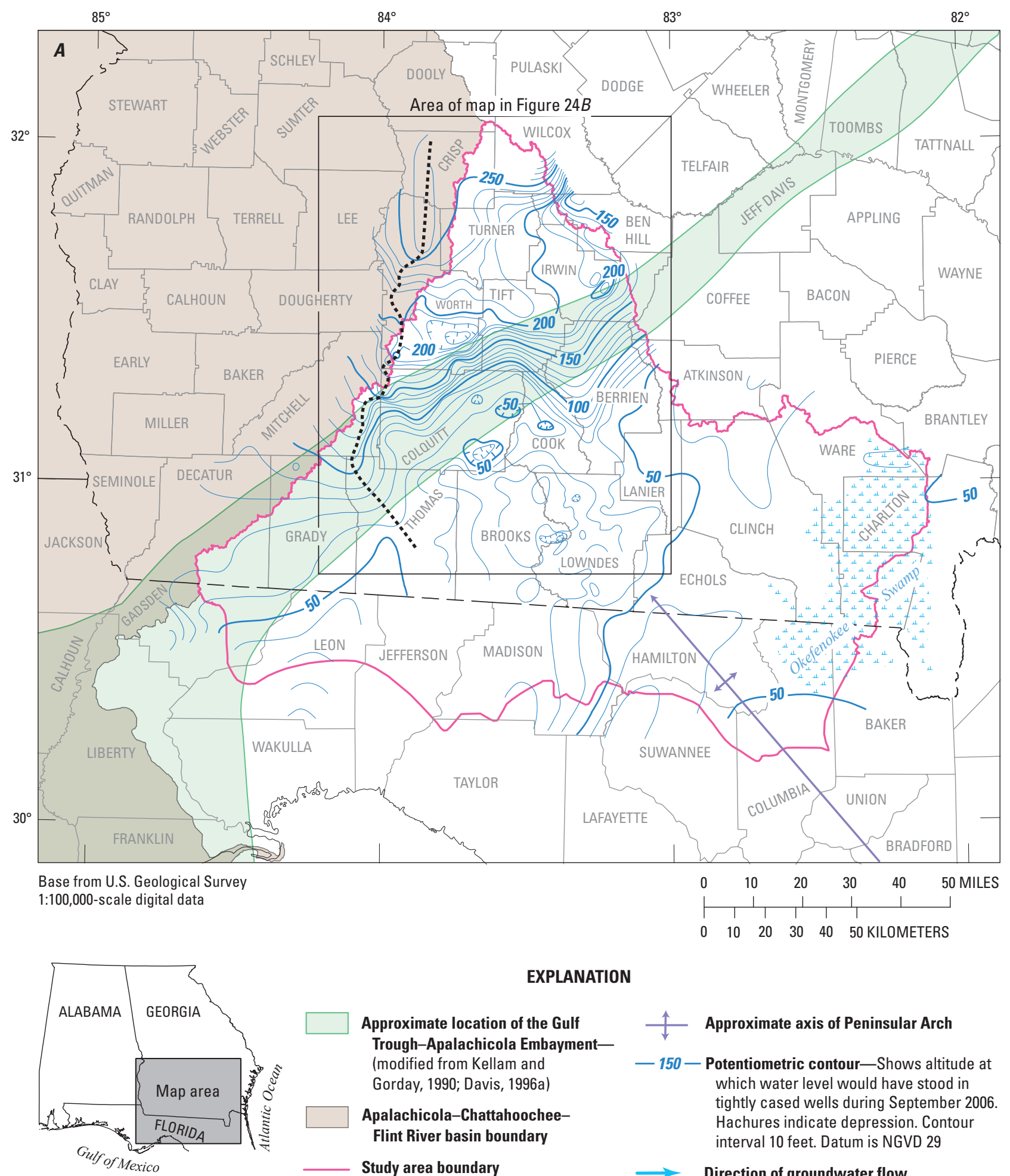

EXPLANATION

Approximate location of the Gulf Trough-Apalachicola Embayment(modified from Kellam and Gorday, 1990; Davis, 1996a)

Apalachicola-ChattahoocheeFlint River basin boundary

Study area boundary

Groundwater divide

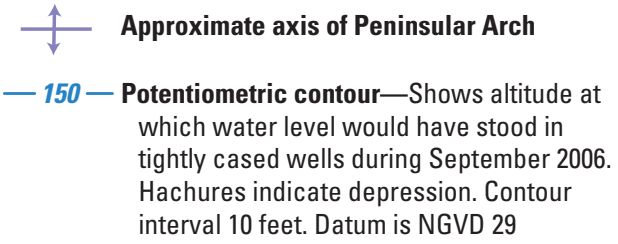

Direction of groundwater flow

Figure 24. (A) Potentiometric surface of the Upper Floridan aquifer in southern Georgia and northern Florida, September 2006; and $(B)$ enlarged view of the potentiometric surface of the Upper Floridan aquifer in southern Georgia, September 2006, showing groundwater divide and flow directions. 


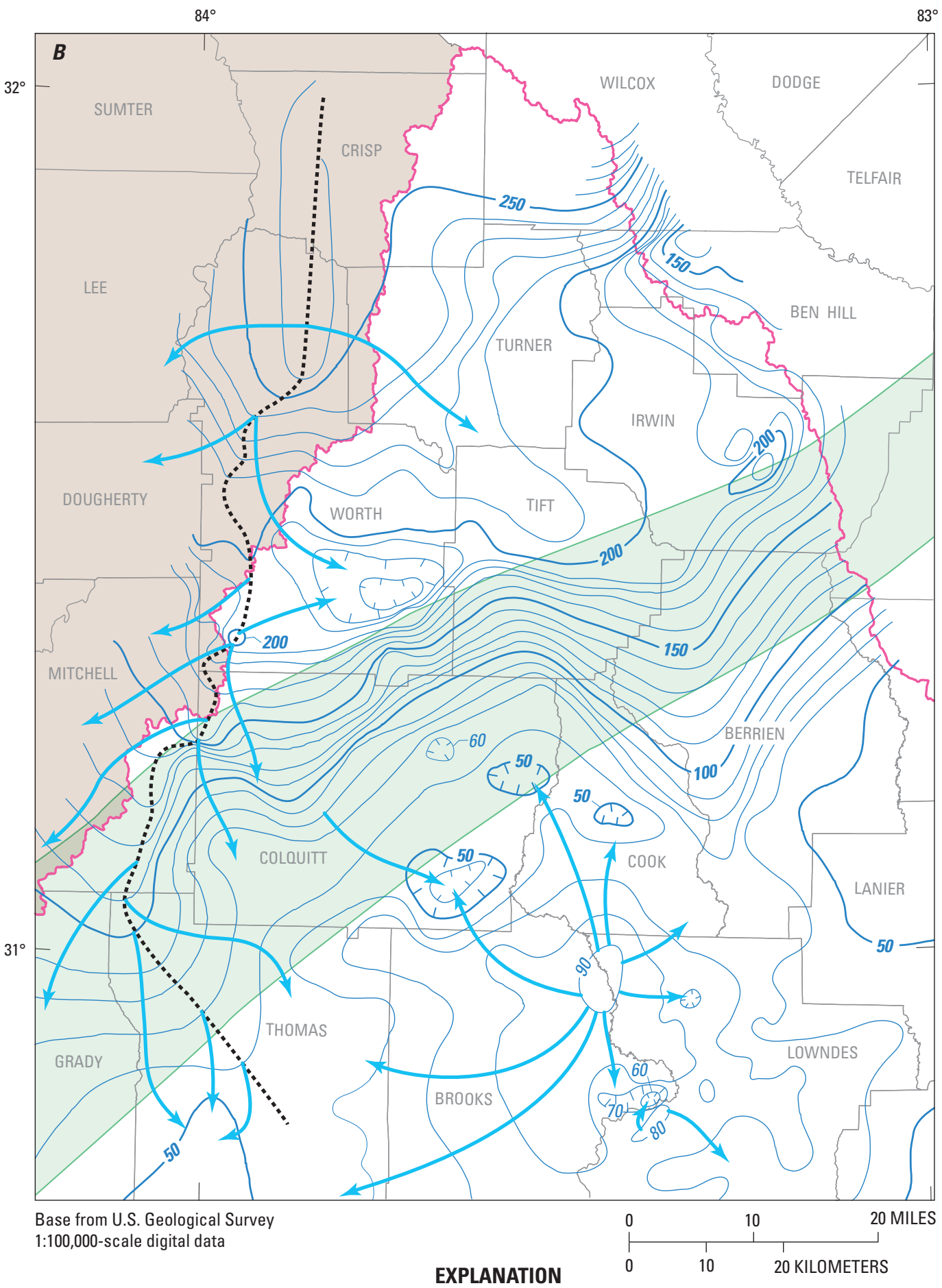

Approximate location of the Gulf TroughApalachicola Embayment-(modified from Kellam and Gorday, 1990; Davis, 1996a)

Apalachicola-Chattahoochee-Flint River basin boundary

\section{_ Study area boundary}

Groundwater divide $\uparrow$ Approximate axis of Peninsular Arch

- 150 - Potentiometric contour-Shows altitude at which water level would have stood in tightly cased wells during September 2006 Hachures indicate depression. Contour interval 10 feet. Datum is NGVD 29

Direction of groundwater flow

Figure 24. (A) Potentiometric surface of the Upper Floridan aquifer in southern Georgia and northern Florida, September 2006; and $(B)$ enlarged view of the potentiometric surface of the Upper Floridan aquifer in southern Georgia, September 2006, showing groundwater divide and flow directions.-Continued 
Southward bending of the $60-190-\mathrm{ft}$ potentiometric contours established a groundwater divide east of the basin boundary in the ASO River Basin in Colquitt, Grady, Mitchell, Thomas, and southern Worth Counties (fig. 24B). In Decatur and Grady Counties, Ga., and in Gadsden and Leon Counties, Fla., the $60-90-\mathrm{ft}$ potentiometric contours trend nearly east to west across the basin boundary defining southward groundwater flow from the ACF River Basin into the ASO River Basin (fig. 24A). The northwestern trend of the 100-150-ft potentiometric contours across the basin boundary indicates southwestward groundwater flow along the basin boundary in southern Mitchell County. The 160-190-ft potentiometric contours align more northward than the 100-150-ft contours, indicating westward groundwater flow across the basin boundary from the ASO River Basin into the ACF River Basin in northwestern Colquitt and southwestern Worth Counties.

The 210-260-ft potentiometric contours during September 2006 positioned the groundwater divide in the ACF River Basin west of the basin boundary in central Crisp and northern Worth Counties (fig. 24B). Groundwater flows eastward to southeastward into the ASO River Basin from the ACF River Basin in northern and central Worth County. The 200-ft potentiometric contour positioned the groundwater divide coincident with the basin boundary in southern Worth County where groundwater diverges from the divide and basin boundary and flows into both basins.

Tightly spaced 70-190-ft contours on the September 2006 potentiometric surface defined high hydraulic gradients but relatively slow-moving groundwater in the Gulf TroughApalachicola Embayment area (fig. 24A). Low hydraulic conductivity and transmissivity in the trough-embayment area (fig. 21) limit southeastward groundwater flow from recharge areas across the basin boundary in the ACF River Basin in the northwestern part of the study area.

Closed patterns of 40- and 50-ft cotours on the September 2006 potentiometric surface located southeast of the Gulf Trough-Apalachicola Embayment region in eastern Colquitt and Cook Counties defined depressions that indicate groundwater discharge (fig. 24A). The depression in southeastern Colquitt County coincides with northeastern extensions of the Ochlockonee fault and Barwick arch, as identified by Sever (1966) (fig. 9). Miocene folding and faulting displaced the Upper Floridan aquifer upward by as much as $190 \mathrm{ft}$ on the southeastern side of the fault, juxtaposing the top unit of the aquifer (the Suwannee Limestone) with the low-water-bearing Tampa Limestone on the northwestern side of the fault. "Rocks on the southeast side of the fault [have been] upthrown with the amount of displacement increasing [from Thomas County] to the northeast" (Sever, 1966, p. 8). Sever (1966) described a condition in Thomas County during March 1964 where the groundwater level of the Suwannee Limestone was 10-20 ft higher than groundwater levels of the underlying Byram Formation, Marianna Limestone equivalent, and Ocala Limestone (fig. 4). Very little groundwater flowed across the Ochlockonee fault. Rather, groundwater flowed down the fault into underlying geologic units.
The depression in the September 2006 potentiometric surface in southeastern Colquitt County (fig. 24A) coincided with the location of a recharge mound during December 1969, where groundwater diverged from an area enclosed by 80- and 90-ft potentiometric contours (Zimmerman, 1977, fig. 5). A groundwater level of 80-90 ft during December 1969 coincided with the top altitude of the Upper Floridan aquifer in this area (fig. 16). Therefore, groundwater levels of 40-50 ft during September 2006 indicated that about 40-50 ft of aquifer dewatering had occurred since December 1969. Such dewatering can lead to depletion of the groundwater resource as saturated aquifer thickness decreases with increased dewatering. Other depressions in the September 2006 potentiometric surface seem to be pumpage related rather than indicative of vertically downward leakage from the Suwannee Limestone to deeper geologic units of the Upper Floridan aquifer.

Closed 80-90-ft contours of the September 2006 potentiometric surface located in Brooks and Lowndes Counties defined diverging groundwater flow indicative of recharge mounds in the Upper Floridan aquifer (fig. 24). In these areas, the aquifer lies near or slightly below land surface because of uplift by the northern extension of the Peninsular Arch and subsequent erosion of overlying sediments. Limestone dissolution formed sinkholes and other karst features in this area that promote infiltration of precipitation and surface-water exchange (Krause, 1979).

Sparse groundwater-level measurements in the eastern part of the study area during 2006 resulted in a general potentiometric surface defined by widely spaced 40 - and $50-\mathrm{ft}$ potentiometric contours (fig. 24A). This area contains the Okefenokee Swamp, where more than $300 \mathrm{ft}$ of low-waterbearing clastic sediments overlie the Upper Floridan aquifer (fig. 15), limiting if not eliminating hydraulic connection of the aquifer with land surface and surface water.

\section{Lower Confining Unit}

The Lisbon Formation defines the lower confining unit of the Upper Floridan aquifer in the northern, western, and northcentral parts of the study area (Miller, 1986). The carbonaceous clay and glauconitic limestone of the Lisbon Formation that, in turn, grades into micritic, low-permeability, finely pelletal limestone interbedded with fine-to-medium crystalline, slightly vuggy dolomite of the Avon Park Formation to the south and east in the ASO River Basin represents an important subregional confining unit within the Floridan aquifer system (Miller, 1986). These geologic units define the lower confining unit to the Upper Floridan aquifer (fig. 4) and create a hydrologic barrier to groundwater flow. The lower confining unit prevents poor-quality water in deeper water-bearing units from entering the Upper Floridan aquifer in the study area.

Thickness of the lower confining unit varies greatly in the ASO River Basin (figs. 7, 8, 10-12). At least $100 \mathrm{ft}$ of the Lisbon Formation extends from the western boundary with the ACF River Basin, across the Gulf Trough-Apalachicola 
Embayment region, northeastward to northern Coffee County, Ga., just to the northeast of the study area Miller (1986) (fig. 6). The lower confining unit increases in thickness southeastward from about $500 \mathrm{ft}$ in Coffee County to more than 2,200 $\mathrm{ft}$ in Clinch County, Ga., in the eastern part of the study area. Thickness of the lower confining unit increases northeastward from about 200-300 ft in Madison County, Fla., to nearly 2,000 ft in Echols County, Ga. (figs. 10 and 12). The low stratigraphic position of these low permeable units in the southeastern part of the study area (fig. 12) creates the base of the Floridan aquifer system, above which a local confining unit about 100-150-ft thick separates the Upper Floridan aquifer from permeable units of the Lower Floridan aquifer.

\section{Conclusions}

The objectives addressed in this report are restated from the section "Purpose and Scope" prior to each conclusion.

1. Describe the lithologic and hydraulic properties of the Upper Floridan aquifer and hydraulically connected geologic units that would enable assessment of water exchange between Upper Floridan aquifer and other geohydrologic units and surface water.

Tectonic forces underlying the Coastal Plain played a major role in determining the type of sediment in the $20,000-\mathrm{ft}$ sequence of clastic and carbonate sediments deposited in the ASO River Basin. Structural control of sedimentation also affected the geohydrology and water exchange of geohydrologic units with surface water. Differential compaction and limestone dissolution and collapse affected the accumulation and lithology of late-middle Eocene and younger sediments constituting the surficial aquifer system, Upper Floridan aquifer, and intervening upper semiconfining unit. An early Mesozoic uplift, the Peninsular Arch, established various depocenters along its flanks and dominated sedimentation patterns throughout most of the study area. Deposition and accumulation of more than $300 \mathrm{ft}$ of low-permeability clastic sediments on the northeastern flank of the Peninsular Arch in the Southeast Georgia Embayment and Suwannee Strait, and along the northwestern flank of the Arch in the Gulf Trough-Apalachicola Embayment, virtually isolated the Upper Floridan aquifer from land surface and recharge by infiltrating precipitation. Burial of limestone beneath thick clastic overburden in these regions virtually eliminated the potential for ongoing karst processes, resulting in low aquifer hydraulic conductivity and storage coefficient despite increased aquifer thickness of more than $900 \mathrm{ft}$. Accumulation of up to $500 \mathrm{ft}$ of low-water-bearing Oligocene carbonates in the Gulf Trough-Apalachicola Embayment stratigraphically and hydraulically separated two principal water-bearing strata of the Upper Floridan aquifer - the Oligocene Suwannee Limestone and the late Eocene Ocala Limestone. Conversely, uplift and faulting associated with the Peninsular Arch thinned overlying clastic sediments and exposed the Suwannee
Limestone of the Upper Floridan aquifer to land surface near the Florida-Georgia State line, creating a karst region of active limestone dissolution and vigorous exchange of groundwater with surface water.

The Ochlockonee fault and Barwick arch produce more than $100 \mathrm{ft}$ of uplift on the southeastern flank of the Gulf Trough-Apalachicola Embayment, juxtaposing the top of the Upper Floridan aquifer (Suwannee Limestone) with low-water-bearing geologic units of the overlying upper semiconfining unit in Colquitt and Thomas Counties, Ga. Contours of the altitude of geologic units prepared by previous investigators for Colquitt County demonstrate structural control of the top of the Upper Floridan aquifer; disparate values of the aquifer-top altitude within short distances result from deposition and faulting rather than limestone dissolution. Similar data disparities for the top altitude of the Upper Floridan aquifer in Cook County result from variable lithology and water-bearing characteristics of the early Miocene Tampa Limestone, which either transmits water as the top geologic unit of the Upper Floridan aquifer or semiconfines the underlying aquifer, depending on location. Close inspection of geohydrologic data in other counties in the ASO River Basin indicates similar variability of water-transmitting characteristics and presence of geologic units constituting the top of the Upper Floridan aquifer.

2. Develop a hydrogeologic framework and conceptual model for evaluating agricultural pumpage and groundwater and surface-water exchange between the Upper Floridan aquifer and other geohydrologic units connected to surface water.

Various hydrologic processes contribute to groundwater flow in the ASO River Basin, conveying water to pumped wells and facilitating groundwater and surface-water exchange between the Upper Floridan aquifer and other geohydrologic units connected to surface water. Recharge to the Upper Floridan aquifer occurs by infiltration of precipitation, vertical leakage through the surficial aquifer system and undifferentiated overburden, inflow across stream channels or lake bottoms, and regional flow. Discharge processes include vertical leakage, outflow across stream channels or lake bottoms, regional flow, and well pumpage. Geohydrologic units containing these processes consist of the surficial aquifer system, upper semiconfining unit, Upper Floridan aquifer, and lower confining unit. Hydraulic gradients and properties of aquifer transmissivity and storage govern the rate of groundwater flow to pumped wells.

Climate and pumpage changes create complex and dynamic relations with groundwater levels and with groundwater and surface-water exchange in the ASO River Basin. Groundwater levels recover during late fall and winter from declines incurred during the growing season (spring through early fall) caused by high evapotranspiration and runoff, low infiltration of precipitation, and irrigation pumpage. Low evapotranspiration and crop demand during the fall, winter, and early spring coupled with infiltration of precipitation and 
little runoff contribute to raising groundwater levels. Droughts require additional agricultural irrigation pumpage from normal irrigation pumping rates to maintain crop production; increased irrigation pumping rates lower groundwater levels more than would occur during a growing season having normal precipitation. Extended dry or drought conditions lower groundwater levels from normal water-level conditions by reducing recharge to the Upper Floridan aquifer from infiltration of precipitation, from vertical leakage through the upper semiconfining unit and (or) the surficial aquifer system, and from regional flow. Abnormally large groundwater-level declines reduce the base flow of streams and either limit or eliminate hydraulic connection of the aquifer with the stream. Most of the continuous-recorder hydrographs indicate abnormally low groundwater levels during the following years of extremely dry conditions or drought: 1980-81, 1986, 1998-2002, and 2006.

3. Present an overview of 2006 groundwater-level and streamflow hydrologic conditions.

Groundwater levels and streamflows measured during September 2006 provide an overview of then-current hydrologic conditions. Water-table conditions occurred in two areas of the ASO River Basin: north and west of the Gulf TroughApalachicola Embayment region, and south and east of the trough-embayment region but west of the Okefenokee Basin. To the north and west of the trough-embayment region, headwater streams to the Alapaha, Little, and Withlacoochee Rivers incise through relatively thin overburden, further reducing overlying sediment thickness to the Upper Floridan aquifer and enhancing groundwater and surface-water exchange and aquifer recharge. South and east of the trough-embayment region, more than $40 \mathrm{ft}$ of aquifer dewatering occurred since the late 1960s in southeastern Colquitt County, as defined by the area contained within the $40-\mathrm{ft}$ potentiometric contour of the September 2006 potentiometric surface. Here, and in Cook and Thomas Counties, Ga., uplift of Coastal Plain sediments associated with the Peninsular Arch and erosion of Oligocene and younger geologic units positioned the Upper Floridan aquifer near or just below land surface. In karst areas of Brooks and Lowndes Counties, this uplift created a recharge area, water-table conditions, and active groundwater and surface-water exchange along the Withlacoochee River near Valdosta, Ga.

The Upper Floridan aquifer exhibited artesian-aquifer conditions during September 2006 in two distinct areas of the ASO River Basin - along the trace of the Gulf TroughApalachicola Embayment and in the Okefenokee Basin and Swamp. The low-water-transmitting ability of the Upper Floridan aquifer in the trough-embayment region limits groundwater flow, resulting in elevated groundwater levels and artesian conditions in this area. Groundwater levels declined about $100 \mathrm{ft}$ in $20 \mathrm{mi}$ across the trough-embayment region from the northwest to the southeast in northern Colquitt and southern Tift and Worth Counties. Confinement of the Upper Floridan aquifer with up to $300 \mathrm{ft}$ of overburden consisting of the surficial aquifer and upper semiconfining unit causes hydraulic separation of the Upper Floridan aquifer with land surface, limiting recharge, spring discharge, and surface-water exchange from affecting the potentiometric surface and possibly creating water-table conditions. In the Okefenokee Basin and Swamp, limited groundwater development and more than $300 \mathrm{ft}$ of low-water-transmitting overburden limited interaction of the Upper Floridan aquifer with land surface and streams, allowing artesian conditions to exist during September 2006.

\section{Explain hydrologic concepts of the groundwater and surface-water exchange mechanisms that control causal relations between groundwater pumpage in the Upper Floridan aquifer, climatic variations, groundwater-level decline, reductions in streamflow and springflow, and changes in interbasin flow.}

Groundwater levels in the Upper Floridan aquifer and streamflows fluctuate seasonally and exhibit long-term decline in response to complex interactions of natural and humaninduced hydrologic stress imposed on the water resources of the ASO River Basin. Changes in groundwater and surfacewater withdrawal, climatic conditions, and the degree and areal extent of hydraulic connection of the aquifer with land surface and surface water combine to influence groundwater levels and streamflows. Groundwater levels resolve and manifest hydrologic stresses into a unique temporal record: the groundwater hydrograph. Likewise, streamflow and streamflow hydrographs reflect and resolve to varying degrees the combined effects of hydrologic stresses imposed on the groundwater- and surface-water-flow system.

The effect of climate on groundwater levels in the Upper Floridan aquifer varies depending on the potential of the overlying sediment to provide recharge to the aquifer by vertical leakage or by infiltration of precipitation. Increased precipitation above normal amounts raises groundwater levels in the Upper Floridan aquifer above normal, or median, values and increases groundwater recharge and hydrologic processes that deliver water to streams and wells. High-precipitation months do not necessarily coincide with groundwater-level increases shown on hydrographs, however, and the magnitude of precipitation that occurs near each well during fall and winter does not seem to affect the magnitude of groundwaterlevel increases. Storage properties and moisture conditions of the aquifer and overburden sediments can dampen the response of groundwater levels to recharge from infiltration of precipitation in the same manner as storage properties delay pumpage-induced groundwater-level decline.

Increased hydrologic stress caused by dry climatic conditions and (or) increased pumpage initiated a steady groundwater-level decline along the northwestern boundary of the ASO River Basin in Worth County, Ga., during the mid-1970s that extended through the mid-2000s. Increases in center-pivot irrigation systems during the mid-to-late 1990s and drought conditions during the mid-1980s and 1998-2002 contributed to groundwater-level declines indicated on 
hydrographs of wells located in the northwestern and central parts of the study area.

Groundwater-level declines lower the hydraulic gradient toward the ASO River Basin from recharge areas northwest of the basin boundary in the adjacent ACF River Basin and reduce the potential for regional groundwater to flow southeastward across the Gulf Trough-Apalachicola Embayment. Low-water-bearing clastic sediments overlying the Upper Floridan aquifer in the Gulf Trough-Apalachicola Embayment and the low-water transmitting properties of the aquifer in the trough-embayment region divide the ASO River Basin into distinct regions of groundwater flow.

The trough-embayment region restricts recharge in the northwestern parts of the ASO River Basin from flowing southeastward as regional groundwater flow and isolates groundwater-level changes that occur on either side. Waterlevel declines in the trough-embayment region associated with relatively heavy pumping in Colquitt and Tift Counties, Ga., cause local depressions in the potentiometric surface that seem isolated from water levels on the distal side of the trough-embayment region, about 15-20 mi to the northwest. Areas southeast of the trough-embayment region receive insufficient recharge by regional groundwater flow from the northwest, resulting in pumpage-induced groundwater-level declines. Vertical downward leakage of groundwater from the Suwannee Limestone of the Upper Floridan aquifer to deeper limestone units in southeastern Colquitt County, Ga., has caused 40-50 ft of groundwater-level decline and aquifer dewatering since December 1969.

Relatively low aquifer transmissivity in the Gulf TroughApalachicola Embayment region not only limits the effects of pumpage to a local area, but amplifies pumpage-induced groundwater-level changes near pumped wells. For example, the groundwater-level rise during late 1973 to early 1974 in the trough-embayment region near Cairo, Grady County, Ga., represented a local response to relocation of municipal pumpage about 2 mi east of the city. Groundwater-level changes in the trough-embayment region provide unreliable information about groundwater-level trends in other parts of the Upper Floridan aquifer, such as northwest and southeast of the trough-embayment region, as demonstrated by distinct groundwater-level trends on hydrographs of continuousrecorder wells located in these areas.

Groundwater levels exhibited a basin-wide response to regional hydrologic stress imposed on the Upper Floridan aquifer. Hydrographs recorded lowering of groundwater levels in and downgradient from recharge areas in response to extremely dry conditions that occurred during 1980-1981, 1986, 1998-2002, and 2006.

In contrast to pumpage- and drought-induced groundwater-level decline, above-average precipitation following drought conditions raised groundwater levels in recharge areas in the northwestern and south-central parts of the basin. The groundwater-level rise, in turn, raised the potentiometric surface of the Upper Floridan aquifer in the Okefenokee
Basin, although several hundred feet of low-permeability clastic sediments hydraulically isolate the aquifer from infiltrating precipitation and surface-water interaction there. Groundwater-level fluctuations in the eastern part of the ASO River Basin also indicate a strong relation to fluctuations that occur in wells completed in the Upper Floridan aquifer located along the coast.

Declining groundwater-level trends indicate a systematic lowering of the potentiometric surface of the Upper Floridan aquifer and a depletion of groundwater resources, compared with previous conditions. Abnormally dry climatic conditions limit aquifer recharge by infiltration of precipitation from conditions of normal precipitation, causing unseasonably low groundwater levels in recharge areas of the ASO River Basin, such as along the northwestern basin boundary, in karst areas along the Georgia-Florida State line, and south and east of the Gulf Trough-Apalachicola Embayment. Drought-related increases in irrigation pumpage and pumpage associated with increased agricultural, industrial, and (or) municipal development has the potential to cause declining trends in groundwater levels in the Upper Floridan aquifer as pumpage and climatic stress exceed the ability to replenish groundwater resources by regional groundwater flow, infiltration of precipitation, and (or) surface-water leakage. Unseasonably low groundwater levels in aquifer-recharge areas stressed by dry climatic conditions and pumpage cause a lowering of hydraulic gradients and regional groundwater-flow rates in downgradient, or outward, directions from the recharge area. This hydrologic condition has occurred in the Gulf Trough-Apalachicola Embayment region, where dry climatic conditions and increased agricultural pumpage lowered groundwater levels northwest of the trough-embayment region, reducing the potential for groundwater to flow across the trough-embayment region to recharge southeastern parts of the basin.

Groundwater-level decline affects streamflow by reducing hydraulic gradients to streams, thus reducing groundwater discharge to (or base flow of) streams. As groundwater levels attempt to equilibrate to agricultural groundwater withdrawal from the previous growing season, similar effects occur during the current growing season, compounding residual groundwater-level decline and contributing toward a temporal trend of groundwater-level and streamflow decline.

Long-term, groundwater-level decline in the northwestern part of the basin portends diminished water-resource potential for future development. Excessive groundwater-level decline can lower the potentiometric surface of the Upper Floridan aquifer below the top of the geohydrologic unit, which reduces aquifer transmissivity from that associated with artesian conditions, creating water-table and aquifer-dewatering conditions. Aquifer dewatering can degrade groundwater resources by reducing saturated thickness of the aquifer, compacting water-bearing units (subsidence), and collapsing solution-enlarged features that once transmitted groundwater prior to dewatering. 


\section{References Cited}

1,000 Friends of Florida, 2006, accessed November 16, 2006, at http://www.1000friendsofflorida.org/PUBS/Apalachee/ aucilla.asp.

Albertson, P.N., and Torak, L.J., 2002, Simulated effects of ground-water pumpage on stream-aquifer flow in the vicinity of federally protected species of freshwater mussels in the lower Apalachicola-Chattahoochee-Flint River Basin (Subarea 4), southeastern Alabama, northwestern Florida, and southwestern Georgia: U.S. Geological Survey WaterResources Investigations Report 02-4016, 48 p.

Applin, P.L., 1951, Preliminary report on buried pre-Mesozoic rocks in Florida and adjacent states: U.S. Geological Survey Circular 91, $20 \mathrm{p}$.

Applin, E.R., and Applin, P.L., 1964, Logs of selected wells in the coastal plains of Georgia: Georgia Geological Survey Bulletin Number 74, 229 p.

Applin, P.L., and Applin, E.R., 1944, Regional subsurface stratigraphy and structure of Florida and southern Georgia: Bulletin of the American Association of Petroleum Geologists, v. 28, no. 12, p. 1673-1742.

Arthur, J.D., and Rupert, F.R., 1989, Selected geomorphic features of Florida, in The lithostratigraphy and hydrostratigraphy of the Floridan aquifer system in Florida, field trip guidebook T185, Tampa to Tallahassee, Florida, July 1-7, 1989: American Geophysical Union, p. T185:10-14.

Banks, J.E., and Hunter, M.E., 1973, Post-Tampa, pre-Chipola sediments exposed in Liberty, Gadsden, Leon, and Wakulla Counties, Florida: Gulf Coast Association of Geological Societies Transactions, v. 25, p. 122-142.

Bush, P.W., and Johnston, R.H., 1988, Ground-water hydraulics, regional flow, and ground-water development of the Floridan aquifer system in Florida and in parts of Georgia, South Carolina, and Alabama: U.S. Geological Survey Professional Paper 1403-C, 80 p.

Carter, R.F., and Johnson, A.M.F., 1974, Use of water in Georgia, 1970, with projections to 1990: Georgia Department of Natural Resources, Hydrologic Report 2, 74 p.

Ceryak, Ron, 1977, Hydrogeology of a river basin in a karst terrain, Alapaha River, Hamilton County, Florida: Suwannee River Water Management District Information Circular Series IC-5, $20 \mathrm{p}$.

Ceryak, Ron, Knapp, M.S., and Burnson, Terry, 1983, The geology and water resources of the upper Suwannee River Basin, Florida: Florida Bureau of Geology Report of Investigations No. 87, 165 p.
Chen, C.S., 1965, The regional lithostratigraphic analysis of Paleocene and Eocene rocks of Florida: Florida Geological Survey Bulletin 45, $105 \mathrm{p}$.

Clark, W.Z., and Zisa, A.C., 1976, Physiographic map of Georgia: Georgia Geologic Survey, OM-8.

Clarke, J.S., Leeth, D.C., Taylor-Harris, DáVette, Painter, J.A., and Labowski, J.L., 2005, Summary of hydraulic properties of the Floridan aquifer system in coastal Georgia and adjacent parts of South Carolina and Florida: U.S. Geological Survey Scientific Investigations Report 2004-5264, 54 p.

Cooke, C.W., 1939, Scenery of Florida interpreted by a geologist: Florida Geological Survey Bulletin 17, 118 p.

Cooke, C.W., 1943, Geology of the Coastal Plain of Georgia: U.S. Geological Survey Bulletin 941, 121 p.

Cox, J.A., Baker, W.W., and Engstrom, R.T., 2001, Red-cockaded woodpeckers in the Red Hills regionA GIS-based assessment: Wildlife Society Bulletin, v. 29, no. 4 , p. $1278-1288$.

Crandall, C.A., Katz, B.G., and Hirten, J.J., 1999, Hydrochemical evidence for mixing of river water and groundwater during high-flow conditions, lower Suwannee River basin, Florida, USA: Hydrogeology Journal, v. 7, no. 5, p. $454-467$.

Dall, W.H., and Harris, G.D., 1892, Correlation papersNeogene: U.S. Geological Survey Bulletin 9, 197 p.

Davis, Hal, 1996a, Hydrogeologic investigation and simulation of ground-water flow in the Upper Floridan aquifer of northcentral Florida and southwestern Georgia and delineation of contributing areas for selected city of Tallahassee, Florida, water-supply wells: U.S. Geological Survey WaterResources Investigations Report 95-4296, 61 p.

Davis, M.B., 1996b, Eastern old-growth forests: prospects for rediscovery and recovery: Washington, D.C., Island Press, $400 \mathrm{p}$.

Davis, S.N., and DeWiest, R.J.M., 1966, Hydrogeology: New York, John Wiley and Sons, Inc., 463 p.

Falls, W.F., Harrelson, L.G., Conlon, K.J., and Petkewich, M.D., 2005, Hydrogeology, water quality, and water-supply potential of the Lower Floridan aquifer, coastal Georgia, 1999-2002: U.S. Geological Survey Scientific Investigations Report 2005-5124, 89 p., 1 pl.

Fanning, J.L., 1997, Water use in Georgia by county for 1995: Georgia Geologic Survey Information Circular 101, 95 p.

Fanning, J.L., 2003, Water use in Georgia by county for 2000 and water-use trends for 1980-2000: Georgia Geologic Survey Information Circular 106, 176 p. 
Fanning, J.L., Doonan, G.A., and Montgomery, L.T., 1992, Water use in Georgia by county for 1990: Georgia Geologic Survey Information Circular 90, 98 p.

Fenneman, N.M., 1938, Physiography of the eastern United States: New York, McGraw-Hill, Inc., 714 p.

Florida Geological Survey, 1986, Hydrogeological units of Florida, compiled by the Southeastern Geological Society Ad Hoc Committee on Florida Hydrostratigraphic Unit Definition: Florida Geological Society Special Publication 28, 9 p.

Gelbaum, Carol, 1978, The geology and groundwater of the Gulf Trough: Georgia Geologic Survey Bulletin 93, p. 38-47.

Gelbaum, Carol, and Howell, Julian, 1982, The geohydrology of the Gulf Trough, in Arden, P.D., Beck, B.F., and Morrow, Elanore, eds., Proceedings of the Second Symposium on the Geology of the Southeastern Coastal Plain: Georgia Geologic Survey Information Circular 53, p. 140-153.

Georgia Department of Environmental Protection, 2008, Georgia Comprehensive State-wide Water Management Plan, accessed on August 19, 2009, at http://www.georgia watercouncil.org/Files_PDF/water_plan_20080109.pdf.

Harrison, K.A., 2001, Agricultural irrigation trends in Georgia, in Hatcher, K.J. ed., Proceedings of the 2001 Georgia Water Resources Conference, March 26-27, 2001, Athens, Georgia, The University of Georgia, Institute of Ecology, p. 114-117.

Harrison, K.A., and Tyson, Anthony, 1999, Agricultural irrigation trends in Georgia, in Hatcher, K.J. ed., Proceedings of the 1999 Georgia Water Resources Conference, March 30-31, 1999, Athens, Georgia, The University of Georgia, Institute of Ecology, p. 421-424.

Hendry, C.W., Jr., and Sproul, D.R., 1966, Geology and groundwater resources of Leon County, Florida: Florida Geological Survey Bulletin 47, 178 p.

Herrick, S.M., 1961, Well logs of the Coastal Plain of Georgia: Georgia Geologic Survey Bulletin 70, 462 p.

Herrick, S.M., and Vorhis, R.C., 1963, Subsurface geology of the Georgia Coastal Plain: Georgia Geological Survey Information Circular 25, $67 \mathrm{p}$.

Hine, A.C., Brooks, G.R., Davis, R.A., Jr., Doyle, L.J., Gelfenbaum, G., Locker, S.D., Twichell, D.C., and Weisberg, R.H., 2001, A summary of findings of the West-Central Florida Coastal Studies Project: U.S. Geological Survey Open-File Report 01-303, 41 p., accessed December 8, 2006, at http://pubs.usgs.gov/of/2001/of01-303/pdf.html.
Huddlestun, P.F., 1988, A revision of the lithostratigraphic units of the Coastal Plain of Georgia: Georgia Geologic Survey Bulletin 104, 162 p.

Jones, L.E., and Torak, L.J., 2004, Simulated effects of impoundment of Lake Seminole on ground-water flow in the Upper Floridan aquifer in southwestern Georgia and adjacent parts of Alabama and Florida: U.S. Geological Survey Scientific Investigations Report 2004-5077, 18 p., accessed September 13, 2005, at http://pubs.usgs. gov/sir/2004/5077/pdf/SIR2004-5077.pdf.

Jones, L.E., and Torak, L.J., 2006, Simulated effects of seasonal ground-water pumpage for irrigation on hydrologic conditions in the lower Apalachicola-Chattahoochee-Flint River Basin, southwestern Georgia and parts of Alabama and Florida, 1999-2002: U.S. Geological Survey Scientific Investigations Report 2006-5234, 106 p.

Jordan, Louise, 1954, Oil possibilities in Florida: Oil and Gas Journal, v. 53, no. 28, p. 370-375.

Katz, B.G., 1992, Hydrochemistry of the Upper Floridan aquifer, Florida: U.S. Geological Survey Water-Resources Investigations Report 91-4196, 37 p.

Katz, B.G., 1998, Using delta 180 and delta D to quantify groundwater/surface-water interactions in karst systems of Florida, in Proceedings of the 1998 National Water Quality Monitoring Conference, July 7-9, Reno, Nevada, 14 p.

Katz, B.G., DeHan, R.S., Hirten, J.J., and Catches, J.S., 1997, Interactions between ground water and surface water in the Suwannee River basin, Florida: Journal of the American Water Resources Association, v. 33, no. 6, p. 1237-1254.

Katz, B.G., Lee, T.M., Plummer, L.N., and Busenberg, Eurybiades, 1995a, Chemical evolution of groundwater near a sinkhole lake, northern Florida; 1, Flow patterns, age of groundwater, and influence of lake water leakage: Water Resources Research, v. 31, no. 6, p. 1549-1564.

Katz, B.G., Plummer, L.N., Busenberg, Eurybiades, Reves, K.M., Jones, B.F., and Lee, T.M., 1995b, Chemical evolution of groundwater near a sinkhole lake, northern Florida; 2, Chemical patterns, mass transfer modeling, and rates of mass transfer reactions: Water Resources Research, v. 31, no. 6 , p. $1565-1584$.

Kellam, M.F., and Gorday, L.L., 1990, Hydrogeology of the Gulf Trough-Apalachicola Embayment area, Georgia: Georgia Geologic Survey Bulletin 94, 74 p.

Krause, R.E., 1979, Geohydrology of Brooks, Lowndes, and western Echols Counties, Georgia: U.S. Geological Survey Water-Resources Investigations 78-117, 48 p. 
Leitman, H.M., Sohm, J.E., and Franklin, M.A., 1984, Wetland hydrology and tree distribution of the Apalachicola River flood plain, Florida: U.S. Geological Survey WaterSupply Paper 2196-A, 52 p.

Leve, G.W., 1968, The Floridan aquifer in northeast Florida: Ground Water, v. 6, no. 2, p. 19-29.

Litts, Thomas, Thomas, Adrian, and Welch, Roy, 2001, Mapping irrigated lands in southwest Georgia: The University of Georgia, Center for Remote Sensing and Mapping Science, Department of Geography, Final Report, Cooperative Agreement No. 649-990205, 56 p.

MacNeil, F.S., 1947, Geologic map of the Tertiary and Quaternary Formations of Georgia: U.S. Geological Survey Oil and Gas Inventory (Preliminary) Map 72, 1 sheet, scale 1:500,000.

Matthews, S.E., Hester, W.G., and O'Byrne, M.P., 1980, Ground-water data for Georgia, 1979: U.S. Geological Survey Open-File Report 80-501, 93 p.

Matthews, S.E., and Krause, R.E., 1984, Hydrogeologic data from the U.S. Geological Survey test wells near Waycross, Ware County, Georgia: U.S. Geological Survey WaterResources Investigations Report 83-4204, 29 p.

McCallie, S.W., 1898, A preliminary on the artesian-well system of Georgia: Georgia Geologic Survey Bulletin 7, 214 p.

McCallie, S.W., 1908, A preliminary report on the underground waters of Georgia: Georgia Geological Survey Bulletin 15, $360 \mathrm{p}$.

McConnell, J.B., and Hacke, C.M., 1993, Hydrogeology, water quality, and water-resources development potential of the Upper Floridan aquifer in the Valdosta area, southcentral Georgia: U.S. Geological Survey Water-Resources Investigations Report 93-4044, 44 p.

McFadden, S.S., Hetrick, J.H., Kellam, M.F., Rodenbeck, S.A., and Huddlestun, P.F., 1986, Geologic data of the Gulf Trough area, Georgia: Georgia Geologic Survey Information Circular 56, 345 p.

Miller, J.A., 1986, Hydrogeologic framework of the Floridan aquifer system in Florida and parts of Georgia, Alabama, and South Carolina: U.S. Geological Survey Professional Paper 1403-B, 91 p.

Miller, J.A., 1988, Geohydrologic data from the Floridan aquifer system in Florida and in parts of Georgia, South Carolina, and Alabama: U.S. Geological Survey Open-File Report 88-86, 678 p., accessed April 30, 2009, at http://pubs.er.usgs.gov/djvu/OFR/1988/ofr_88_86.djvu.

Miller, J.A., 1990, Ground-water atlas of the United States, Section 6, Alabama, Florida, Georgia, and South Carolina: U.S. Geological Survey Hydrologic Atlas HA 730-G, 28 p.
Mineral Gallery, 2008, The mineral monazite, accessed June 27, 2008, at http://www.galleries.com/minerals/ phosphat/monazite/monazite.htm.

Moore, W.E., 1955, Geology of Jackson County, Florida: Florida Geological Survey Bulletin 37, 101 p.

Mosner, M.S., 2002, Stream-aquifer relations and the potentiometric surface of the Upper Floridan aquifer in the lower Apalachicola-Chattahoochee-Flint River Basin in parts of Georgia, Florida, and Alabama, 1999-2000: U.S. Geological Survey Water-Resources Investigations Report 02-4244, 45 p., accessed September 13, 2005, at http://ga.water.usgs. gov/pubs/wrir/wrirO2-4244/.

National Oceanic and Atmospheric Administration, 2002, Climatological data annual summary, 2001: National Oceanic and Atmospheric Administration, v. 105, no. 13, 28 p.

National Oceanic and Atmospheric Administration, 2008, Web Climate Services, accessed February 14, 2008, at http://www.ncdc.noaa.gov/oa/climate/stationlocator.html.

National Oceanic and Atmospheric Administration, 2009, National Climate Data Center, Locate Weather Station, accessed March 26, 2009, at http://www4.ncdc.noaa.gov/ cgi-win/wwcgi.dll? WWDI getstate $U S A$.

Patterson, S.H., and Herrick, S.M., 1971, Chattahoochee anticline, Apalachicola Embayment, Gulf Trough, and related structural features, southwestern Georgia-Fact or fiction: Georgia Geologic Survey Information Circular 41, 16 p.

Payne, D.F., Rumman, M.A., and Clarke, J.S., 2005, Simulation of groundwater flow in coastal Georgia and adjacent parts of South Carolina and Florida-Predevelopment, 1980, and 2000: U.S. Geological Survey Scientific Investigations Report 2005-5089, 91 p., accessed June 2, 2009, at http://pubs.water.usgs.gov/sir2005-5089.

Pierce, R.R., Barber, N.L., and Stiles, H.R., 1984, Georgia irrigation, 1970-80 - A decade of growth: U.S. Geological Survey Water-Resources Investigations Report 83-4177, $29 \mathrm{p}$.

Pittman, J.R., and Berndt, M.P., 2003, Occurrence of herbicide degradation compounds in streams and ground water in agricultural areas of southern Georgia, 2002: in Hatcher, K.J. ed., Proceedings of the 2003 Georgia Water Resources Conference, April 23-24, 2003, Athens, Georgia, The University of Georgia, Institute of Ecology, 4 p., accessed March 6, 2009, at http://ga.water.usgs.gov/pubs/other/ gwrc2003/pdf/Berndt-GWRC2003.pdf.

Planert, Michael, 2007, Simulation of regional ground-water flow in the Suwannee River Basin, northern Florida and southern Georgia: U.S. Geological Survey Scientific Investigations Report 2007-5031, 56 p. 
Plummer, L.N., Busenberg, Eurybiades, Drenkard, Stefan, Schlosser, Peter, Ekwurzel, Brenda, Weppernig, Ralf, McConnell, J.B., and Michel, R.L., 1998a, Flow of river water into a karstic limestone aquifer; 2, Dating the young fraction in groundwater mixtures in the upper Floridan aquifer near Valdosta, Georgia: Applied Geochemistry, v. 13 , no. 8 , p. 1017-1043.

Plummer, L.N., Busenberg, Eurybiades, McConnell, J.B., Drenkard, Stefan, Schlosser, Peter, and Michel, R.L., 1998b, Flow of river water into a karstic limestone aquifer; 1, Tracing the young fraction in groundwater mixtures in the upper Floridan aquifer near Valdosta, Georgia: Applied Geochemistry, v. 13, no. 8, p. 995-1015.

Pratt, T.R., Richards, C.J., Milla, K.A., Wagner, J.R., Johnson, J.L., and Curry, R.J., 1996, Hydrogeology of the Northwest Florida Water Management District: Northwest Florida Water Management District Water Resources Special Report 96-4, 98 p.

Priest, Sherlyn, 2004, Evaluation of ground-water contribution to streamflow in coastal Georgia and parts of Florida and South Carolina: U.S. Geological Survey Scientific Investigations Report 2004-5265, 46 p., accessed June 2, 2009, at http://pubs.usgs.gov/sir/2004/5265/.

Puri, H.S., 1953, Contribution to the study of the Miocene of the Florida Panhandle: Florida Geological Survey Bulletin 36, $345 \mathrm{p}$.

Puri, H.S., and Vernon, R.O., 1964, Summary of the geology of Florida and a guidebook to the classic exposures: Florida Geological Survey Special Publication 5, revised, 312 p.

Raulston, Marvin, Johnson, Cindy, Webster, Kirk, Purdy, Carolyn, and Ceryak, Ron, 1998, Suwannee River Water Management District, in Fernald, E.A., and Purdum, E.D., eds., Water Resources Atlas of Florida: Tallahassee, Florida, Florida State University, Institute of Public Affairs, p. 194-213.

Rupert, F.R., 1990, Geology of Gadsden County, Florida: Florida Geological Survey Bulletin 62, 61 p.

Samet, J.M., and Nero, A.V., 1989, Indoor radon and lung cancer: The New England Journal of Medicine, v. 320, no. 9 , p. 591-594.

Schmidt, Walter, 1984, Neogene stratigraphy and geologic history of the Apalachicola Embayment, Florida: Florida Bureau of Geology Bulletin 57, 96 p.

Schwaner, T.D., and Mount, R.H., 1970, Notes on the distribution, habits, and ecology of the salamander Phaeognathus hubrichti Highton: Copeia, v. 1970, no. 3, p. 571-573.
Scott, T.M., 1986, The lithostratigraphic relationships of the Chattahoochee, St. Marks, and Torreya formations, eastern Florida Panhandle [abs.]: Florida Academy of Sciences, Florida Scientist, v. 49, supplement 1.

Scott, T.M., 1992, A geological overview of Florida: Florida Geological Survey Open-File Report 50, 78 p.

Sever, C.W., 1964, Relation of economic deposits of attapulgite and fuller's earth to geologic structure in southwestern Georgia: U.S. Geological Survey Professional Paper 501-B, p. B116-B118.

Sever, C.W., 1965, Ground-water resources and geology of Seminole, Decatur and Grady Counties, Georgia: U.S. Geological Survey Water-Supply Paper 1809-Q, 30 p.

Sever, C.W., 1966, Reconnaissance of the ground water and geology of Thomas County, Georgia: Georgia Geological Survey Information Circular 34, 14 p.

Sever, C.W., and Herrick, S.M., 1967, Tertiary stratigraphy and geohydrology in southwestern Georgia: U.S. Geological Survey Professional Paper 575-B, p. 50-53.

Sever, C.W., 1972, Ground-water resources and geology of Cook County, Georgia: U.S. Geological Survey Open-file Report (unnumbered), $40 \mathrm{p}$.

Southeast Regional Climate Center, 2008a, Tallahassee WSO AP, Florida (088758), accessed February 19, 2008, at http://www.sercc.com/cgi-bin/sercc/cliMAIN.pl?fl8758.

Southeast Regional Climate Center, 2008b, Lake City 2 E, Florida, (084731), accessed February 19, 2008, at http://www.sercc.com/cgi-bin/sercc/cliMAIN.pl?fl4731.

Southeast Regional Climate Center, 2008c, Cordele, Georgia (092266), accessed February 19, 2008, at http://www.sercc.com/cgi-bin/sercc/cliMAIN.pl?ga2266.

Southeast Regional Climate Center, 2008d, Waycross 4 NE, Georgia (099186), accessed February 19, 2008, at http://www.sercc.com/cgi-bin/sercc/cliMAIN.pl?ga9186.

Southeast Regional Climate Center, 2008e, Ashburn 3 ENE, Georgia (090406), accessed July 9, 2008, at http://www. sercc.com/cgi-bin/sercc/cliMAIN.pl?ga0406.

Southeast Regional Climate Center, 2008f, Cairo 2 N, Georgia (091463), accessed July 9, 2008, at http://www. sercc.com/cgi-bin/sercc/cliMAIN.pl?gal463.

Southeast Regional Climate Center, 2008g, Folkston 9 SW, Georgia (093465), accessed July 9, 2008, at http://www. sercc.com/cgi-bin/sercc/cliMAIN.pl?ga3465.

Southeast Regional Climate Center, 2008h, Homerville, Georgia (094429), accessed July 10, 2008, at http://www. sercc.com/cgi-bin/sercc/cliMAIN.pl?ga4429. 
Southeast Regional Climate Center, 2008i, Moultrie 2 ESE, Georgia (096087), accessed July 9, 2008, at http://www. sercc.com/cgi-bin/sercc/cliMAIN.pl?ga6087.

Southeast Regional Climate Center, 2008j, Quitman 2 NW, Georgia (097276), accessed July 9, 2008, at http://www. sercc.com/cgi-bin/sercc/cliMAIN.pl?ga7276.

Southeast Regional Climate Center, 2008k, Tifton Exp Stn, Georgia (098703), accessed July 9, 2008, at http://www. sercc.com/cgi-bin/sercc/cliMAIN.pl?ga8703.

Sprinkle, C.L., 1989, Geochemistry of the Floridan Aquifer System in Florida and in parts of Georgia, South Carolina, and Alabama: U.S. Geological Survey Professional Paper 1403-I, 105 p.

Stephenson, L.W., and Veatch, J.O., 1915, Underground waters of the Coastal Plain of Georgia and a discussion of the quality of the waters, by R.B. Dole: U.S. Geological Survey Water-Supply Paper 341, 539 p.

Stokes, W.R., III, McFarlane, R.K., and Buell, G.R., 1990, Water resources data, Georgia, water year 1989: U.S. Geological Survey Water Data Report GA-89-1, 513 p.

Thomson, M.T., Herrick, S.M., and Brown, Eugene, 1956, Availability and use of water in Georgia: Georgia Geologic Survey Bulletin 65, 329 p.

Torak, L.J., Crilley, D.M., and Painter, J.A., 2006, Physical and hydrochemical evidence of lake leakage near Jim Woodruff Lock and Dam and assessment of karst features in and near Lake Seminole, southwestern Georgia and northwestern Florida: U.S. Geological Survey Scientific Investigations Report 2005-5084, 90 p.

Torak, L.J., Davis, G.S., Strain, G.A., and Herndon, J.G., 1996, Geohydrology and evaluation of stream-aquifer relations in the Apalachicola-Chattahoochee-Flint River Basin, southeastern Alabama, northwestern Florida, and southwestern Georgia: U.S. Geological Survey WaterSupply Paper 2460, 94 p.

Torak, L.J., and McDowell, R.J., 1996, Ground-water resources of the lower Apalachicola-Chattahoochee-Flint River Basin in parts of Alabama, Florida, and GeorgiaSubarea 4 of the Apalachicola-Chattahoochee-Flint and Alabama-Coosa-Tallapoosa River Basins: U.S. Geological Survey Open-File Report 95-321, 145 p.
Torak, L.J., and Painter, J.A., 2006, Geohydrology of the lower Apalachicola-Chattahoochee-Flint River Basin, southwestern Georgia, northwestern Florida, and southeastern Alabama: U.S. Geological Survey Scientific Investigations Report 2006-5070, 80 p., accessed June 2, 2009, at http://pubs.usgs.gov/sir/2006/5070/.

Turlington, M.C., Fanning, J.L., and Doonan, G.A., 1987, Water use in Georgia by county for 1985: Georgia Geologic Survey Information Circular 81, 109 p.

U.S. Geological Survey, 2006, NAWQA ProgramGeorgia-Florida Coastal Plain Drainages (GAFL) study unit, Georgia-Florida Coastal Plain Publications, accessed on April 2, 2010, at http://fl.water.usgs.gov/NAWQA/.

U.S. Geological Survey, 2008, National Elevation Dataset, accessed on August 6, 2008, at http://ned.usgs.gov/.

Vorhis, R.C., 1972, Geohydrology of Sumter, Dooly, Pulaski, Lee, Crisp, and Wilcox Counties, Georgia: U.S. Geological Survey Hydrologic Atlas HA-435, 2 sheets.

Wait, R.L., 1960, Source and quality of ground water in southwestern Georgia: Georgia Geologic Survey Information Circular 18, 43 p.

Wakulla County Tourist Development Council, 2007, The Rivers of Wakulla, accessed November 16, 2006, at http://www.wakullacounty.org/wakulla-32.htm.

Winston, G.O., 1976, Florida's Ocala Uplift is not an uplift: Bulletin of the American Association of Petroleum Geologists, v. 60, no. 6, p. 992-994.

Yon, J.W., 1966, Geology of Jefferson County, Florida: Florida Bureau of Geology Bulletin 48, 119 p.

Zimmerman, E.A., 1977, Ground-water resources of Colquitt County, Georgia: U.S. Geological Survey OpenFile Report 77-56, 41 p. 
Appendix. Geohydrologic Data 
Table A-1. Geohydrologic data for the Aucilla-Suwannee-Ochlockonee River Basin.

[Accuracy of land-surface altitude varies based on method of measurement. Values reported to hundredths of a foot represent measurement made by surveying or global positioning techniques; - , no data available]

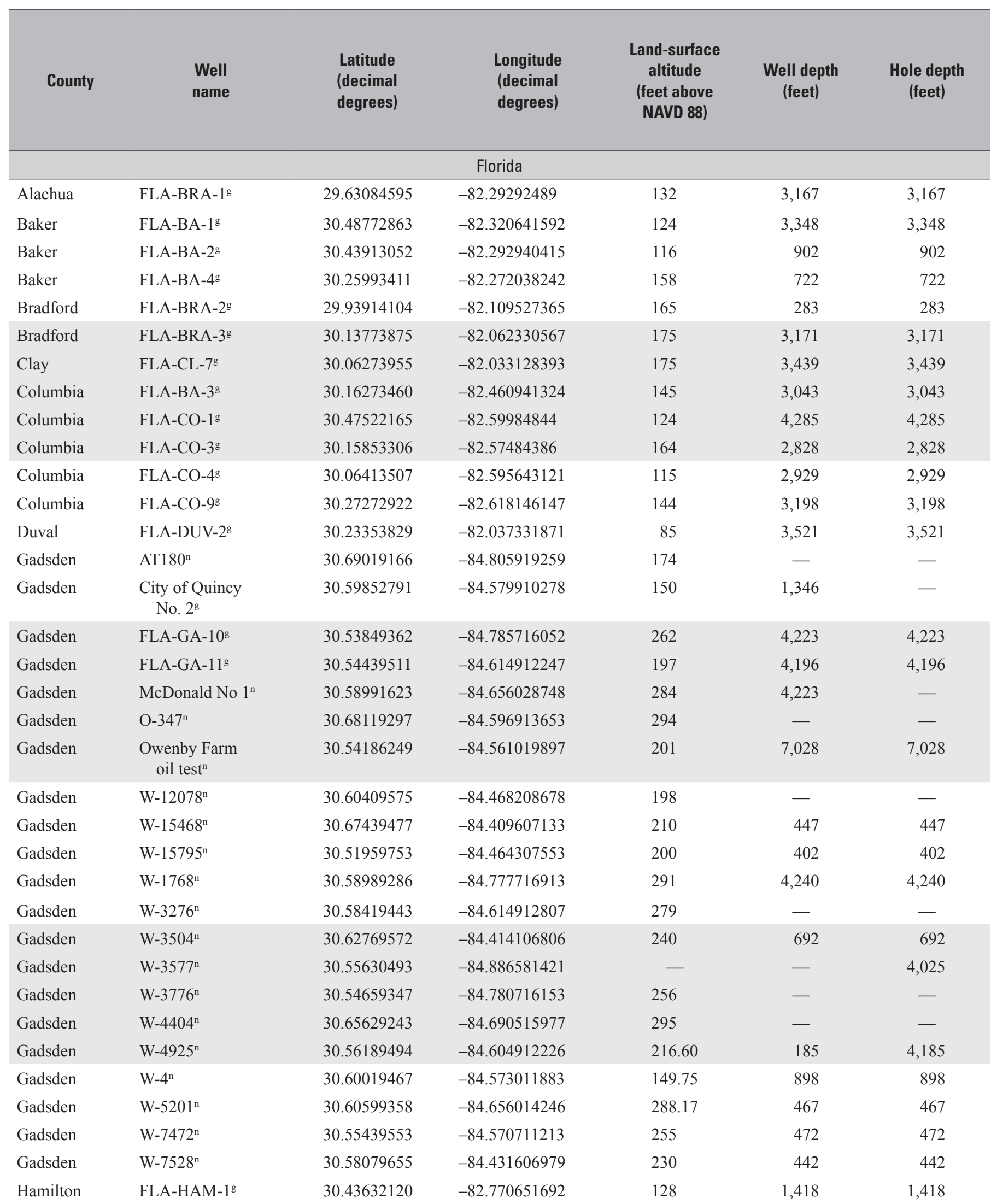


Table A-1. Geohydrologic data for the Aucilla-Suwannee-Ochlockonee River Basin.-Continued

[Accuracy of land-surface altitude varies based on method of measurement. Values reported to hundredths of a foot represent measurement made by surveying or global positioning techniques; - , no data available]

\begin{tabular}{|c|c|c|c|c|c|c|c|c|}
\hline $\begin{array}{l}\text { Well } \\
\text { name }\end{array}$ & $\begin{array}{c}\text { Top } \\
\text { altitude, } \\
\text { Upper } \\
\text { Floridan } \\
\text { aquifer }\end{array}$ & $\begin{array}{l}\text { Bottom } \\
\text { altitude, } \\
\text { Upper } \\
\text { Floridan } \\
\text { aquifer }\end{array}$ & $\begin{array}{c}\text { Top } \\
\text { altitude, } \\
\text { Tampa } \\
\text { Limestone }\end{array}$ & $\begin{array}{c}\text { Top } \\
\text { altitude, } \\
\text { Suwannee } \\
\text { Limestone }\end{array}$ & $\begin{array}{c}\text { Top } \\
\text { altitude, } \\
\text { Ocala } \\
\text { Limestone }\end{array}$ & $\begin{array}{c}\text { Top } \\
\text { altitude, } \\
\text { Lisbon or } \\
\text { Avon Park } \\
\text { Formation }\end{array}$ & $\begin{array}{c}\text { Top } \\
\text { altitude, } \\
\text { Tallahatta } \\
\text { Formation }\end{array}$ & $\begin{array}{c}\text { Top } \\
\text { altitude, } \\
\text { Wilcox } \\
\text { Group }\end{array}$ \\
\hline & \multicolumn{8}{|c|}{ Feet above or below NAVD 88} \\
\hline \multicolumn{9}{|c|}{ Florida } \\
\hline FLA-BRA-1 ${ }^{g}$ & -63 & -938 & - & - & - & - & - & - \\
\hline FLA-BA-1 ${ }^{\mathrm{g}}$ & -196 & $-1,089$ & - & - & - & - & - & - \\
\hline FLA-BA- $2^{g}$ & -272 & - & - & - & - & - & - & - \\
\hline FLA-BA-4 $4^{\mathrm{g}}$ & -150 & - & - & - & - & - & - & - \\
\hline FLA-BRA-2 ${ }^{\mathrm{g}}$ & -101 & - & - & - & - & - & - & - \\
\hline FLA-BRA-3 & -189 & -533 & - & - & - & - & - & - \\
\hline FLA-CL-7g & -226 & -642 & - & - & - & - & - & - \\
\hline FLA-BA-3 & -68 & -884 & - & - & - & - & - & - \\
\hline FLA-CO- $1^{g}$ & -57 & -467 & - & - & - & - & - & - \\
\hline FLA-CO-3 ${ }^{\mathrm{g}}$ & - & -838 & - & - & - & - & - & - \\
\hline FLA-CO-4 $4^{\mathrm{g}}$ & 35 & -885 & - & - & - & - & - & - \\
\hline FLA-CO-9g & -22 & -828 & - & - & - & - & - & - \\
\hline FLA-DUV-2 ${ }^{g}$ & - & -764 & - & - & - & - & - & - \\
\hline AT180 & 60 & -634 & - & - & - & - & - & - \\
\hline $\begin{array}{l}\text { City of Quincy } \\
\text { No. } 2^{\mathrm{g}}\end{array}$ & -185 & - & - & - & - & - & - & - \\
\hline FLA-GA-10 & 142 & -830 & - & - & - & - & - & - \\
\hline FLA-GA-11 & - & -988 & - & - & - & - & - & - \\
\hline McDonald No $1^{\mathrm{n}}$ & -286 & -696 & - & - & - & - & - & - \\
\hline $\mathrm{O}-347^{\mathrm{n}}$ & -100 & -600 & - & - & - & - & - & - \\
\hline $\begin{array}{l}\text { Owenby Farm } \\
\text { oil test }^{\mathrm{n}}\end{array}$ & -279 & - & - & - & - & - & - & - \\
\hline $\mathrm{W}-12078^{\mathrm{n}}$ & -219 & - & - & - & - & - & - & - \\
\hline W-15468 & -205 & - & - & - & - & - & - & - \\
\hline $\mathrm{W}-15795^{\mathrm{n}}$ & -160 & - & - & - & - & - & - & - \\
\hline W-1768 & -80 & - & - & - & - & - & - & - \\
\hline $\mathrm{W}-3276^{\mathrm{n}}$ & -258 & - & - & - & - & - & - & - \\
\hline $\mathrm{W}-3504^{\mathrm{n}}$ & -266 & - & - & - & - & - & - & - \\
\hline $\mathrm{W}-3577^{\mathrm{n}}$ & -135 & -845 & - & - & - & - & - & - \\
\hline $\mathrm{W}-3776^{\mathrm{n}}$ & -208 & - & - & - & - & - & - & - \\
\hline $\mathrm{W}-4404^{\mathrm{n}}$ & -77 & - & - & - & - & - & - & - \\
\hline $\mathrm{W}-4925^{\mathrm{n}}$ & -303 & - & - & - & - & - & - & - \\
\hline $\mathrm{W}-4^{\mathrm{n}}$ & -230 & -880 & - & - & - & - & - & - \\
\hline $\mathrm{W}-5201^{\mathrm{n}}$ & -179 & - & - & - & - & - & - & - \\
\hline $\mathrm{W}-7472^{\mathrm{n}}$ & -180 & - & - & - & - & - & - & - \\
\hline W-7528 & -179 & - & - & - & - & - & - & - \\
\hline FLA-HAM-1 ${ }^{\mathrm{g}}$ & 10 & -878 & - & - & - & - & - & - \\
\hline
\end{tabular}


Table A-1. Geohydrologic data for the Aucilla-Suwannee-Ochlockonee River Basin.-Continued

[Accuracy of land-surface altitude varies based on method of measurement. Values reported to hundredths of a foot represent measurement made by surveying or global positioning techniques; - , no data available]

\begin{tabular}{|c|c|c|c|c|c|c|}
\hline County & $\begin{array}{l}\text { Well } \\
\text { name }\end{array}$ & $\begin{array}{l}\text { Latitude } \\
\text { (decimal } \\
\text { degrees) }\end{array}$ & $\begin{array}{l}\text { Longitude } \\
\text { (decimal } \\
\text { degrees) }\end{array}$ & $\begin{array}{l}\text { Land-surface } \\
\text { altitude } \\
\text { (feet above } \\
\text { NAVD 88) }\end{array}$ & $\begin{array}{l}\text { Well depth } \\
\text { (feet) }\end{array}$ & $\begin{array}{l}\text { Hole depth } \\
\text { (feet) }\end{array}$ \\
\hline \multicolumn{7}{|c|}{ Florida } \\
\hline Leon & FLA-LN-1 ${ }^{\mathrm{g}}$ & 30.31190320 & -84.116591778 & 30 & 6,520 & 6,520 \\
\hline Leon & FLA-LN-2g & 30.31190240 & -84.194894845 & 17 & 10,466 & 10,466 \\
\hline Leon & FLA-LN-4 ${ }^{\mathrm{g}}$ & 30.38739714 & -84.645710696 & 41 & 525 & 525 \\
\hline Leon & Hopkins Plant \#3g & 30.45519829 & -84.397956848 & 138 & 406 & 425 \\
\hline Leon & $\mathrm{W}-6902^{\mathrm{n}}$ & 30.51829888 & -84.324302177 & 80 & 158 & 158 \\
\hline Leon & W-6937n & 30.59269903 & -84.05459255 & 245 & 248 & 248 \\
\hline Leon & W-6998 & 30.58849858 & -84.151296202 & 237 & 227 & 227 \\
\hline Leon & $\mathrm{W}-7181^{\mathrm{n}}$ & 30.58459822 & -84.227999085 & 249 & 262 & 262 \\
\hline Liberty & AT095 & 30.29119736 & -84.982915394 & 52 & - & - \\
\hline Liberty & $0-83^{n}$ & 30.37819684 & -84.68691154 & 89 & - & - \\
\hline Liberty & $O-93^{n}$ & 30.42219591 & -84.874915112 & 173 & - & 一 \\
\hline Liberty & $\mathrm{W}-15497^{\mathrm{n}}$ & 30.59579365 & -84.901618615 & 245 & 302 & 302 \\
\hline Madison & FLA-MAD- $1^{\mathrm{g}}$ & 30.40021588 & -83.236563825 & 86 & 3,333 & 3,333 \\
\hline Madison & FLA-MAD-2 ${ }^{g}$ & 30.43021249 & -83.358167708 & 102 & 5,385 & 5,385 \\
\hline Madison & FLA-MAD-3 $3^{g}$ & 30.30691821 & -83.260663294 & 84 & 3,450 & 3,450 \\
\hline Suwannee & FLA-LAF-1 ${ }^{\mathrm{g}}$ & 30.14462146 & -83.230460443 & 43 & 4,235 & 4,235 \\
\hline Suwannee & FLA-SUW-4 ${ }^{g}$ & 30.28632600 & -82.822050206 & 152 & 3,572 & 3,572 \\
\hline Suwannee & FLA-SUW-6 ${ }^{\mathrm{g}}$ & 30.20022274 & -83.133157457 & 85 & 3,819 & 3,819 \\
\hline Suwannee & FLA-SUW-7" & 30.07382990 & -82.826248372 & 86 & 3,139 & 3,139 \\
\hline Taylor & FLA-TAY-4" & 29.95521819 & -83.439864512 & 57 & 4,877 & 4,877 \\
\hline Taylor & FLA-TAY-7g & 30.02801141 & -83.812377031 & 126 & 3,036 & 7,502 \\
\hline Union & FLA-UN-2 ${ }^{\mathrm{g}}$ & 30.04193712 & -82.531541396 & 126 & 3,036 & 3,036 \\
\hline Wakulla & FLA-WAK-1 ${ }^{\mathrm{g}}$ & 30.22520347 & -84.19989402 & 28 & 5,766 & 5,766 \\
\hline Wakulla & FLA-WAK-2 & 30.27379969 & -84.533206441 & 85 & 11,735 & 11,735 \\
\hline Wakulla & $\mathrm{O}-75^{\mathrm{n}}$ & 30.30019819 & -84.682910219 & 75 & - & 一 \\
\hline
\end{tabular}


Table A-1. Geohydrologic data for the Aucilla-Suwannee-0chlockonee River Basin.-Continued

[Accuracy of land-surface altitude varies based on method of measurement. Values reported to hundredths of a foot represent measurement made by surveying or global positioning techniques; - , no data available]

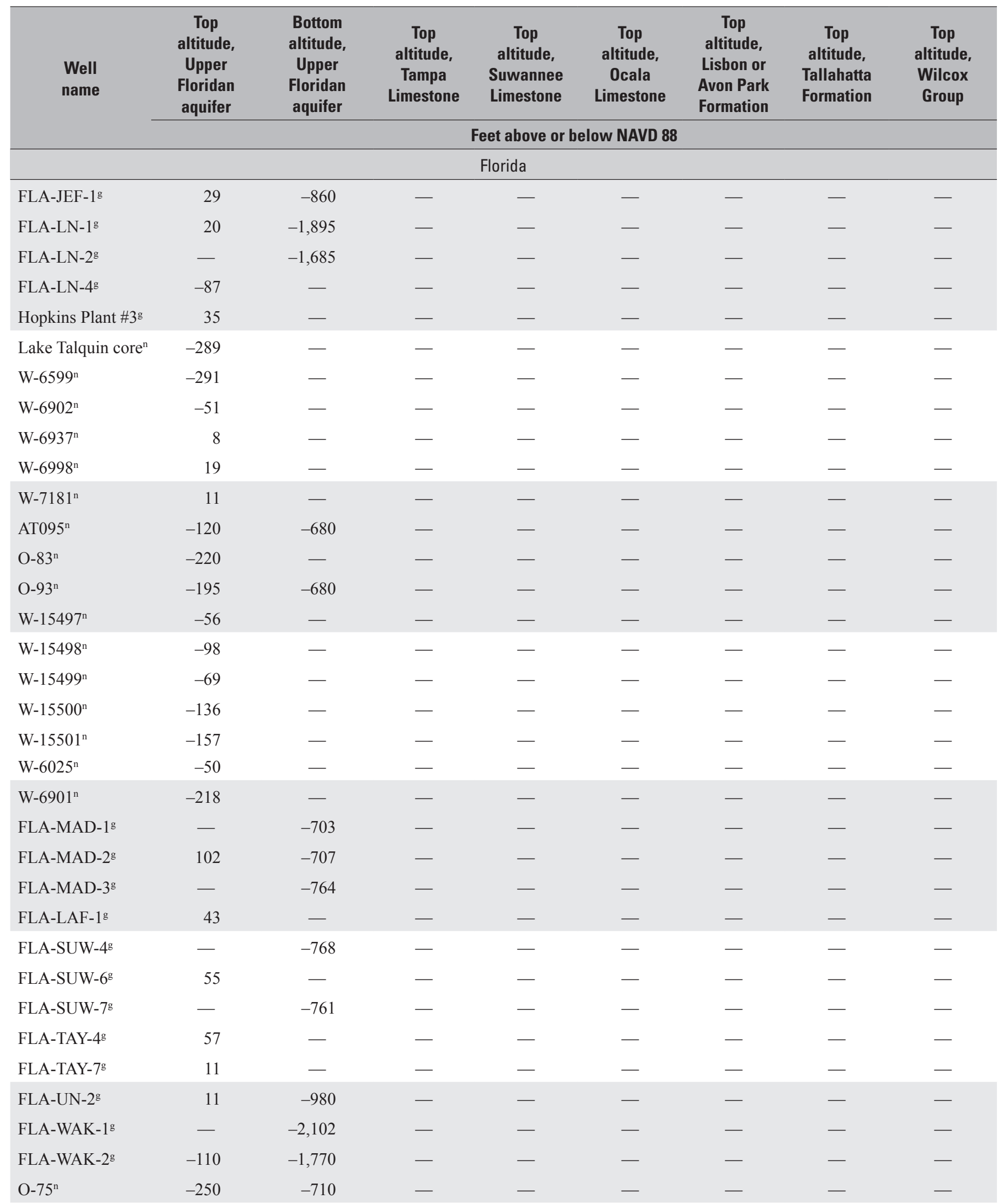


Table A-1. Geohydrologic data for the Aucilla-Suwannee-Ochlockonee River Basin.-Continued

[Accuracy of land-surface altitude varies based on method of measurement. Values reported to hundredths of a foot represent measurement made by surveying or global positioning techniques; - , no data available]

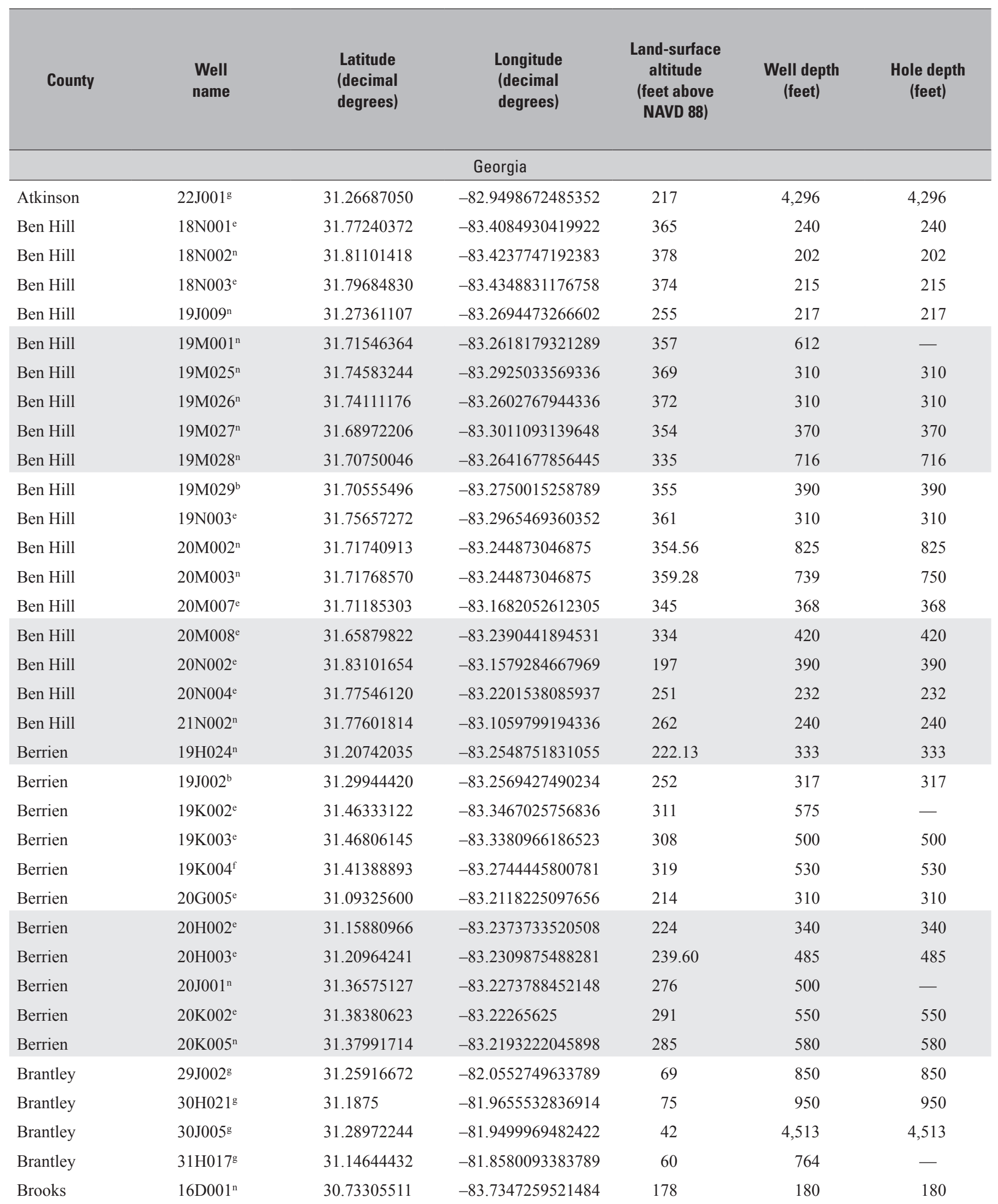


Table A-1. Geohydrologic data for the Aucilla-Suwannee-0chlockonee River Basin.-Continued

[Accuracy of land-surface altitude varies based on method of measurement. Values reported to hundredths of a foot represent measurement made by surveying or global positioning techniques; - , no data available]

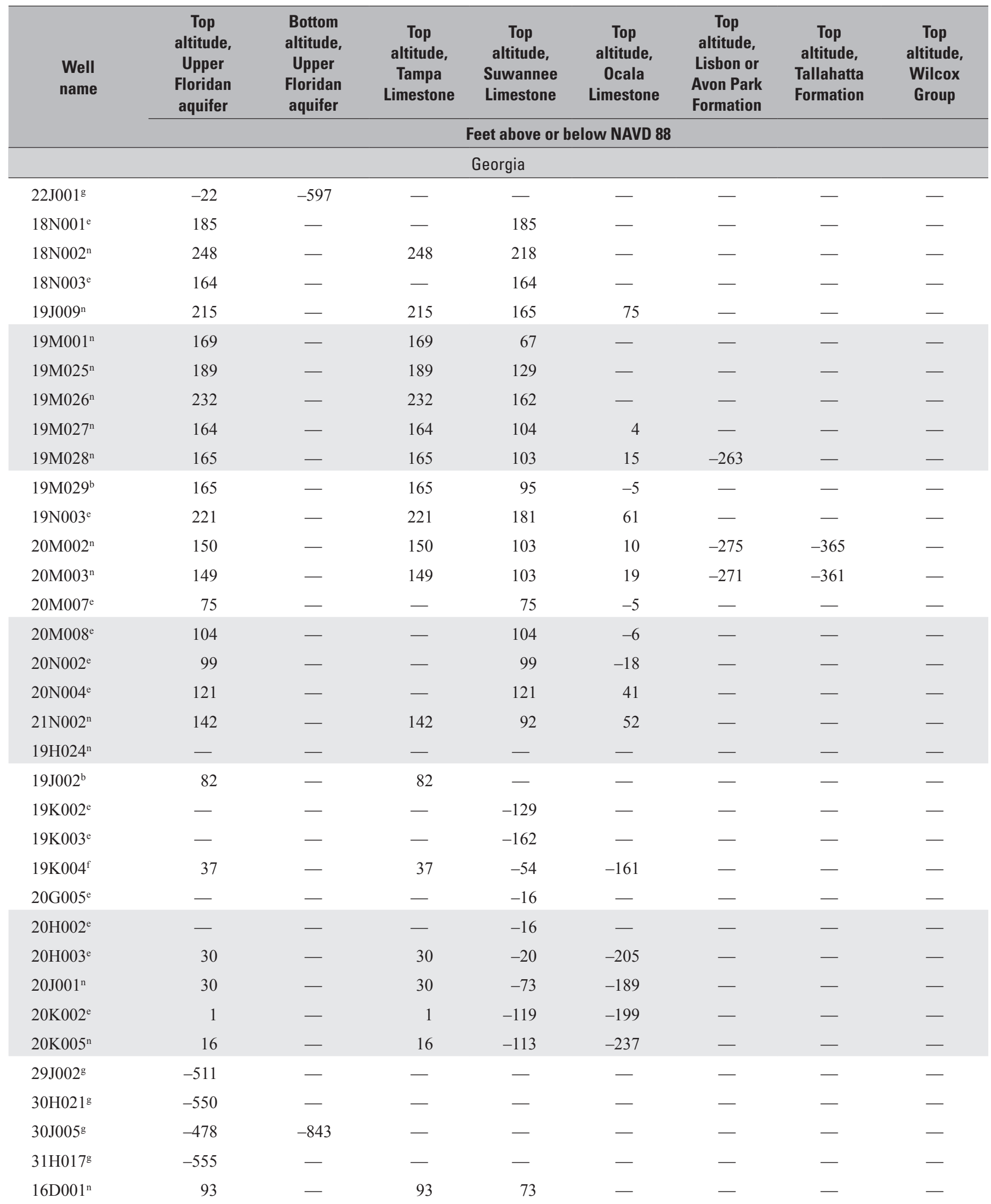


Table A-1. Geohydrologic data for the Aucilla-Suwannee-Ochlockonee River Basin.—Continued

[Accuracy of land-surface altitude varies based on method of measurement. Values reported to hundredths of a foot represent measurement made by surveying or global positioning techniques; - , no data available]

\begin{tabular}{|c|c|c|c|c|c|c|}
\hline County & $\begin{array}{l}\text { Well } \\
\text { name }\end{array}$ & $\begin{array}{l}\text { Latitude } \\
\text { (decimal } \\
\text { degrees) }\end{array}$ & $\begin{array}{l}\text { Longitude } \\
\text { (decimal } \\
\text { degrees) }\end{array}$ & $\begin{array}{l}\text { Land-surface } \\
\text { altitude } \\
\text { (feet above } \\
\text { NAVD 88) }\end{array}$ & $\begin{array}{l}\text { Well depth } \\
\text { (feet) }\end{array}$ & $\begin{array}{l}\text { Hole depth } \\
\text { (feet) }\end{array}$ \\
\hline \multicolumn{7}{|c|}{ Georgia } \\
\hline Brooks & $16 \mathrm{D} 004^{\mathrm{n}}$ & 30.66416740 & -83.6369476318359 & 105 & 147 & 147 \\
\hline Brooks & $16 \mathrm{D} 006^{\mathrm{e}}$ & 30.74214172 & -83.6626586914062 & 196 & 220 & 220 \\
\hline Brooks & $16 \mathrm{D} 007^{\mathrm{n}}$ & 30.68527794 & -83.6577758789062 & 135 & 196 & 196 \\
\hline Brooks & $16 \mathrm{D} 010^{\mathrm{n}}$ & 30.67936516 & -83.6868286132812 & 170 & 180 & 292 \\
\hline Brooks & $16 \mathrm{E} 006^{\mathrm{e}}$ & 30.75805473 & -83.6719436645508 & 193 & 225 & 225 \\
\hline Brooks & $16 \mathrm{~F} 003^{\mathrm{n}}$ & 30.99629974 & -83.7201690673828 & 245 & 265 & 265 \\
\hline Brooks & $16 \mathrm{~F} 006^{\mathrm{e}}$ & 30.88388824 & -83.7074966430664 & 228 & 240 & 240 \\
\hline Brooks & $16 \mathrm{~F} 009^{\mathrm{e}}$ & 30.88074875 & -83.6362762451172 & 230 & 230 & 230 \\
\hline Brooks & $16 \mathrm{~F} 016^{\mathrm{e}, \mathrm{f}}$ & 30.94055557 & -83.7350006103516 & 220 & 748 & 748 \\
\hline Brooks & $16 \mathrm{~F} 017^{\mathrm{g}}$ & 30.94056129 & -83.7350006103516 & 200 & 335 & 335 \\
\hline Brooks & $16 \mathrm{G} 009^{\mathrm{e}}$ & 31.01768875 & -83.7229461669922 & 251.83 & 300 & 300 \\
\hline Brooks & $16 \mathrm{G} 042^{\mathrm{e}, \mathrm{f}}$ & 31.01638794 & -83.7311019897461 & 260 & 856 & 856 \\
\hline Brooks & $17 \mathrm{E} 008^{\mathrm{e}}$ & 30.80277824 & -83.5580520629883 & 142 & 200 & 200 \\
\hline Brooks & $17 \mathrm{E} 009^{\mathrm{e}}$ & 30.86833382 & -83.5250015258789 & 212 & 218 & 218 \\
\hline Brooks & $17 \mathrm{E} 012^{\mathrm{n}}$ & 30.78380775 & -83.5640487670898 & 183 & 304 & 304 \\
\hline Brooks & $17 \mathrm{E} 027^{\mathrm{e}}$ & 30.79972267 & -83.6005554199219 & 165 & 200 & 200 \\
\hline Brooks & $17 \mathrm{~F} 007^{\mathrm{e}}$ & 30.91685867 & -83.5798873901367 & 202 & 186 & 186 \\
\hline Brooks & $17 \mathrm{~F} 008^{\mathrm{e}}$ & 30.89833260 & -83.5272216796875 & 238 & 250 & 250 \\
\hline Brooks & $17 \mathrm{~F} 009^{\mathrm{n}}$ & 30.95574570 & -83.6110000610352 & 200 & 3,850 & 3,850 \\
\hline Brooks & $17 \mathrm{~F} 013^{\mathrm{n}}$ & 30.98638916 & -83.6144409179687 & 161 & 821 & 821 \\
\hline Brooks & $17 \mathrm{G} 003^{\mathrm{n}}$ & 31.00769043 & -83.5143280029297 & 257 & 228 & - \\
\hline Brooks & $18 \mathrm{D} 001^{\mathrm{e}}$ & 30.66222191 & -83.495002746582 & 163 & 200 & 200 \\
\hline Brooks & $18 \mathrm{D} 002^{\mathrm{n}}$ & 30.69305611 & -83.4769439697266 & 194 & 310 & 310 \\
\hline Brooks & $18 \mathrm{E} 001^{\mathrm{e}}$ & 30.81908607 & -83.4893264770508 & 244 & 205 & 205 \\
\hline Brooks & $18 \mathrm{E} 002^{\mathrm{n}}$ & 30.80305481 & -83.4738922119141 & 180 & 156 & 156 \\
\hline Brooks & $18 \mathrm{E} 014^{\mathrm{n}}$ & 30.86936378 & -83.3945999145508 & 173 & 180 & 180 \\
\hline
\end{tabular}


Table A-1. Geohydrologic data for the Aucilla-Suwannee-Ochlockonee River Basin.-Continued

[Accuracy of land-surface altitude varies based on method of measurement. Values reported to hundredths of a foot represent measurement made by surveying or global positioning techniques; - , no data available]

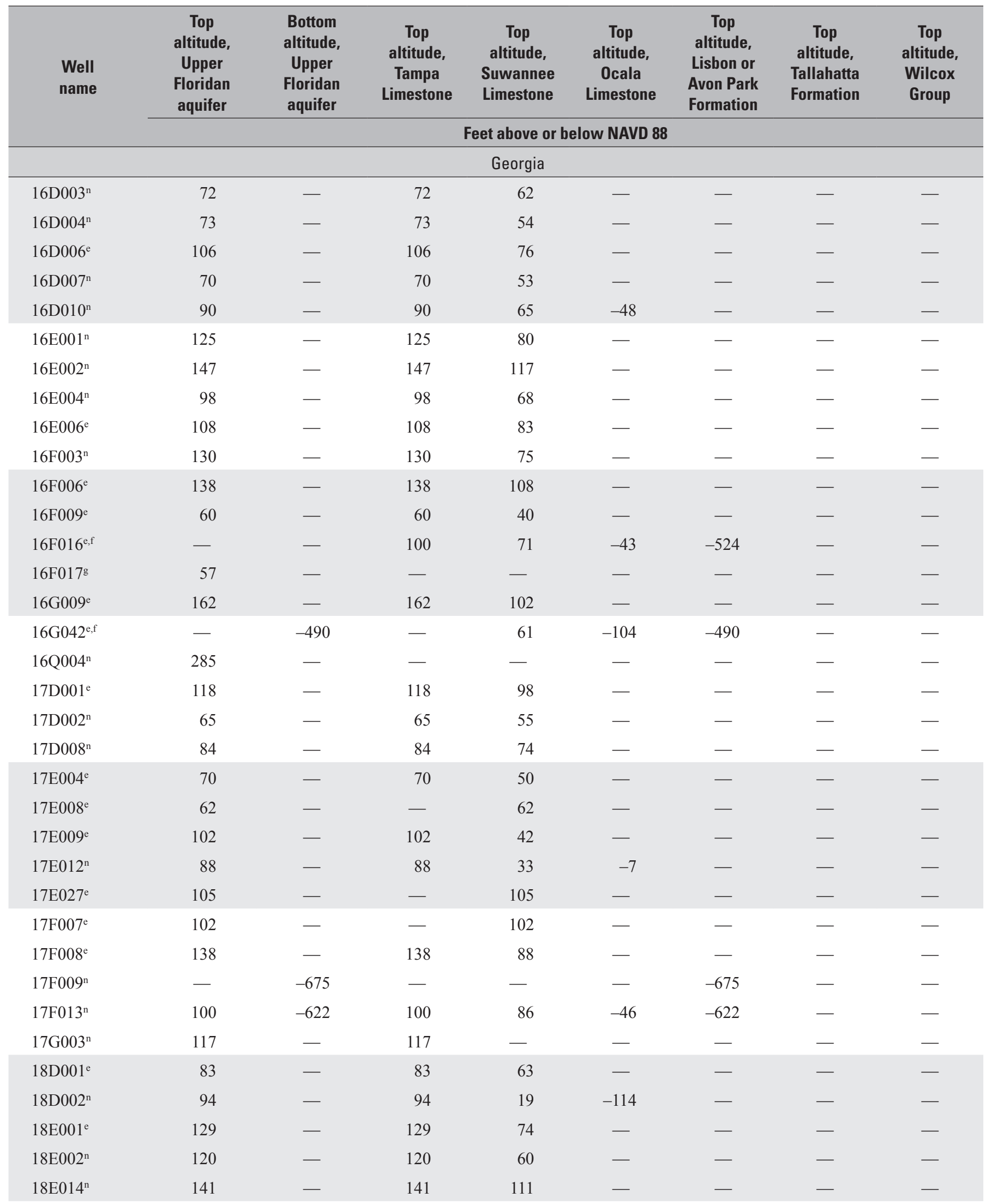


Table A-1. Geohydrologic data for the Aucilla-Suwannee-Ochlockonee River Basin.—Continued

[Accuracy of land-surface altitude varies based on method of measurement. Values reported to hundredths of a foot represent measurement made by surveying or global positioning techniques; - , no data available]

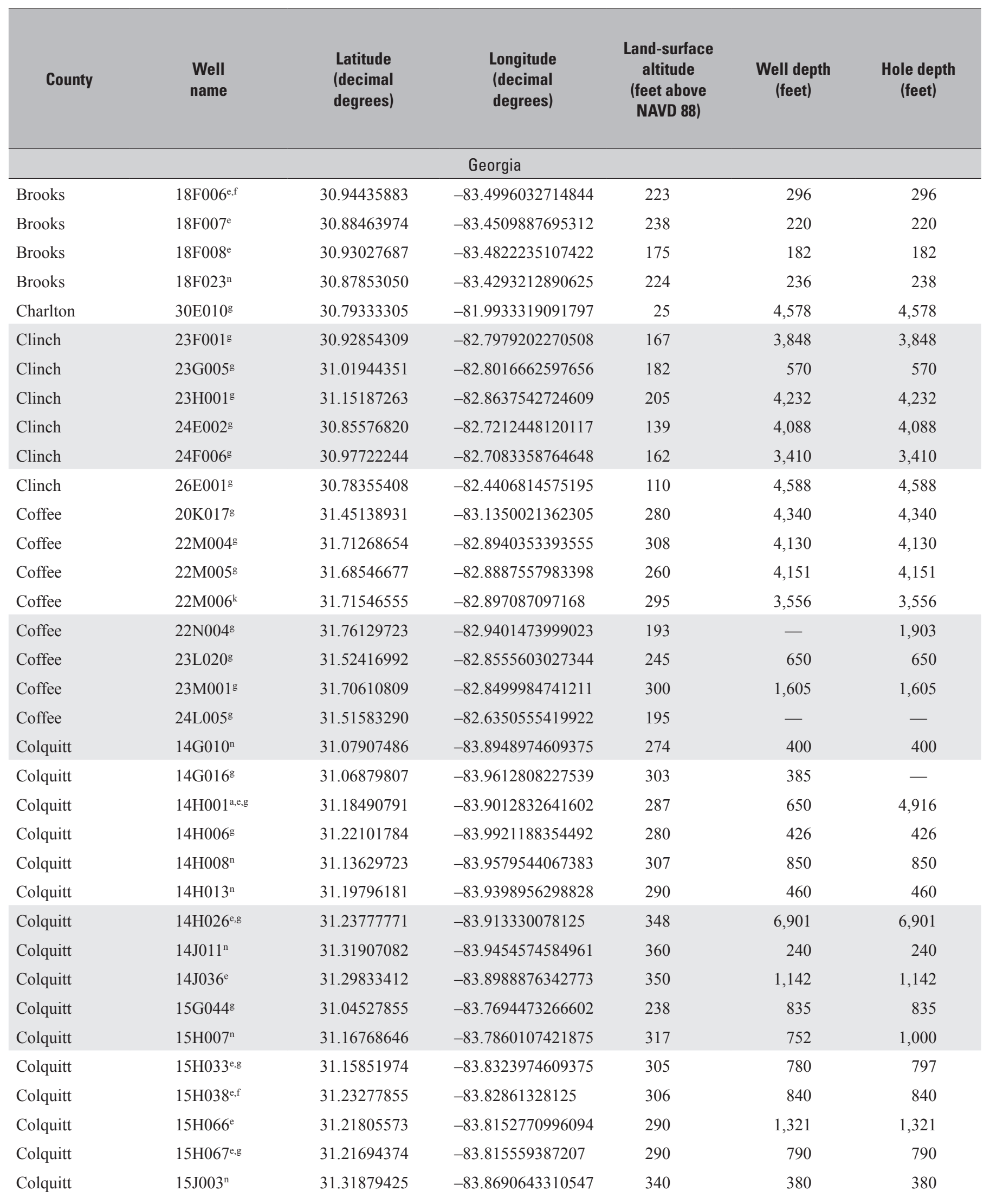


Table A-1. Geohydrologic data for the Aucilla-Suwannee-Ochlockonee River Basin.-Continued

[Accuracy of land-surface altitude varies based on method of measurement. Values reported to hundredths of a foot represent measurement made by surveying or global positioning techniques; - , no data available]

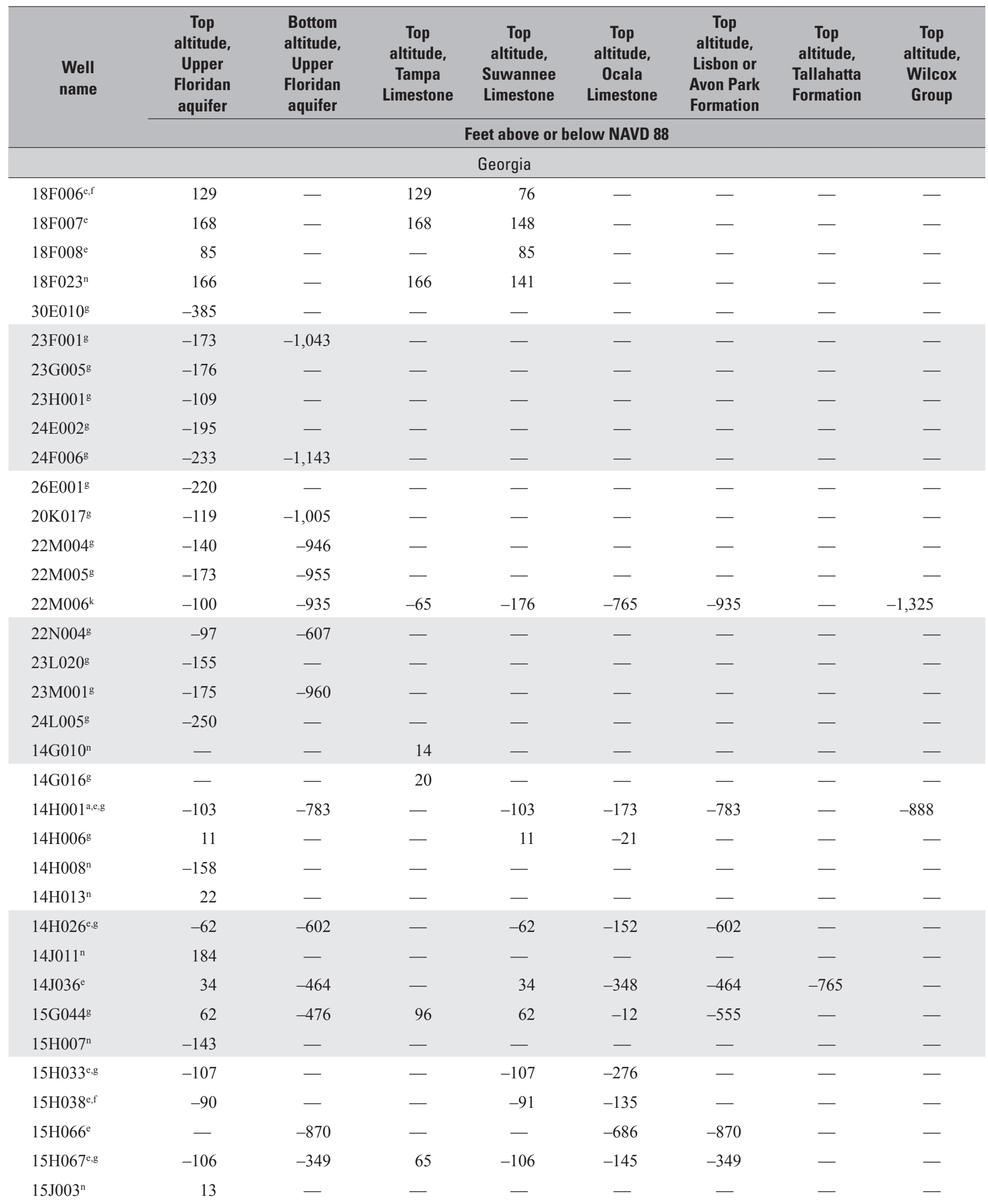


Table A-1. Geohydrologic data for the Aucilla-Suwannee-Ochlockonee River Basin.-Continued

[Accuracy of land-surface altitude varies based on method of measurement. Values reported to hundredths of a foot represent measurement made by surveying or global positioning techniques; - , no data available]

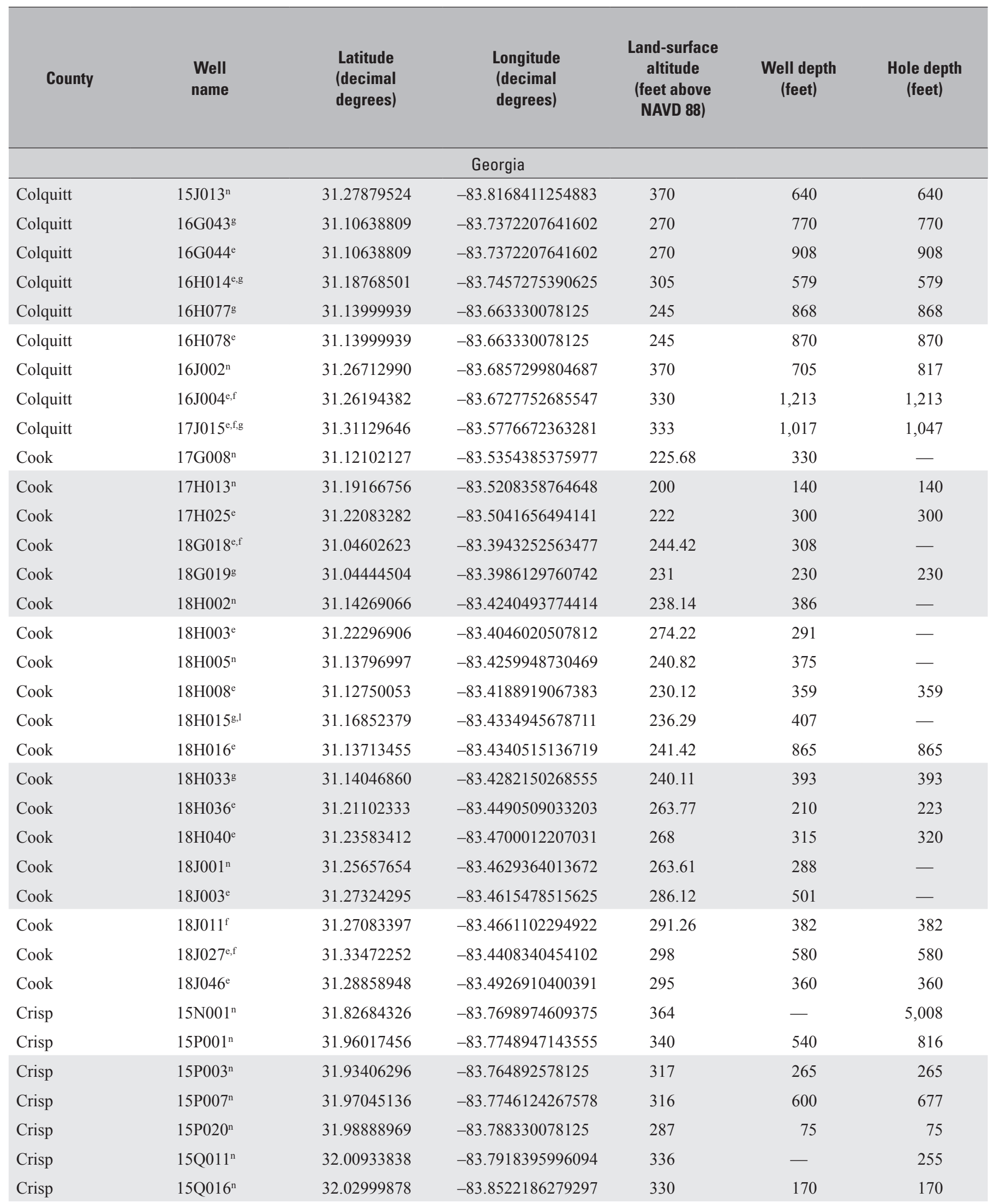


Table A-1. Geohydrologic data for the Aucilla-Suwannee-Ochlockonee River Basin.-Continued

[Accuracy of land-surface altitude varies based on method of measurement. Values reported to hundredths of a foot represent measurement made by surveying or global positioning techniques; - , no data available]

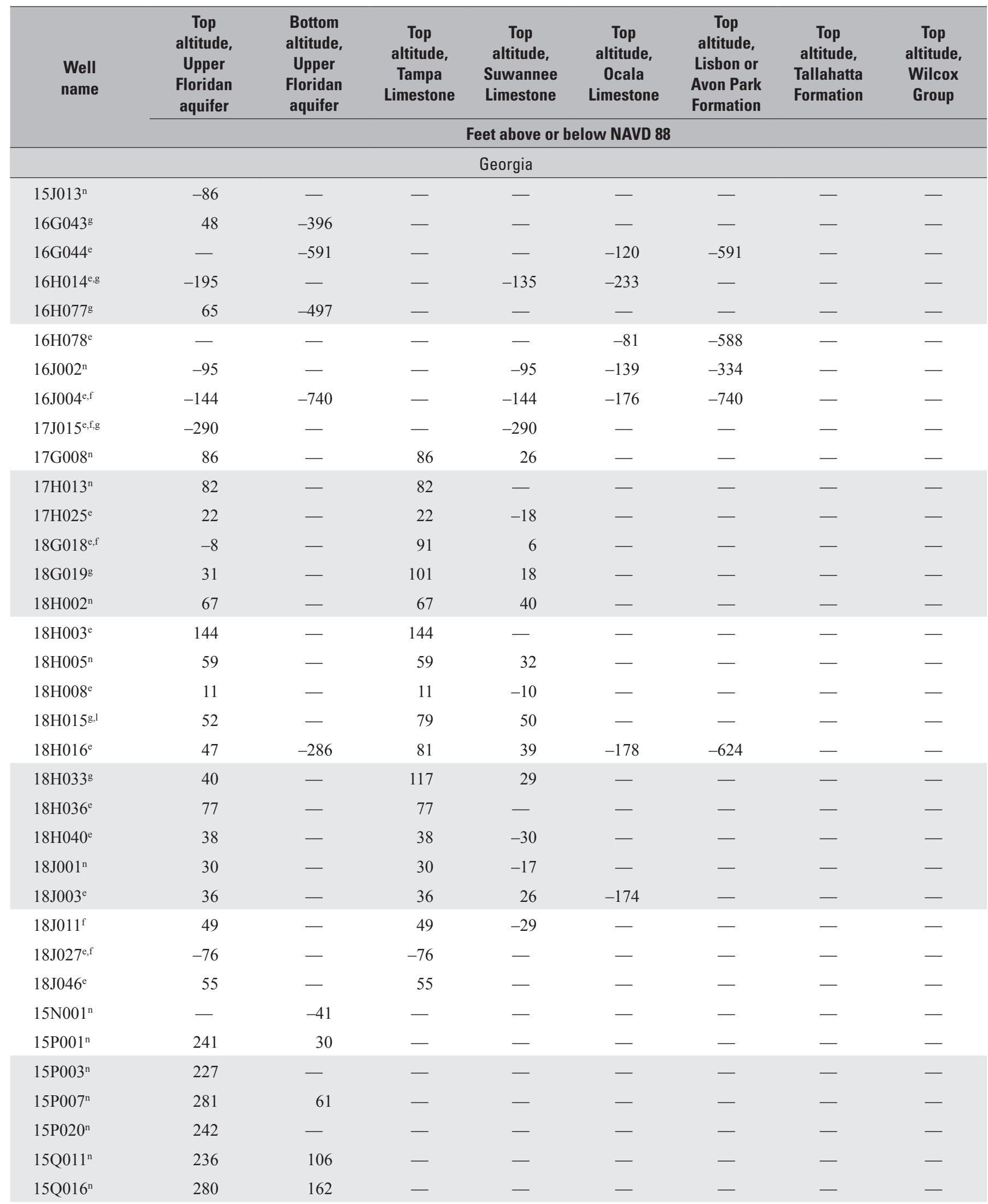


Table A-1. Geohydrologic data for the Aucilla-Suwannee-Ochlockonee River Basin.—Continued

[Accuracy of land-surface altitude varies based on method of measurement. Values reported to hundredths of a foot represent measurement made by surveying or global positioning techniques; - , no data available]

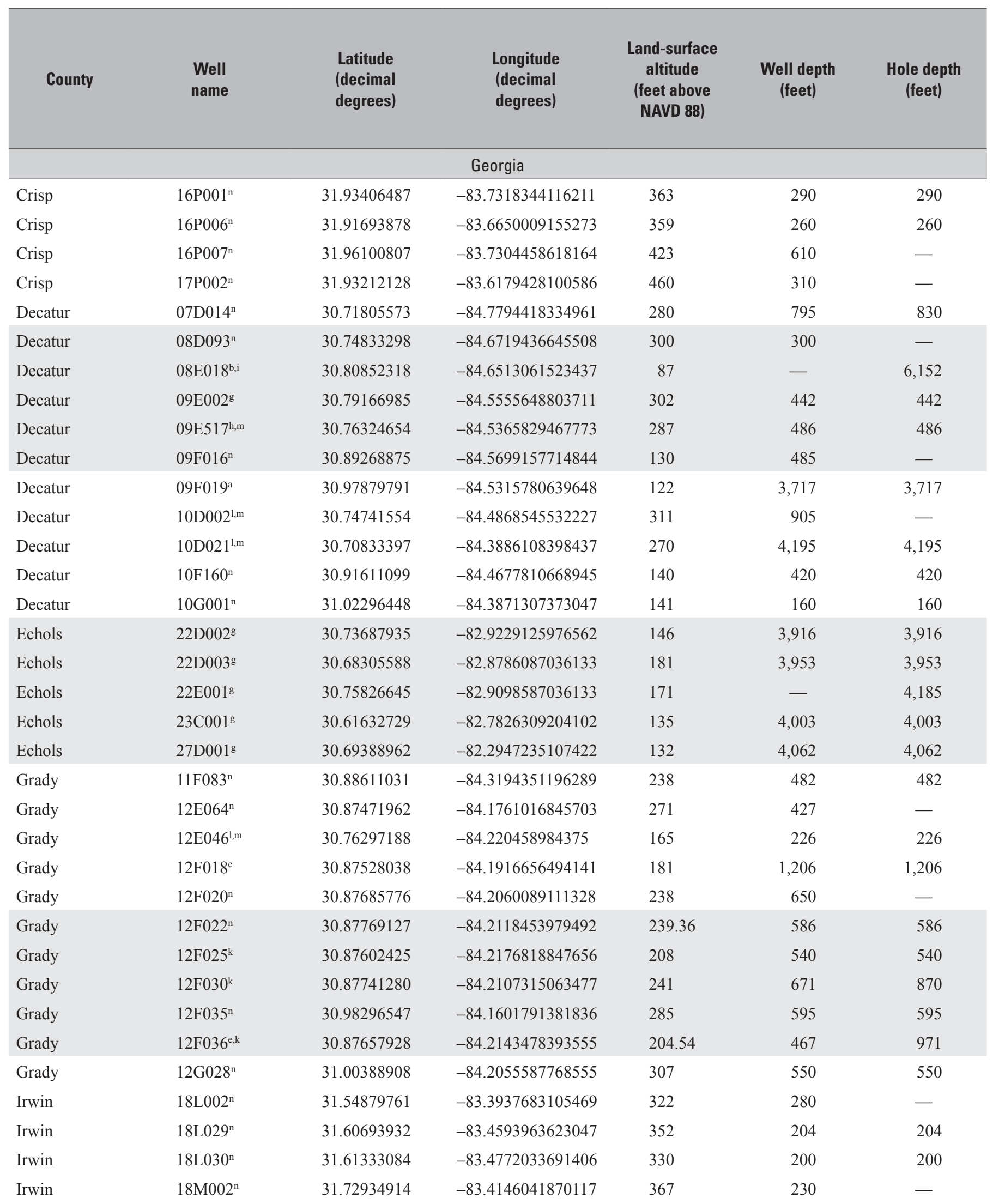


Table A-1. Geohydrologic data for the Aucilla-Suwannee-Ochlockonee River Basin.-Continued

[Accuracy of land-surface altitude varies based on method of measurement. Values reported to hundredths of a foot represent measurement made by surveying or global positioning techniques; - , no data available]

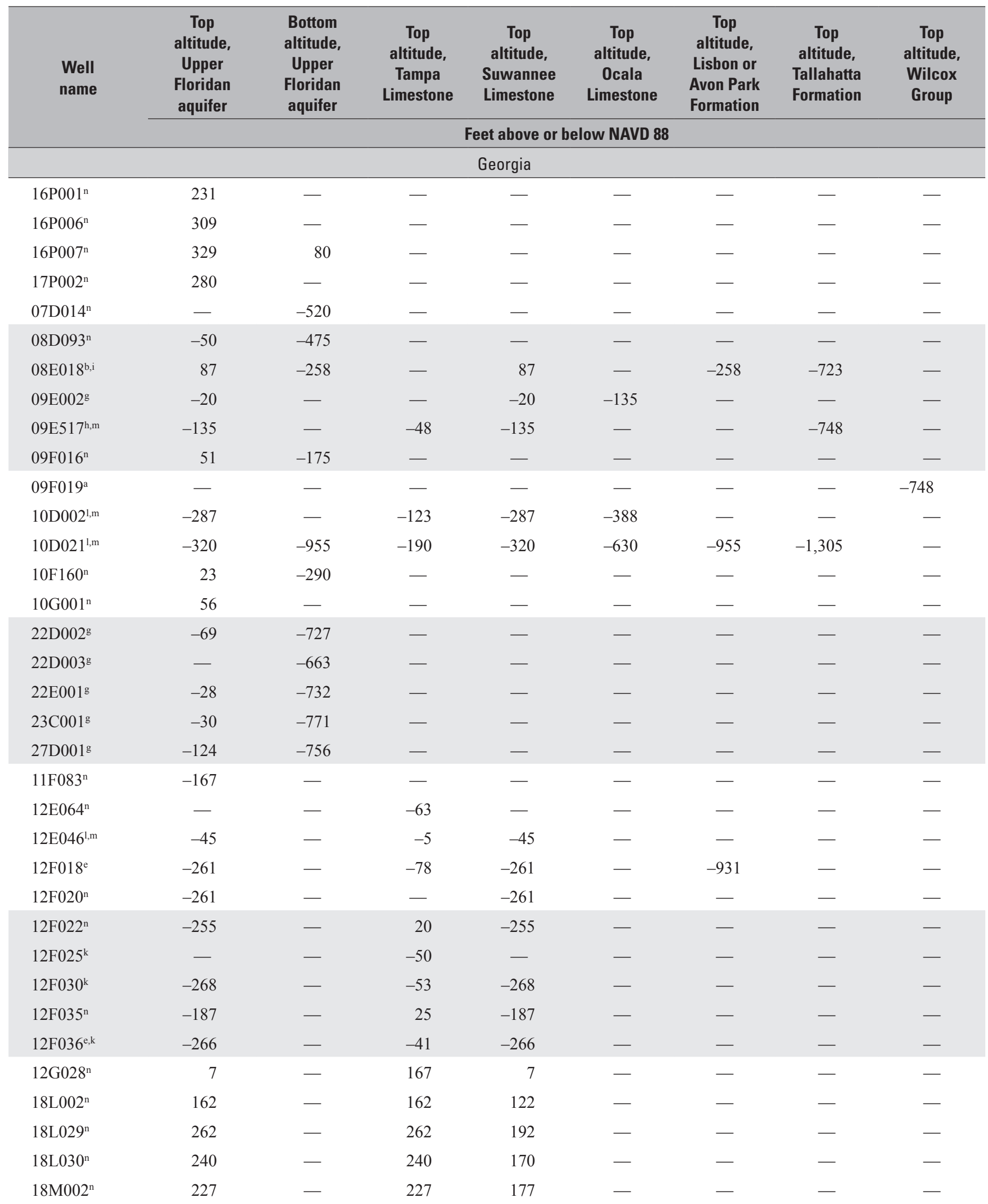


Table A-1. Geohydrologic data for the Aucilla-Suwannee-Ochlockonee River Basin.—Continued

[Accuracy of land-surface altitude varies based on method of measurement. Values reported to hundredths of a foot represent measurement made by surveying or global positioning techniques; - , no data available]

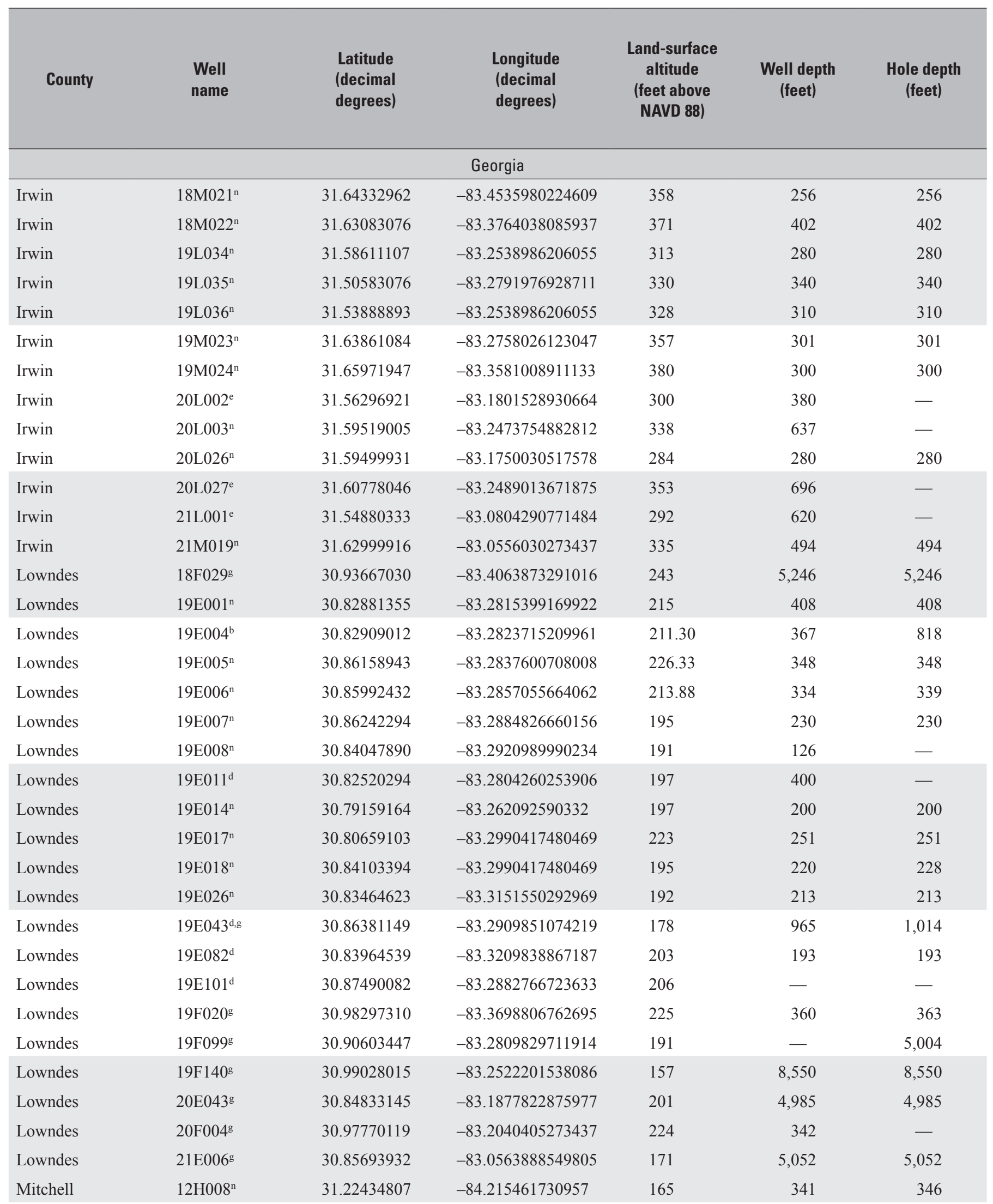


Table A-1. Geohydrologic data for the Aucilla-Suwannee-Ochlockonee River Basin.-Continued

[Accuracy of land-surface altitude varies based on method of measurement. Values reported to hundredths of a foot represent measurement made by surveying or global positioning techniques; - , no data available]

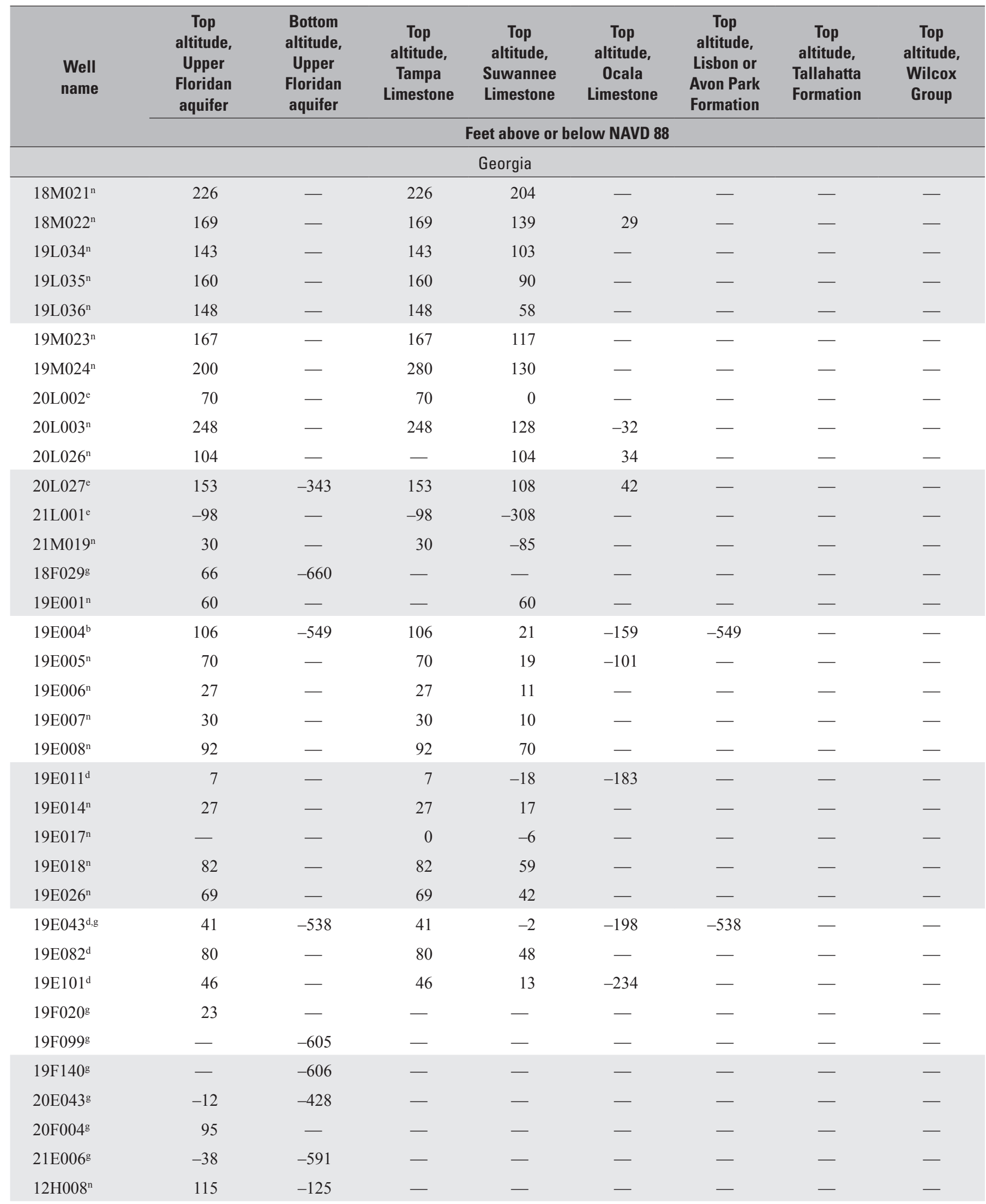


Table A-1. Geohydrologic data for the Aucilla-Suwannee-Ochlockonee River Basin._-Continued

[Accuracy of land-surface altitude varies based on method of measurement. Values reported to hundredths of a foot represent measurement made by surveying or global positioning techniques; - , no data available]

\begin{tabular}{|c|c|c|c|c|c|c|}
\hline County & $\begin{array}{l}\text { Well } \\
\text { name }\end{array}$ & $\begin{array}{l}\text { Latitude } \\
\text { (decimal } \\
\text { degrees) }\end{array}$ & $\begin{array}{l}\text { Longitude } \\
\text { (decimal } \\
\text { degrees) }\end{array}$ & $\begin{array}{l}\text { Land-surface } \\
\text { altitude } \\
\text { (feet above } \\
\text { NAVD 88) }\end{array}$ & $\begin{array}{l}\text { Well depth } \\
\text { (feet) }\end{array}$ & $\begin{array}{l}\text { Hole depth } \\
\text { (feet) }\end{array}$ \\
\hline \multicolumn{7}{|c|}{ Georgia } \\
\hline Mitchell & $13 \mathrm{~J} 003^{\mathrm{n}}$ & 31.26296043 & -84.0210113525391 & 372 & 575 & 575 \\
\hline Mitchell & $13 \mathrm{~J} 009^{\mathrm{n}}$ & 31.32250023 & -84.053337097168 & 272 & 497 & 497 \\
\hline Mitchell & $13 \mathrm{~J} 010^{\mathrm{n}}$ & 31.32268143 & -84.0532379150391 & 270 & 43 & 48 \\
\hline Mitchell & $13 \mathrm{~J} 012^{\mathrm{n}}$ & 31.30624962 & -84.0525817871094 & 287 & - & - \\
\hline Thomas & $10 \mathrm{G} 314^{\mathrm{n}}$ & 31.11244392 & -84.4037475585937 & 140 & 370 & 370 \\
\hline Thomas & $13 \mathrm{E} 002^{\mathrm{e}}$ & 30.96722221 & -84.0430526733398 & 264 & 423 & 423 \\
\hline Thomas & $13 \mathrm{E} 010^{\mathrm{f}}$ & 30.75297165 & -84.0265579223633 & 195 & 204 & - \\
\hline Thomas & $13 \mathrm{~F} 019^{\mathrm{e}}$ & 30.88352394 & -84.0535049438477 & 228 & 240 & - \\
\hline Thomas & $13 \mathrm{~F} 023^{\mathrm{e}}$ & 30.99963188 & -84.1187896728516 & 275 & 408 & - \\
\hline Thomas & $13 \mathrm{~F} 024^{\mathrm{g}}$ & 30.98685455 & -84.0774002075195 & 230 & 446 & - \\
\hline Thomas & $13 \mathrm{~F} 025^{\mathrm{f}}$ & 30.97111130 & -84.0511093139648 & 271 & 637 & 637 \\
\hline Thomas & $13 \mathrm{G} 003^{\mathrm{e}}$ & 31.04129791 & -84.0696182250977 & 304 & 905 & - \\
\hline Thomas & $14 \mathrm{~F} 015^{\mathrm{e}, \mathrm{g}}$ & 30.92435646 & -83.9712829589844 & 238 & 325 & - \\
\hline Thomas & $15 \mathrm{E} 017^{\mathrm{f}}$ & 30.81083298 & -83.7563858032227 & 205 & 904 & 904 \\
\hline Thomas & $15 \mathrm{~F} 016^{\mathrm{f}}$ & 30.98916626 & -83.8088912963867 & 238 & 1,206 & 1,206 \\
\hline Thomas & $15 \mathrm{G} 011^{\mathrm{e}, \mathrm{g}}$ & 31.01157761 & -83.8685073852539 & 252 & 383 & 385 \\
\hline Thomas & $15 \mathrm{G} 043^{\mathrm{g}}$ & 31.00194359 & -83.8272247314453 & 248 & 801 & 801 \\
\hline Tift & $15 \mathrm{~K} 021^{\mathrm{a}, \mathrm{b}}$ & 31.45750046 & -83.8333282470703 & 355 & 585 & 585 \\
\hline Tift & $16 \mathrm{~J} 005^{\mathrm{e}}$ & 31.35833359 & -83.6483306884766 & 295 & - & - \\
\hline Tift & $16 \mathrm{~J} 031^{\mathrm{n}}$ & 31.33416748 & -83.6399993896484 & 273 & 1,170 & 1,170 \\
\hline Tift & $16 \mathrm{~K} 010^{\mathrm{c}}$ & 31.38444519 & -83.628059387207 & 325 & 352 & 352 \\
\hline Tift & $17 \mathrm{~J} 004^{\mathrm{f}}$ & 31.33944511 & -83.5936126708984 & 325 & 705 & 705 \\
\hline Tift & $17 \mathrm{~J} 042^{\mathrm{d}, \mathrm{e}}$ & 31.35416603 & -83.5833282470703 & 324 & 490 & 490 \\
\hline Tift & $17 \mathrm{~K} 007^{\mathrm{n}}$ & 31.49333382 & -83.5458297729492 & 332 & 260 & 260 \\
\hline Tift & $17 \mathrm{~K} 038^{\mathrm{c}, \mathrm{e}}$ & 31.48388863 & -83.529167175293 & 392 & 500 & 500 \\
\hline Tift & $17 \mathrm{~K} 111^{\mathrm{n}}$ & 31.44444466 & -83.5930557250977 & 338 & 350 & 350 \\
\hline
\end{tabular}


Table A-1. Geohydrologic data for the Aucilla-Suwannee-Ochlockonee River Basin.-Continued

[Accuracy of land-surface altitude varies based on method of measurement. Values reported to hundredths of a foot represent measurement made by surveying or global positioning techniques; - , no data available]

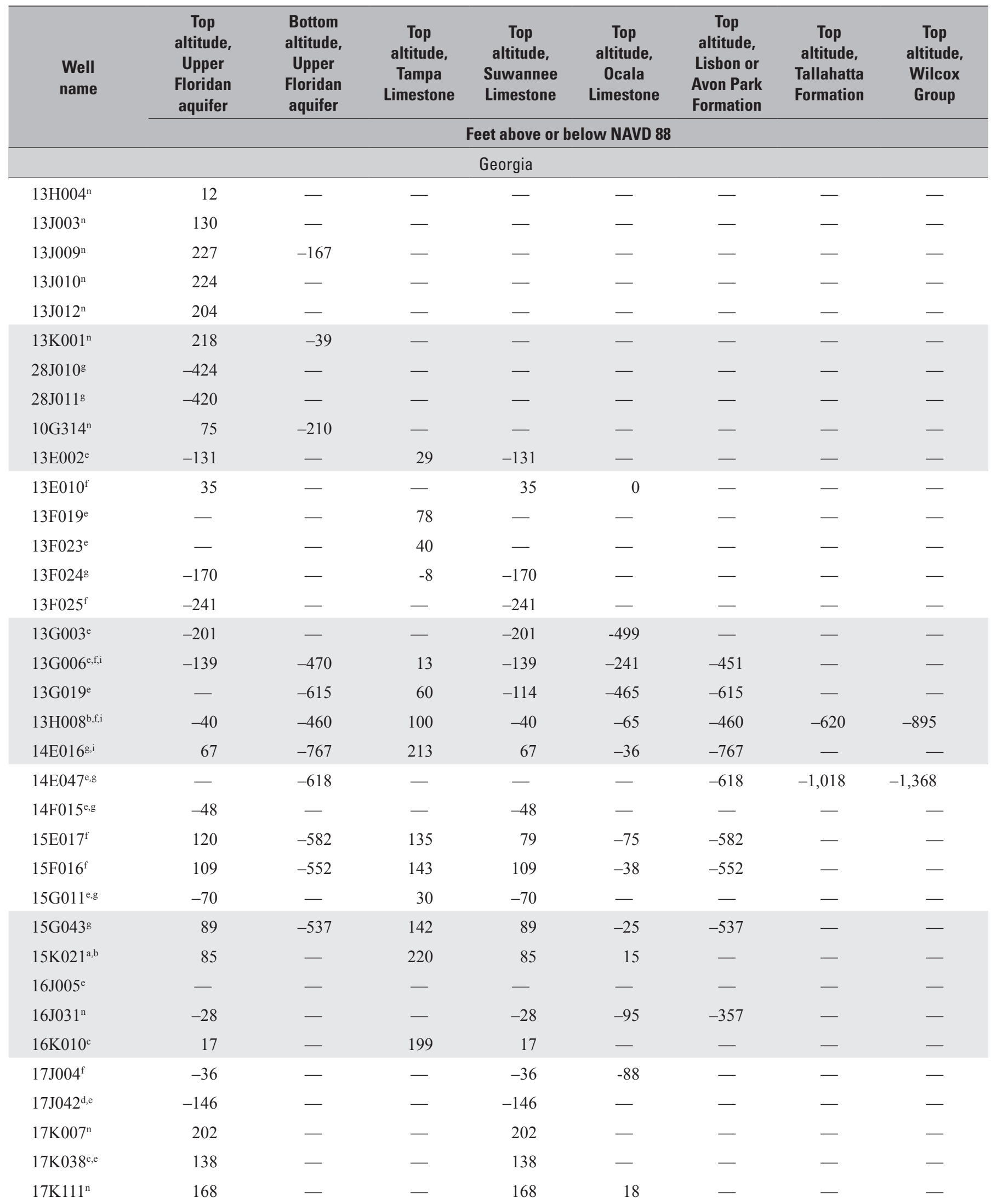


Table A-1. Geohydrologic data for the Aucilla-Suwannee-Ochlockonee River Basin._-Continued

[Accuracy of land-surface altitude varies based on method of measurement. Values reported to hundredths of a foot represent measurement made by surveying or global positioning techniques; - , no data available]

\begin{tabular}{|c|c|c|c|c|c|c|}
\hline County & $\begin{array}{l}\text { Well } \\
\text { name }\end{array}$ & $\begin{array}{l}\text { Latitude } \\
\text { (decimal } \\
\text { degrees) }\end{array}$ & $\begin{array}{l}\text { Longitude } \\
\text { (decimal } \\
\text { degrees) }\end{array}$ & $\begin{array}{l}\text { Land-surface } \\
\text { altitude } \\
\text { (feet above } \\
\text { NAVD 88) }\end{array}$ & $\begin{array}{l}\text { Well depth } \\
\text { (feet) }\end{array}$ & $\begin{array}{l}\text { Hole depth } \\
\text { (feet) }\end{array}$ \\
\hline \multicolumn{7}{|c|}{ Georgia } \\
\hline Tift & $17 \mathrm{~L} 002^{\mathrm{n}}$ & 31.50416756 & -83.5016632080078 & 390 & 350 & 350 \\
\hline Tift & $17 \mathrm{LO03}^{\mathrm{n}}$ & 31.50333405 & -83.5430526733398 & 350 & 208 & 208 \\
\hline Tift & $17 \mathrm{~L} 004^{\mathrm{n}}$ & 31.51861191 & -83.559440612793 & 371 & 260 & 260 \\
\hline Tift & $17 \mathrm{~L} 005^{\mathrm{n}}$ & 31.56944466 & -83.575553894043 & 360 & 170 & 170 \\
\hline Tift & $17 \mathrm{~L} 012^{\mathrm{n}}$ & 31.56212616 & -83.6093368530273 & 311 & 280 & - \\
\hline Tift & $17 \mathrm{~L} 014^{\mathrm{n}}$ & 31.50129509 & -83.6215591430664 & 334 & 250 & - \\
\hline Tift & $17 \mathrm{~L} 015^{\mathrm{n}}$ & 31.51749992 & -83.5663909912109 & 360 & 220 & 220 \\
\hline Tift & $17 \mathrm{~L} 062^{\mathrm{c}, \mathrm{e}}$ & 31.50416756 & -83.5541687011719 & 395 & - & - \\
\hline Tift & $18 \mathrm{~K} 001^{\mathrm{f}}$ & 31.41435242 & -83.4898834228516 & 352 & 610 & - \\
\hline Tift & $18 \mathrm{~K} 003^{\mathrm{n}}$ & 31.54796410 & -83.4537734985352 & 322 & 540 & 一 \\
\hline Tift & $18 \mathrm{~K} 073^{\mathrm{b}, \mathrm{e}}$ & 31.45138931 & -83.4944458007812 & 330 & 501 & 501 \\
\hline Tift & $18 \mathrm{~L} 006^{\mathrm{n}}$ & 31.50333405 & -83.4225006103516 & 320 & 250 & 250 \\
\hline Turner & $16 \mathrm{M} 010^{\mathrm{n}}$ & 31.70517921 & -83.6565551757812 & 430 & 485 & - \\
\hline Turner & $16 \mathrm{M} 011^{\mathrm{n}}$ & 31.70656967 & -83.6546096801758 & 430 & 648 & - \\
\hline Turner & $16 \mathrm{M} 013^{\mathrm{b}}$ & 31.69712448 & -83.6465606689453 & 430 & 650 & - \\
\hline Turner & $16 \mathrm{M} 020^{\mathrm{n}}$ & 31.67818832 & -83.6387329101562 & 404 & 501 & - \\
\hline Turner & $16 \mathrm{M} 021^{\mathrm{b}}$ & 31.69545746 & -83.640998840332 & 402 & 770 & 770 \\
\hline Turner & $16 \mathrm{M} 022^{\mathrm{n}}$ & 31.67073631 & -83.636833190918 & 380 & 525 & 525 \\
\hline Turner & $16 \mathrm{M} 052^{\mathrm{n}}$ & 31.66500092 & -83.7344436645508 & 370 & 320 & 320 \\
\hline Turner & $16 \mathrm{M} 053^{\mathrm{n}}$ & 31.62833405 & -83.7186126708984 & 390 & 240 & 240 \\
\hline Turner & $16 \mathrm{M} 054^{\mathrm{n}}$ & 31.63611031 & -83.7236099243164 & 402 & 402 & 402 \\
\hline Turner & $16 \mathrm{M} 055^{\mathrm{n}}$ & 31.66861153 & -83.6324996948242 & 388 & 250 & 250 \\
\hline Turner & $16 \mathrm{M} 056^{\mathrm{n}}$ & 31.66444397 & -83.7291641235352 & 395 & 270 & 270 \\
\hline Turner & $16 \mathrm{~N} 015^{\mathrm{n}}$ & 31.75305557 & -83.6816635131836 & 386 & 225 & 225 \\
\hline Turner & $16 \mathrm{~N} 016^{\mathrm{n}}$ & 31.75138855 & -83.6630554199219 & 360.38 & 565 & 565 \\
\hline Turner & $17 \mathrm{L008}{ }^{\mathrm{n}}$ & 31.61018181 & -83.5437774658203 & 352 & 220 & - \\
\hline
\end{tabular}


Table A-1. Geohydrologic data for the Aucilla-Suwannee-Ochlockonee River Basin.-Continued

[Accuracy of land-surface altitude varies based on method of measurement. Values reported to hundredths of a foot represent measurement made by surveying or global positioning techniques; - , no data available]

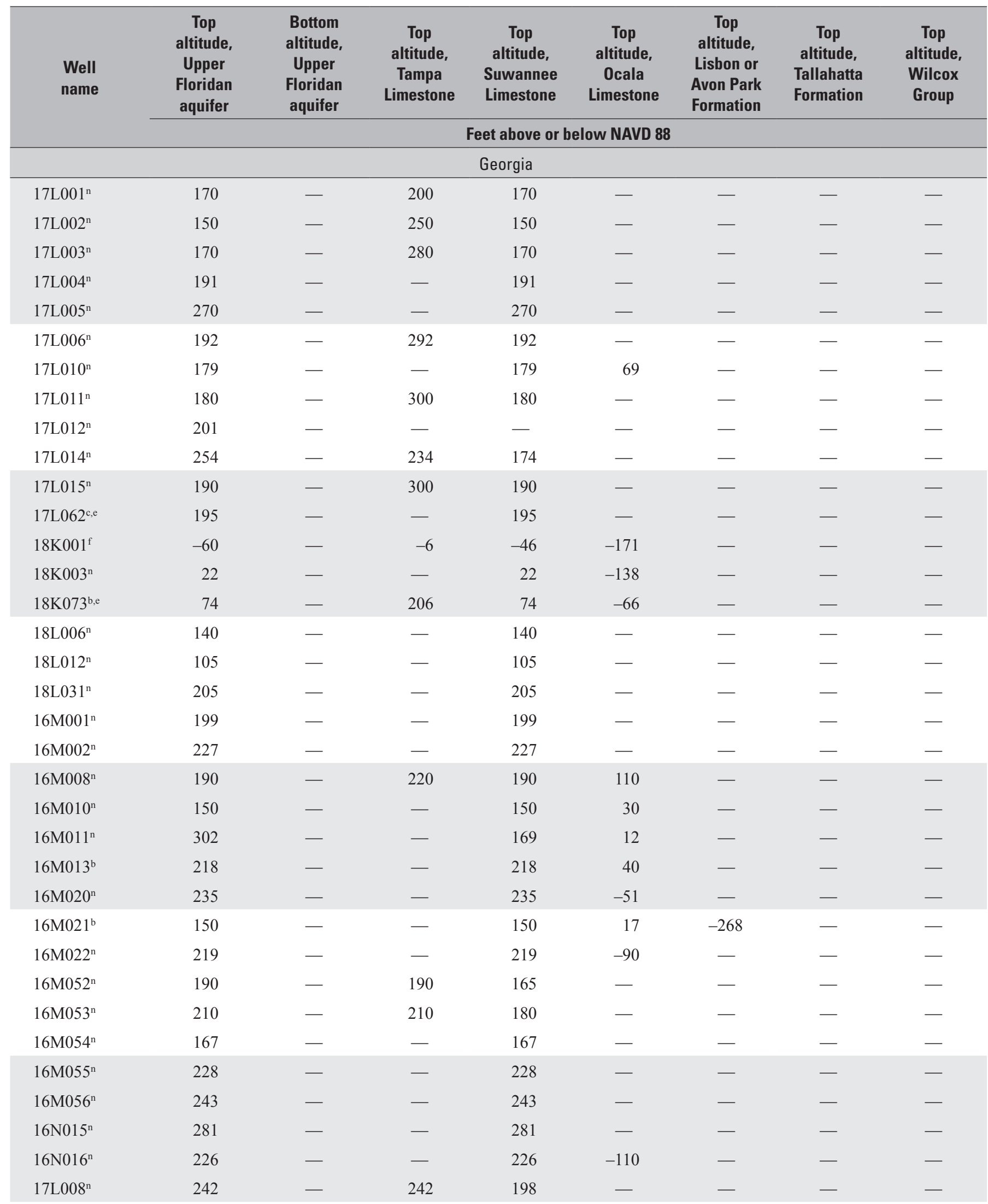


Table A-1. Geohydrologic data for the Aucilla-Suwannee-Ochlockonee River Basin._-Continued

[Accuracy of land-surface altitude varies based on method of measurement. Values reported to hundredths of a foot represent measurement made by surveying or global positioning techniques; - , no data available]

\begin{tabular}{|c|c|c|c|c|c|c|}
\hline County & $\begin{array}{l}\text { Well } \\
\text { name }\end{array}$ & $\begin{array}{l}\text { Latitude } \\
\text { (decimal } \\
\text { degrees) }\end{array}$ & $\begin{array}{l}\text { Longitude } \\
\text { (decimal } \\
\text { degrees) }\end{array}$ & $\begin{array}{l}\text { Land-surface } \\
\text { altitude } \\
\text { (feet above } \\
\text { NAVD 88) }\end{array}$ & $\begin{array}{l}\text { Well depth } \\
\text { (feet) }\end{array}$ & $\begin{array}{l}\text { Hole depth } \\
\text { (feet) }\end{array}$ \\
\hline \multicolumn{7}{|c|}{ Georgia } \\
\hline Turner & $17 \mathrm{~L} 063^{\mathrm{n}}$ & 31.60916710 & -83.5749969482422 & 325 & 130 & 130 \\
\hline Turner & $17 \mathrm{~L} 064^{\mathrm{n}}$ & 31.59722137 & -83.5963897705078 & 358 & 260 & 260 \\
\hline Turner & $17 \mathrm{~L} 065^{\mathrm{n}}$ & 31.61305618 & -83.5008316040039 & 330 & 336 & 336 \\
\hline Turner & $17 \mathrm{M} 007^{\mathrm{n}}$ & 31.71462440 & -83.5712738037109 & 382 & 242 & - \\
\hline Turner & $17 \mathrm{M} 047^{\mathrm{n}}$ & 31.67138863 & -83.5919418334961 & 400 & 235 & 235 \\
\hline Turner & $17 \mathrm{M} 048^{\mathrm{n}}$ & 31.63972282 & -83.616943359375 & 385 & 250 & 250 \\
\hline Turner & $17 \mathrm{~N} 001^{\mathrm{n}}$ & 31.78573608 & -83.5073852539062 & 382 & 194 & 194 \\
\hline Turner & $17 \mathrm{~N} 002^{\mathrm{n}}$ & 31.81323433 & -83.6007232666016 & 365 & 51 & 260 \\
\hline Turner & $18 \mathrm{~N} 011^{\mathrm{n}}$ & 31.83555603 & -83.4974975585937 & 351 & 220 & 220 \\
\hline Turner & $18 \mathrm{~N} 012^{\mathrm{n}}$ & 31.82250023 & -83.4888916015625 & 350 & 176 & 176 \\
\hline Turner & $33 \mathrm{H} 016^{\mathrm{n}}$ & 31.12717438 & -81.5550994873047 & 365 & 780 & 780 \\
\hline Ware & $24 \mathrm{P} 010^{\mathrm{g}}$ & 31.97972298 & -82.6466674804687 & 121 & 701 & 701 \\
\hline Wilcox & $17 \mathrm{P} 012^{\mathrm{n}}$ & 31.92861176 & -83.5008316040039 & 365 & 175 & 175 \\
\hline Wilcox & $17 \mathrm{P} 013^{\mathrm{n}}$ & 31.96361160 & -83.5663909912109 & 372 & 225 & 225 \\
\hline Wilcox & 17Q0201 & 32.11294937 & -83.5037841796875 & 273 & 293 & 293 \\
\hline Wilcox & $17 \mathrm{Q} 021^{1}$ & 32.10972214 & -83.5038909912109 & 278 & 210 & 210 \\
\hline Wilcox & $18 \mathrm{P} 001^{\mathrm{b}, \mathrm{g}}$ & 31.95045471 & -83.4576644897461 & 367 & 335 & - \\
\hline Wilcox & $18 \mathrm{P} 006^{\mathrm{n}}$ & 31.97888947 & -83.4944458007812 & 415 & 255 & 255 \\
\hline Wilcox & $20 \mathrm{~N} 005^{\mathrm{n}}$ & 31.84851646 & -83.2082061767578 & 167 & 642 & - \\
\hline Wilcox & $20 \mathrm{~N} 010^{\mathrm{n}}$ & 31.86722183 & -83.2286148071289 & 292 & 173 & 173 \\
\hline Wilcox & $20 \mathrm{~N} 017^{\mathrm{n}}$ & 31.84693909 & -83.2133026123047 & 170 & - & - \\
\hline Worth & $14 \mathrm{~J} 003^{\mathrm{n}}$ & 31.33490372 & -83.9640655517578 & 382 & 280 & 280 \\
\hline Worth & $14 \mathrm{~J} 006^{\mathrm{c}}$ & 31.37138939 & -83.9397201538086 & 412 & 250 & 250 \\
\hline Worth & $14 \mathrm{~K} 001^{\mathrm{f}}$ & 31.44434738 & -83.8782348632812 & 430 & 454 & 454 \\
\hline Worth & $14 \mathrm{~K} 003^{\mathrm{n}}$ & 31.46351242 & -83.9149017333984 & 431 & 370 & 370 \\
\hline Worth & $14 \mathrm{~K} 005^{\mathrm{e}}$ & 31.40768051 & -83.9662933349609 & 409 & - & 280 \\
\hline
\end{tabular}


Table A-1. Geohydrologic data for the Aucilla-Suwannee-Ochlockonee River Basin.-Continued

[Accuracy of land-surface altitude varies based on method of measurement. Values reported to hundredths of a foot represent measurement made by surveying or global positioning techniques; - , no data available]

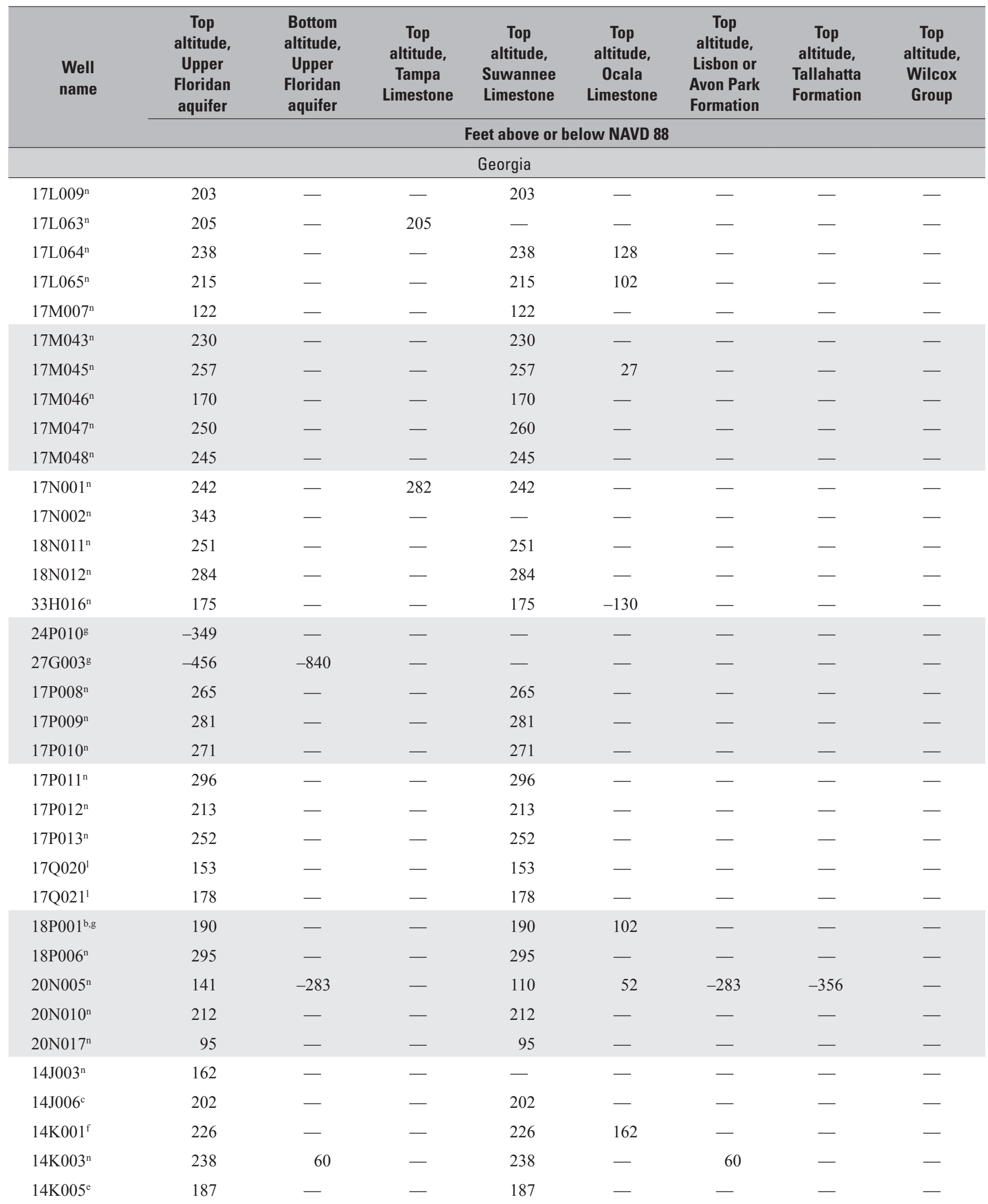


Table A-1. Geohydrologic data for the Aucilla-Suwannee-0chlockonee River Basin.—Continued

[Accuracy of land-surface altitude varies based on method of measurement. Values reported to hundredths of a foot represent measurement made by surveying or global positioning techniques; - , no data available]

\begin{tabular}{|c|c|c|c|c|c|c|}
\hline County & $\begin{array}{l}\text { Well } \\
\text { name }\end{array}$ & $\begin{array}{l}\text { Latitude } \\
\text { (decimal } \\
\text { degrees) }\end{array}$ & $\begin{array}{l}\text { Longitude } \\
\text { (decimal } \\
\text { degrees) }\end{array}$ & $\begin{array}{l}\text { Land-surface } \\
\text { altitude } \\
\text { (feet above } \\
\text { NAVD 88) }\end{array}$ & $\begin{array}{l}\text { Well depth } \\
\text { (feet) }\end{array}$ & $\begin{array}{l}\text { Hole depth } \\
\text { (feet) }\end{array}$ \\
\hline \multicolumn{7}{|c|}{ Georgia } \\
\hline Worth & $14 \mathrm{~K} 053^{\mathrm{n}}$ & 31.40830612 & -83.9116363525391 & 385 & 500 & 600 \\
\hline Worth & $14 \mathrm{~K} 054^{\mathrm{n}}$ & 31.49323273 & -83.9615707397461 & 315 & 465 & 465 \\
\hline Worth & $14 \mathrm{~K} 055^{\mathrm{n}}$ & 31.49323273 & -83.9615707397461 & 315 & 83 & 87 \\
\hline Worth & $14 \mathrm{~K} 058^{\mathrm{n}}$ & 31.49323082 & -83.9615707397461 & 315 & - & - \\
\hline Worth & $14 \mathrm{~L} 002^{\mathrm{c}, \mathrm{e}}$ & 31.54990005 & -83.8776779174805 & 430 & 460 & 460 \\
\hline Worth & $14 \mathrm{~L} 003^{\mathrm{b}, \mathrm{e}}$ & 31.58350945 & -83.9407348632812 & 335 & - & 315 \\
\hline Worth & $14 \mathrm{~L} 007^{\mathrm{e}}$ & 31.55156708 & -83.9162902832031 & 355 & 180 & 180 \\
\hline Worth & $14 \mathrm{~L} 009^{\mathrm{n}}$ & 31.58323288 & -83.9182357788086 & 288 & 238 & 238 \\
\hline Worth & $14 \mathrm{~L} 012^{\mathrm{n}}$ & 31.55073357 & -83.9212875366211 & 355 & - & - \\
\hline Worth & $14 \mathrm{~L} 030^{\mathrm{n}}$ & 31.54601097 & -83.8818435668945 & 390 & - & 214 \\
\hline Worth & $14 \mathrm{M} 001^{\mathrm{n}}$ & 31.64295387 & -83.9157333374023 & 263 & 215 & 215 \\
\hline Worth & $14 \mathrm{M} 008^{\mathrm{n}}$ & 31.71850967 & -83.888786315918 & 289 & 102 & 102 \\
\hline Worth & $14 \mathrm{~N} 001^{\mathrm{n}}$ & 31.82795143 & -83.9218444824219 & 278 & 325 & 325 \\
\hline Worth & $14 \mathrm{~N} 014^{\mathrm{n}}$ & 31.76055527 & -83.9191665649414 & 250 & 110 & 110 \\
\hline Worth & $15 \mathrm{~J} 015^{\mathrm{e}}$ & 31.36518288 & -83.8551788330078 & 400 & - & 320 \\
\hline Worth & $15 \mathrm{~J} 017^{\mathrm{b}, \mathrm{e}}$ & 31.37240410 & -83.8551788330078 & 412 & - & 300 \\
\hline Worth & $15 \mathrm{~K} 003^{\mathrm{n}}$ & 31.43934822 & -83.818229675293 & 391 & - & 240 \\
\hline Worth & $15 \mathrm{~K} 004^{\mathrm{g}}$ & 31.37879372 & -83.7987899780273 & 348 & - & 802 \\
\hline Worth & $15 \mathrm{~L} 004^{\mathrm{f}}$ & 31.58934593 & -83.8435134887695 & 412 & 402 & 402 \\
\hline Worth & $15 \mathrm{~L} 005^{\mathrm{n}}$ & 31.51823616 & -83.8193435668945 & 380 & 178 & 178 \\
\hline Worth & $15 \mathrm{~L} 020^{\mathrm{n}}$ & 31.52962494 & -83.8210067749023 & 420 & 450 & 738 \\
\hline Worth & $15 \mathrm{~L} 021^{\mathrm{n}}$ & 31.53767967 & -83.8457336425781 & 380 & 536 & 536 \\
\hline Worth & $15 \mathrm{~L} 032^{\mathrm{n}}$ & 31.59055519 & -83.8383331298828 & 410 & 520 & 520 \\
\hline Worth & $15 \mathrm{~L} 035^{\mathrm{n}}$ & 31.58936119 & -83.836669921875 & 410 & 430 & 430 \\
\hline Worth & $15 \mathrm{~N} 003^{\mathrm{n}}$ & 31.80775070 & -83.8363037109375 & 285 & 50 & 57 \\
\hline Worth & $15 \mathrm{~N} 005^{\mathrm{n}}$ & 31.80805588 & -83.8363876342773 & 281 & 260 & 260 \\
\hline Worth & $15 \mathrm{~N} 006^{\mathrm{n}}$ & 31.80791664 & -83.8323059082031 & 288 & 210 & 210 \\
\hline Worth & $16 \mathrm{~J} 030^{\mathrm{e}}$ & 31.32028008 & -83.7375030517578 & 288 & 5,568 & 5,568 \\
\hline Worth & $16 \mathrm{~J} 047^{\mathrm{e}}$ & 31.35472298 & -83.6972198486328 & 340 & 440 & 440 \\
\hline Worth & $16 \mathrm{~K} 011^{\mathrm{e}}$ & 31.40157127 & -83.7037811279297 & 362 & 620 & - \\
\hline Worth & $16 \mathrm{~K} 013^{\mathrm{e}}$ & 31.42407227 & -83.7096176147461 & 375 & 610 & - \\
\hline Worth & $16 \mathrm{~L} 011^{\mathrm{e}}$ & 31.55073547 & -83.7746200561523 & 332 & 210 & - \\
\hline Worth & $16 \mathrm{~L} 019^{\mathrm{n}}$ & 31.51268196 & -83.7382278442383 & 380 & - & 717 \\
\hline
\end{tabular}


Table A-1. Geohydrologic data for the Aucilla-Suwannee-0chlockonee River Basin.-Continued

[Accuracy of land-surface altitude varies based on method of measurement. Values reported to hundredths of a foot represent measurement made by surveying or global positioning techniques; - , no data available]

\begin{tabular}{|c|c|c|c|c|c|c|c|c|}
\hline \multirow[t]{2}{*}{$\begin{array}{l}\text { Well } \\
\text { name }\end{array}$} & $\begin{array}{c}\text { Top } \\
\text { altitude, } \\
\text { Upper } \\
\text { Floridan } \\
\text { aquifer }\end{array}$ & $\begin{array}{c}\text { Bottom } \\
\text { altitude, } \\
\text { Upper } \\
\text { Floridan } \\
\text { aquifer }\end{array}$ & $\begin{array}{c}\text { Top } \\
\text { altitude, } \\
\text { Tampa } \\
\text { Limestone }\end{array}$ & $\begin{array}{c}\text { Top } \\
\text { altitude, } \\
\text { Suwannee } \\
\text { Limestone }\end{array}$ & $\begin{array}{c}\text { Top } \\
\text { altitude, } \\
\text { Ocala } \\
\text { Limestone }\end{array}$ & $\begin{array}{c}\text { Top } \\
\text { altitude, } \\
\text { Lisbon or } \\
\text { Avon Park } \\
\text { Formation }\end{array}$ & $\begin{array}{c}\text { Top } \\
\text { altitude, } \\
\text { Tallahatta } \\
\text { Formation }\end{array}$ & $\begin{array}{c}\text { Top } \\
\text { altitude } \\
\text { Wilcox } \\
\text { Group }\end{array}$ \\
\hline & \multicolumn{8}{|c|}{ Feet above or below NAVD 88} \\
\hline \multicolumn{9}{|c|}{ Georgia } \\
\hline $14 \mathrm{~K} 053^{\mathrm{n}}$ & 360 & - & - & 360 & 318 & - & - & - \\
\hline $14 \mathrm{~K} 054^{\mathrm{n}}$ & 210 & -150 & - & - & - & - & - & - \\
\hline $14 \mathrm{~K} 055^{\mathrm{n}}$ & 228 & - & - & - & - & - & - & - \\
\hline $14 \mathrm{~K} 058^{\mathrm{n}}$ & 224 & -145 & - & - & - & - & - & - \\
\hline $14 \mathrm{~L} 002^{\mathrm{c}, \mathrm{e}}$ & 222 & - & - & 222 & 146 & 53 & - & - \\
\hline $14 \mathrm{~L} 003^{\mathrm{b}, \mathrm{e}}$ & 245 & - & - & - & 245 & - & - & - \\
\hline $14 \mathrm{~L} 007^{\mathrm{e}}$ & 285 & - & - & 285 & - & - & - & - \\
\hline $14 \mathrm{~L} 009^{\mathrm{n}}$ & 234 & 56 & - & 234 & 180 & 56 & - & - \\
\hline $14 \mathrm{~L} 012^{\mathrm{n}}$ & - & - & - & - & - & - & - & - \\
\hline $14 \mathrm{~L} 030^{\mathrm{n}}$ & 222 & - & - & 222 & - & - & - & - \\
\hline $14 \mathrm{M} 001^{\mathrm{n}}$ & 119 & - & - & - & - & - & - & - \\
\hline $14 \mathrm{M} 008^{\mathrm{n}}$ & 226 & - & - & 226 & - & - & - & - \\
\hline $14 \mathrm{~N} 001^{\mathrm{n}}$ & 226 & - & - & 226 & 164 & - & - & - \\
\hline $14 \mathrm{~N} 014^{\mathrm{n}}$ & 220 & - & - & 220 & 200 & - & - & - \\
\hline $15 \mathrm{~J} 015^{\mathrm{e}}$ & 100 & - & - & 100 & - & - & - & - \\
\hline $15 \mathrm{~J} 017^{\mathrm{b}, \mathrm{e}}$ & 132 & - & - & 132 & - & - & - & - \\
\hline $15 \mathrm{~K} 003^{\mathrm{n}}$ & 175 & - & - & - & 175 & - & - & - \\
\hline $15 \mathrm{~K} 004^{\mathrm{g}}$ & 96 & -331 & - & 96 & 17 & -331 & -434 & - \\
\hline $15 \mathrm{~L} 004^{\mathrm{f}}$ & 184 & - & - & - & 184 & 25 & - & - \\
\hline $15 \mathrm{~L} 005^{\mathrm{n}}$ & 224 & - & - & 224 & - & - & - & - \\
\hline $15 \mathrm{~L} 020^{\mathrm{n}}$ & 230 & - & - & 230 & - & - & - & - \\
\hline $15 \mathrm{~L} 021^{\mathrm{n}}$ & 250 & -146 & - & - & - & - & - & - \\
\hline $15 \mathrm{~L} 032^{\mathrm{n}}$ & 230 & -100 & - & - & 230 & -100 & - & - \\
\hline $15 \mathrm{~L} 035^{\mathrm{n}}$ & 240 & - & - & - & - & - & - & - \\
\hline $15 \mathrm{~N} 003^{\mathrm{n}}$ & 230 & - & - & - & 230 & - & - & - \\
\hline $15 \mathrm{~N} 005^{\mathrm{n}}$ & 228 & 70 & - & - & - & - & - & - \\
\hline $15 \mathrm{~N} 006^{\mathrm{n}}$ & 248 & - & - & - & 248 & - & - & - \\
\hline $16 \mathrm{~J} 030^{\mathrm{e}}$ & -98 & -718 & - & -98 & - & -718 & - & - \\
\hline $16 \mathrm{~J} 047^{\mathrm{e}}$ & -50 & - & - & -50 & - & - & - & - \\
\hline $16 \mathrm{~K} 011^{\mathrm{e}}$ & 2 & - & - & 2 & - & - & - & - \\
\hline $16 \mathrm{~K} 013^{\mathrm{e}}$ & 1 & - & - & 1 & - & - & - & - \\
\hline $16 \mathrm{~L} 011^{\mathrm{e}}$ & 242 & - & - & 242 & - & - & - & - \\
\hline $16 \mathrm{~L} 019^{\mathrm{n}}$ & - & - & - & -46 & -180 & - & - & - \\
\hline
\end{tabular}


Table A-1. Geohydrologic data for the Aucilla-Suwannee-0chlockonee River Basin.—Continued

\section{Footnotes}

a Applin and Applin, 1964.

${ }^{\mathrm{b}}$ Herrick, 1961.

c Kellam and Gorday, 1990.

d Mcconnell and Hacke, 1993.

e McFadden and others, 1986.

${ }^{\mathrm{f}}$ Miller, 1986.

${ }^{\mathrm{g}}$ Miller, 1988.

${ }^{\mathrm{h}}$ Sever, 1964.

i Sever, 1965.

j Sever, 1966.

${ }^{\mathrm{k}}$ Sever and Herrick, 1967.

${ }^{1}$ Stephenson and Veatch, 1915.

${ }^{\mathrm{m}}$ Torak and Painter, 2006.

${ }^{\mathrm{n}}$ Data on file at the U.S. Geological Survey, Georgia Water Science Center, Atlanta, Georgia. 
Manuscript approved for publication, April 8, 2010

Edited by Kimberly A. Waltenbaugh

Graphics by Bonnie J. Turcott

Layout by Caryl J. Wipperfurth

For more information concerning the research in this report, contact

USGS Georgia Water Science Center

3039 Amwiler Road

Atlanta, Georgia 30360

telephone: $770-903-9100$

http://ga.water.usgs.gov 
